\title{
عادات الحرب عند العرب قبل الإسلام
}

\section{أ.م.د. سعد عبود سمار / جامعة واسط / كلية التربية / قسم التاريخ}

\begin{abstract}
: المقدمة :
\end{abstract}

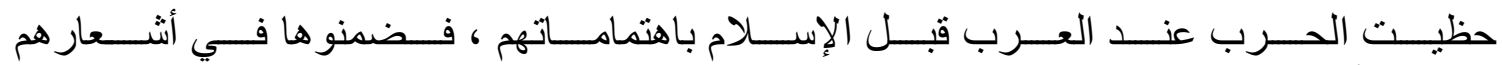

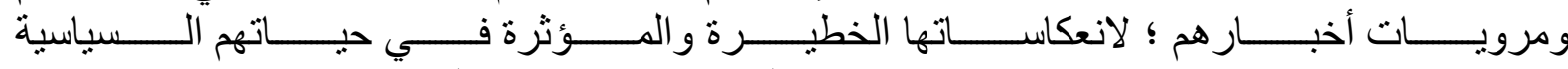

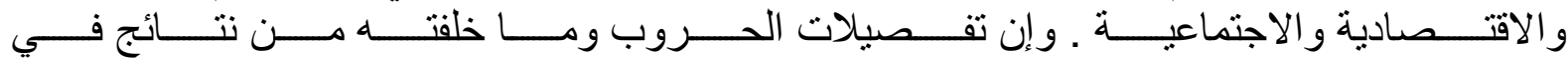

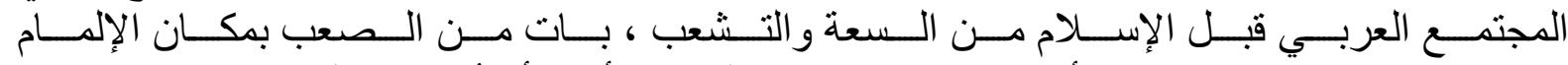

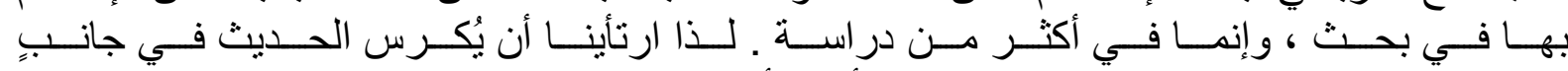

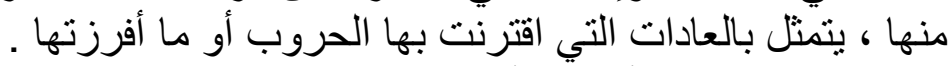

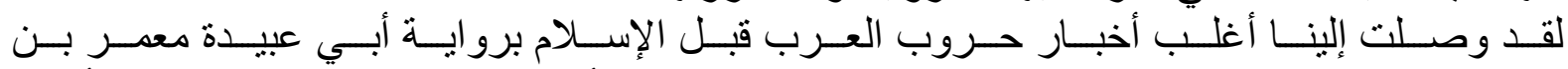

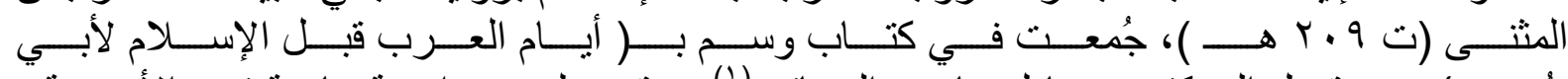

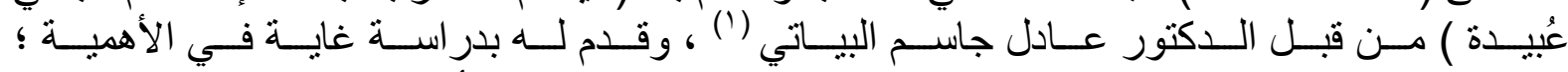

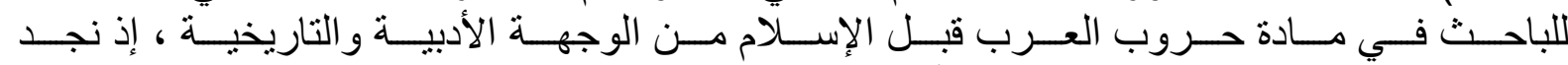

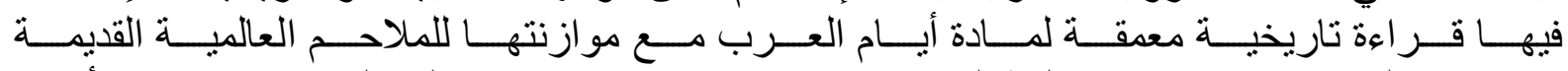

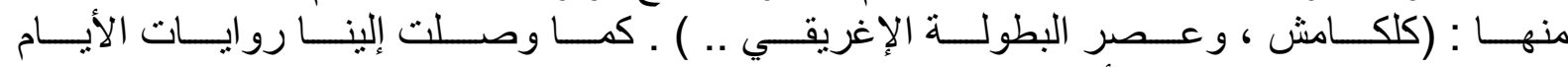

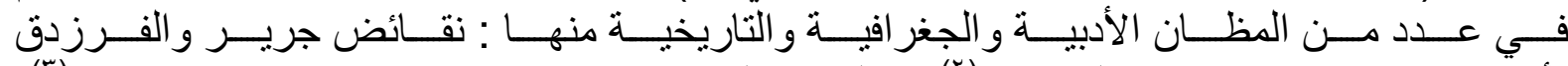

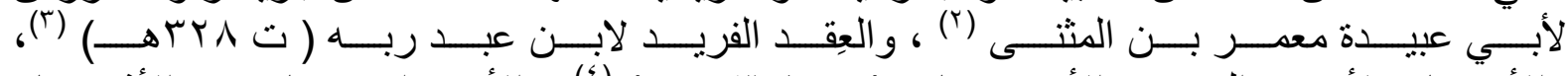

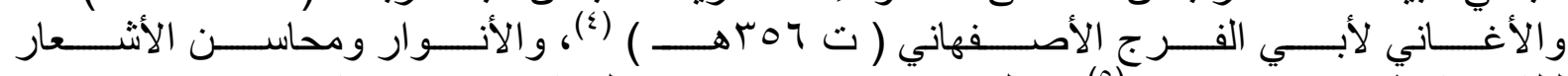

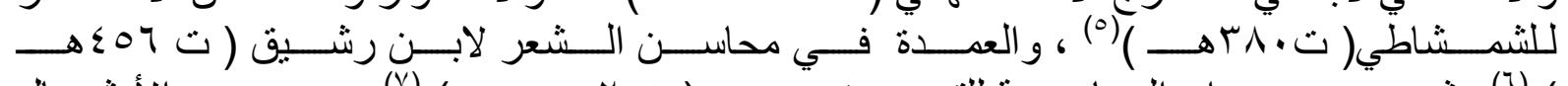

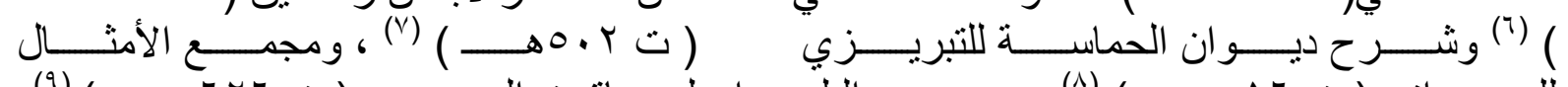

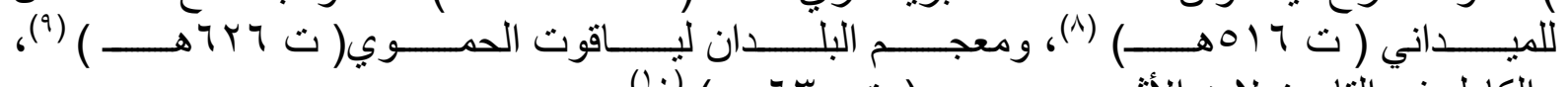

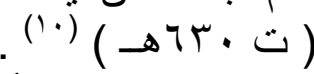
و الكامل في التاريخ لابن الأثثير

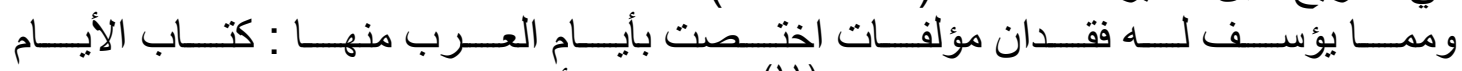

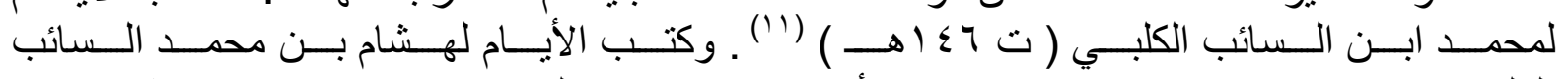

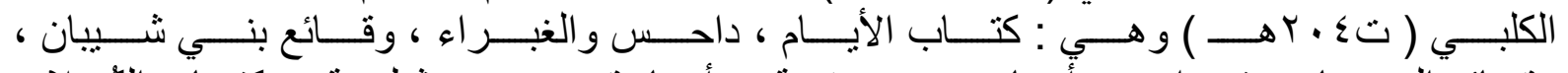

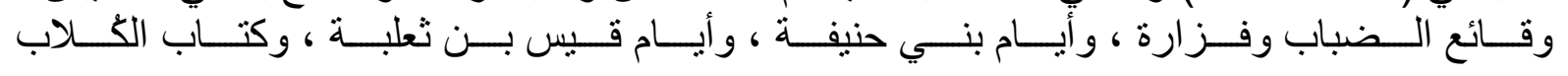

1 - ساعدت جامعة بغداد على نشره ، مطبعة دار الجاحظ ، ( بغداد ، 19 ( ) ) .

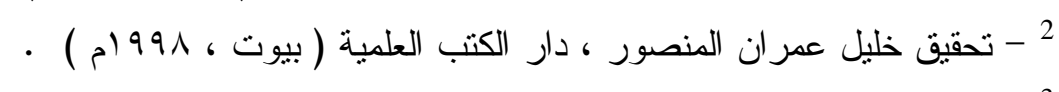
3

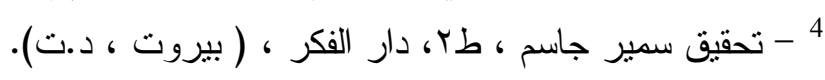

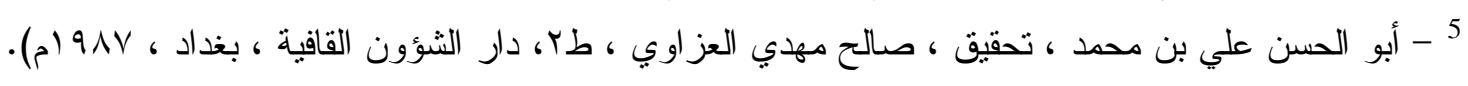

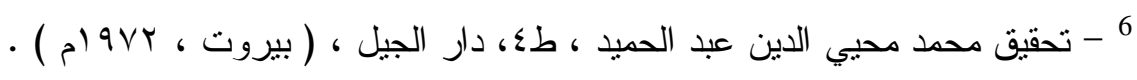

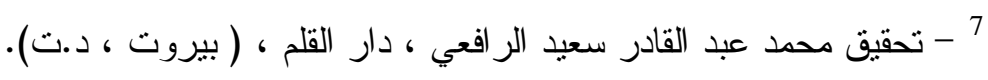

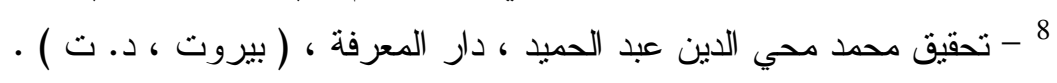
9

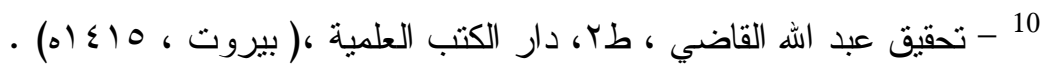

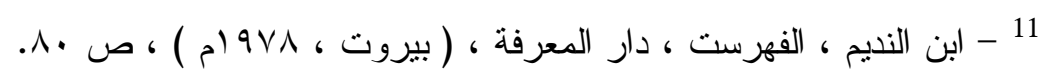




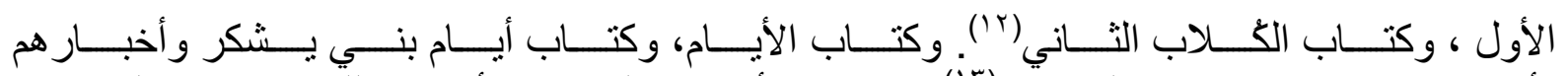

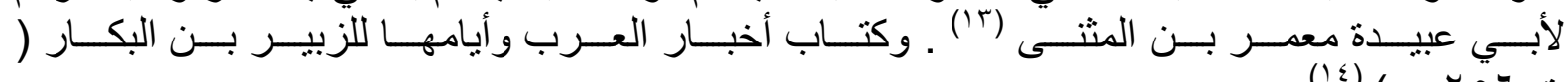

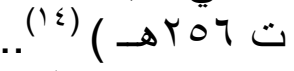

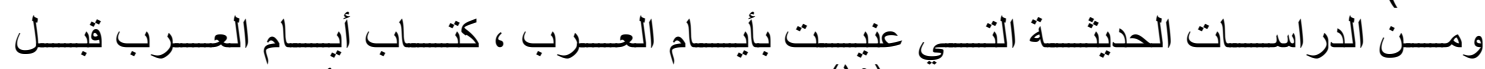

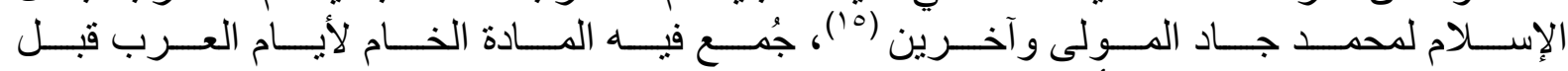

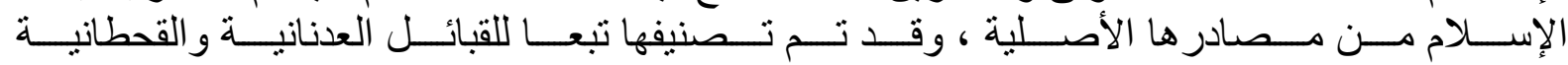

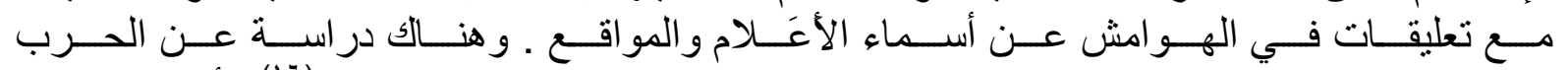

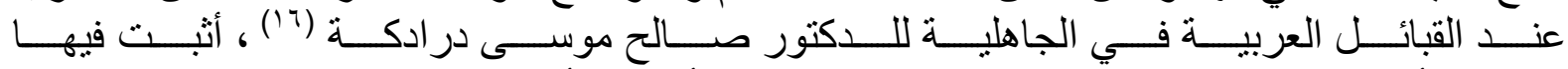

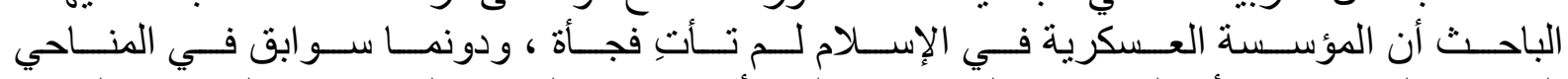

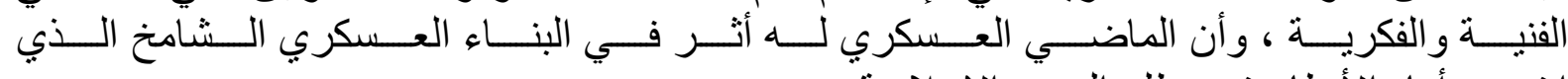

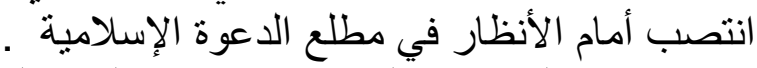

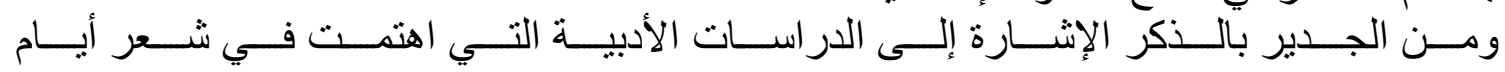

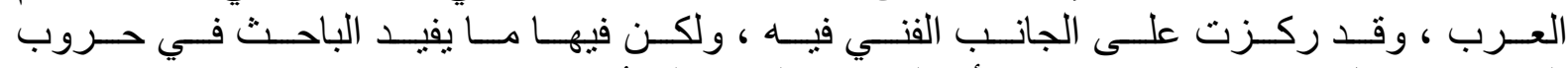

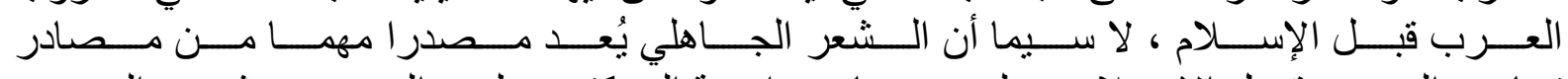

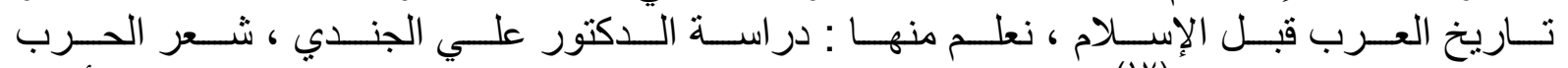

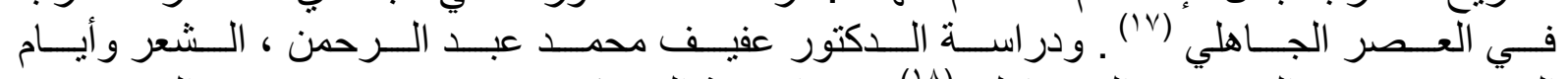

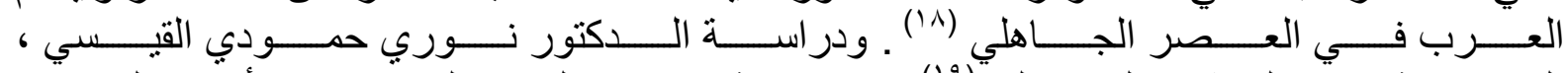

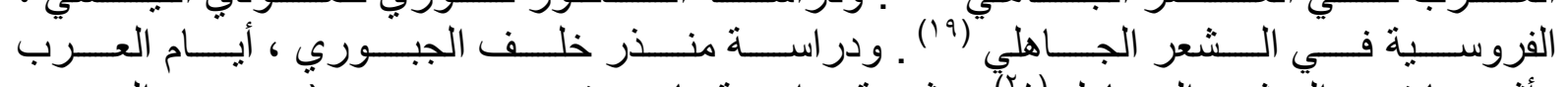

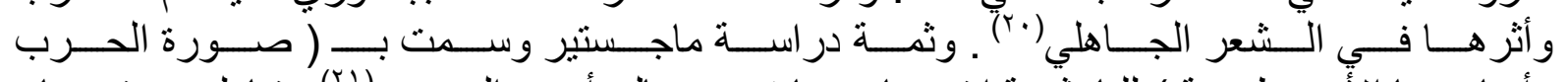

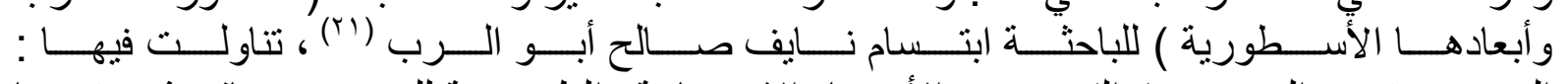

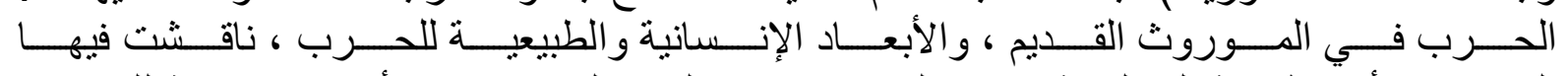

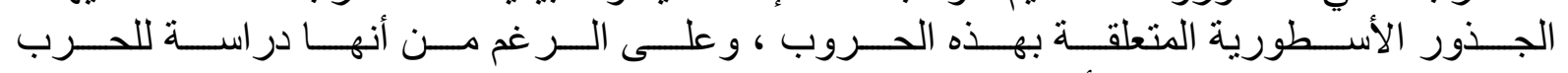

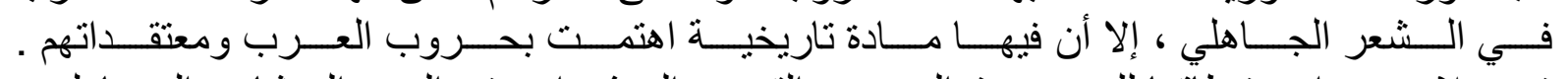

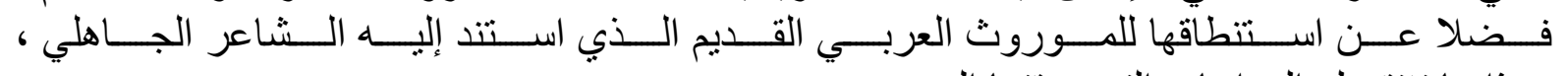

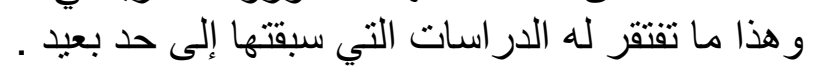

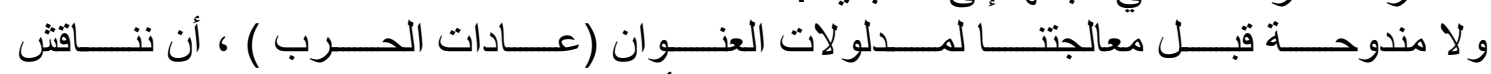

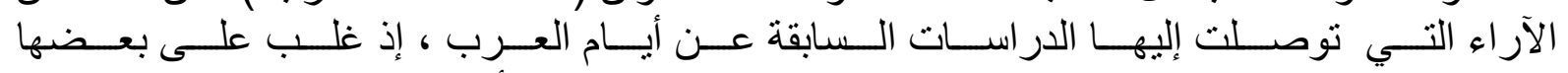

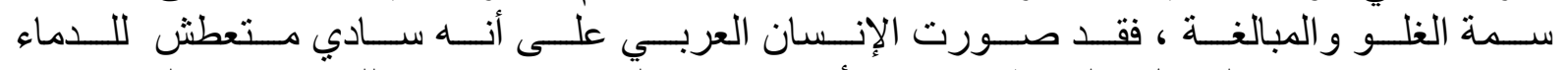

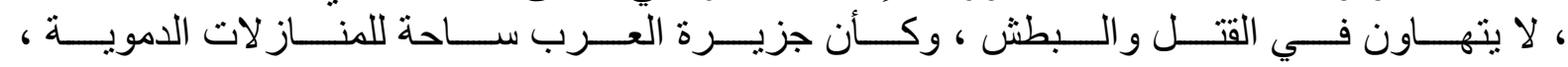

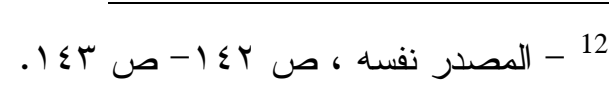

$$
\begin{aligned}
& 13 \\
& 14
\end{aligned}
$$

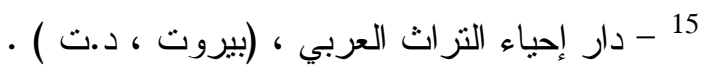

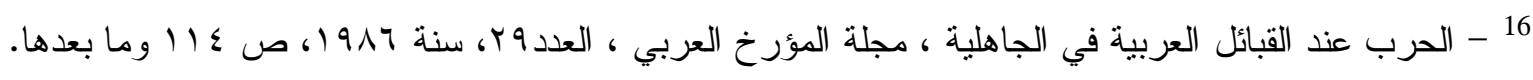
17 18 19

20 21 - مقدمة إلى جامعة النجاح الوطنية في نابلس ، كلية الدراسات العليا ، قسم اللغة العربية وآدابها 7 ـ . بام . 


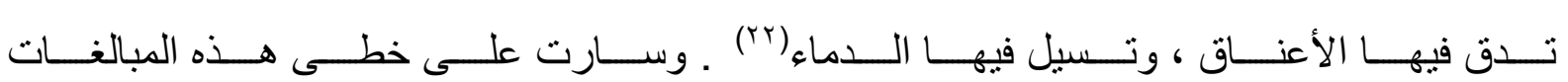

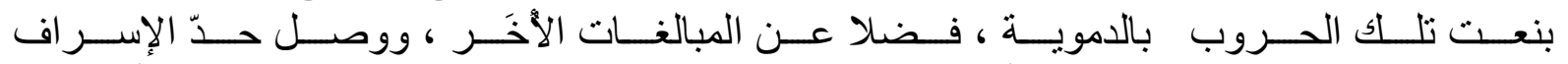

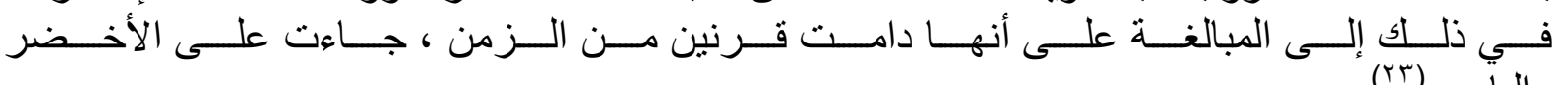

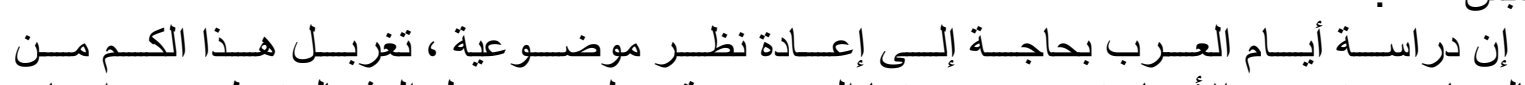

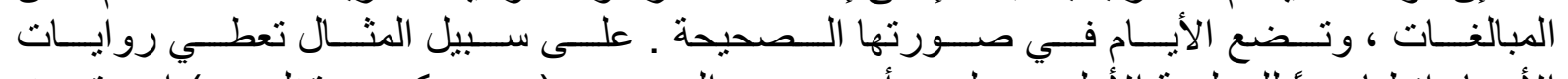

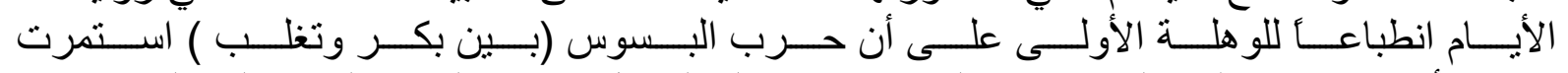

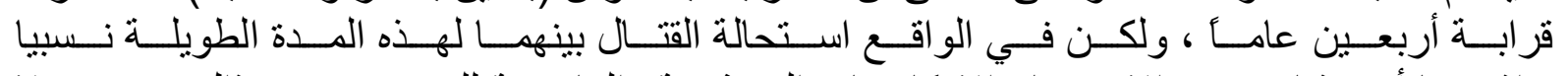

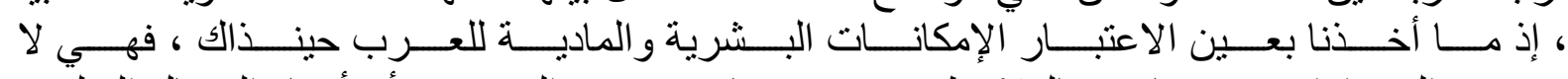

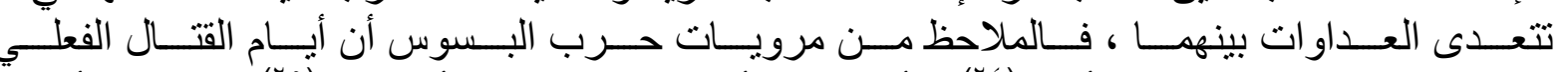

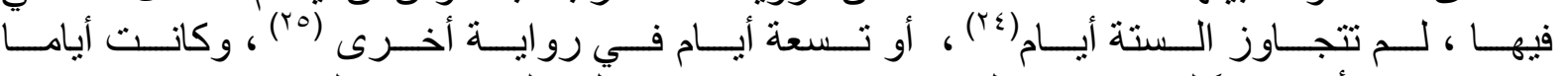

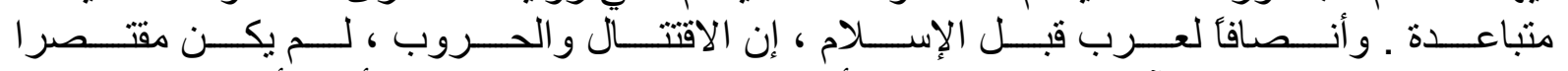

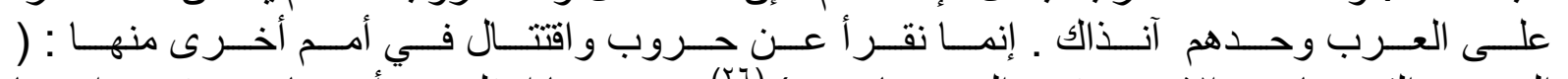

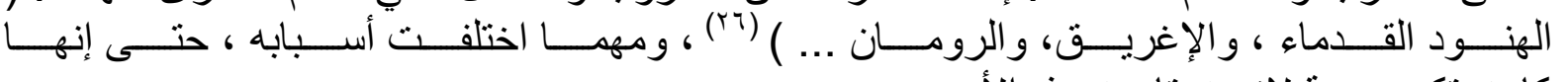

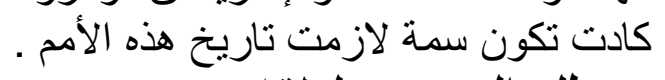

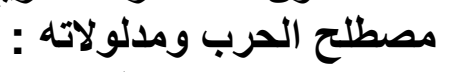

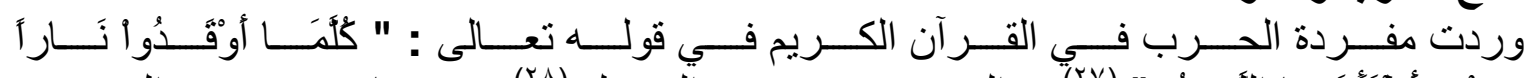

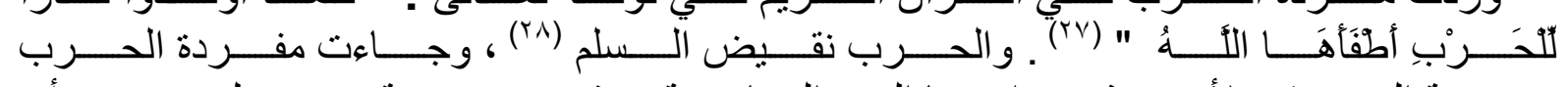

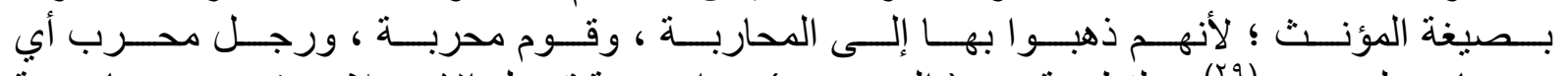

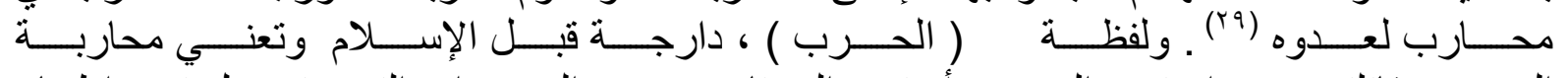

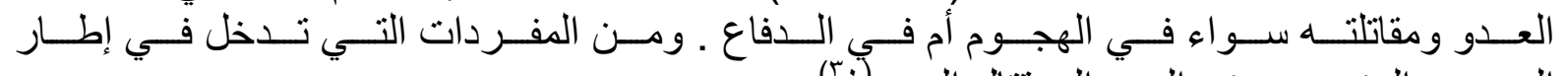

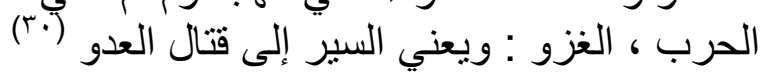

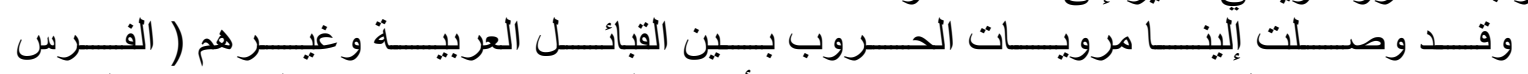

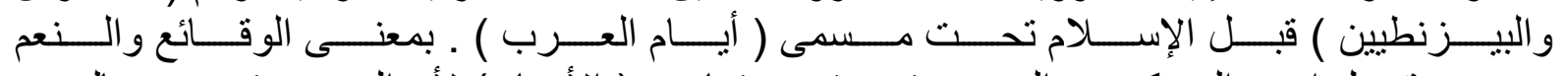

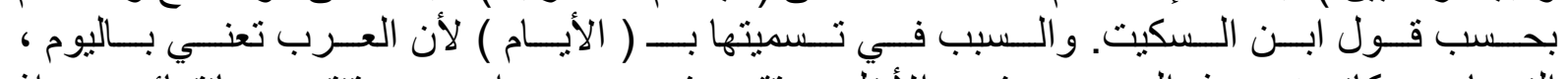

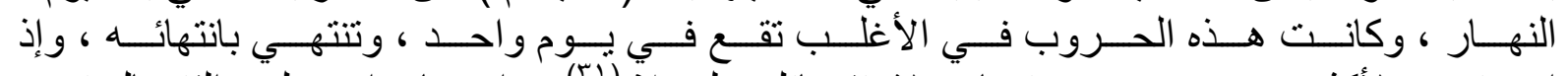

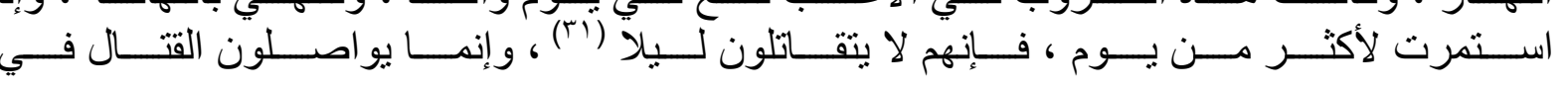

22 - يمثل هذا الر أي : شوقي ضيف ، البطولة في الثعر العربي ، ينظر على سبيل المثال ، ص ص ا.

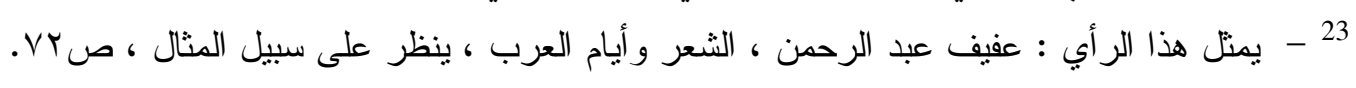

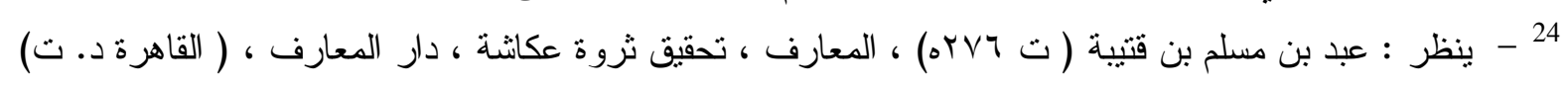

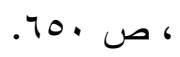
25

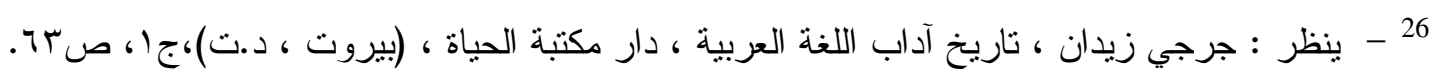
27

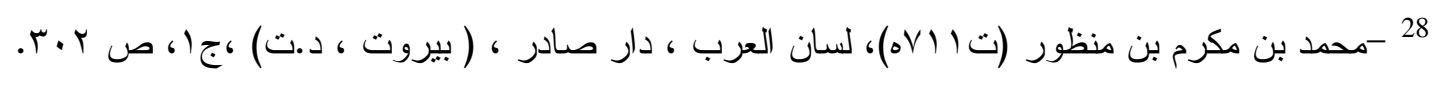
29 30 31 


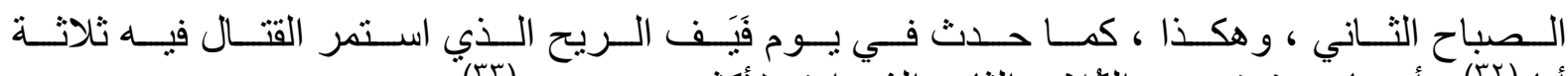

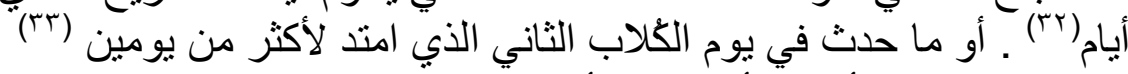

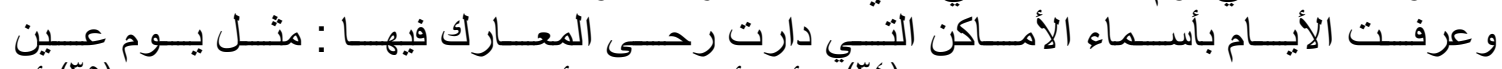

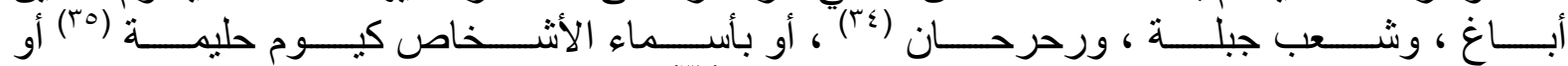

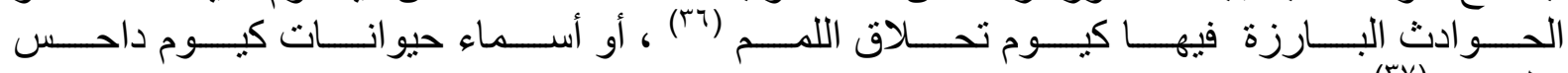
و الغبر اء (rv)

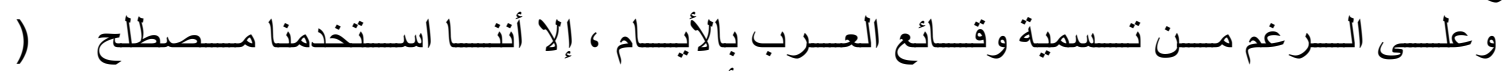

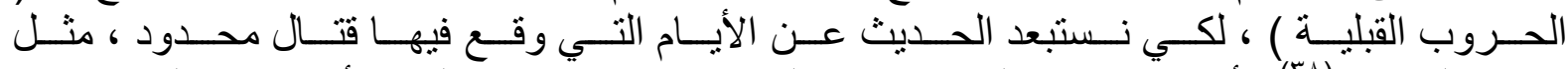

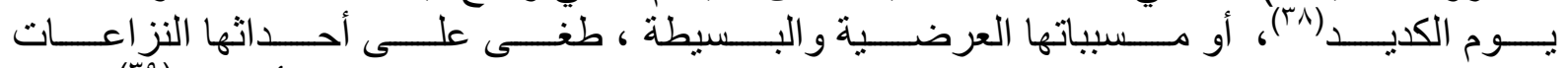

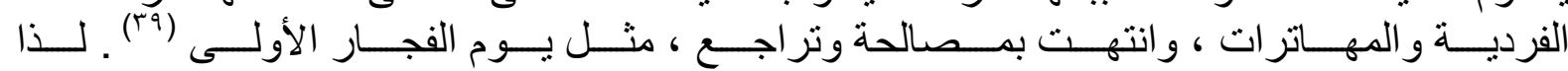

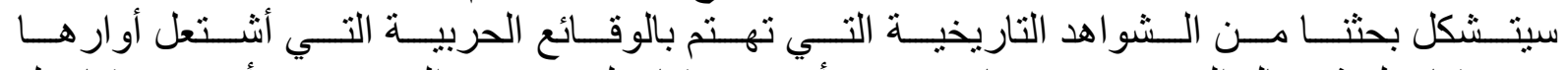

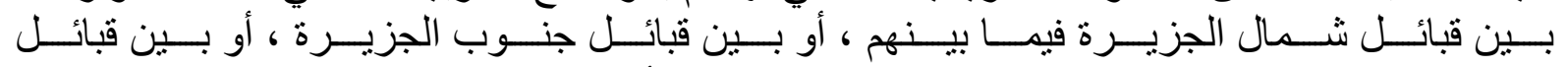

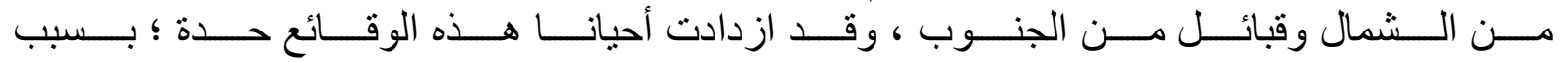

32 - أبو عبيدة ، نقائض جرير والفرزدق ، ج) ا، ص Vسr.

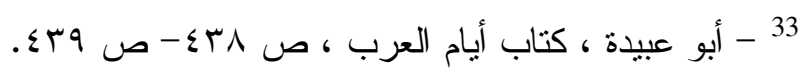
34 - عين أباغ : هو و اد ور اء الأنبار على طريق الفرات إلى الثام ،وكان عندها في الجاهلية يوم لهم بين ملوك غسان

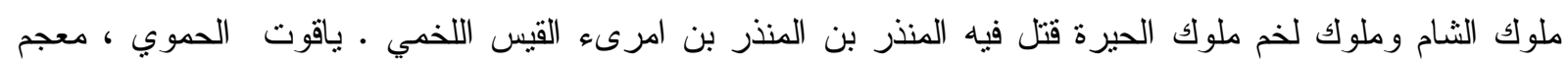

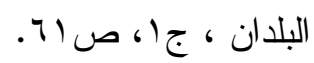
شعب جبلة الموضع الذي كانت فيه الوقعة المشهورة بين بني عامر وتميم وعبس وذبيان وفزارة ، وجبلة هذه هضبة

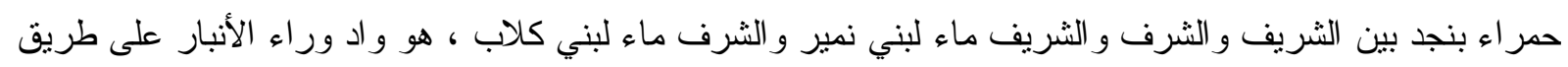

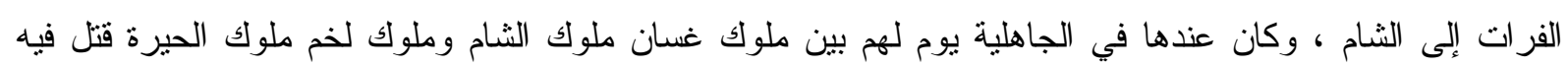

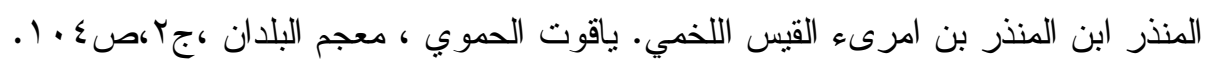

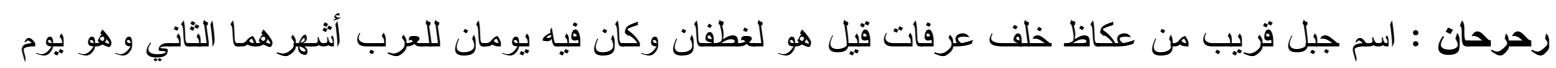

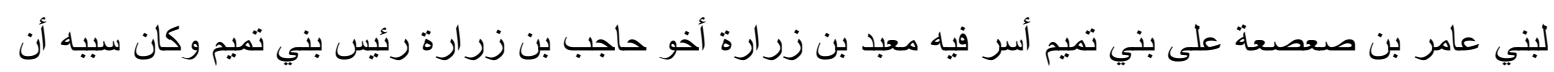

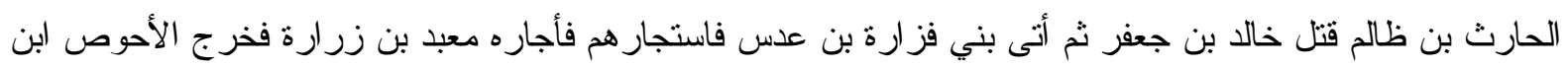

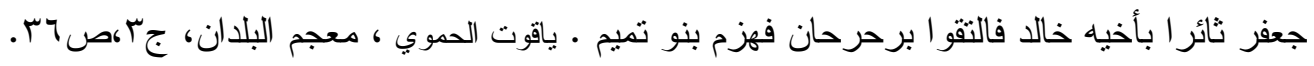

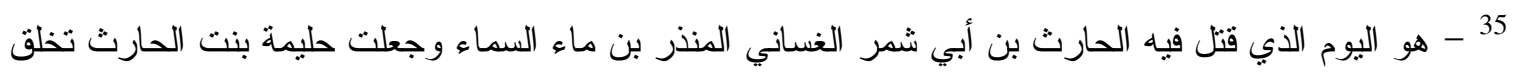

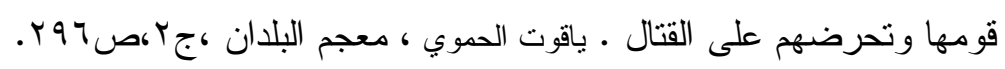

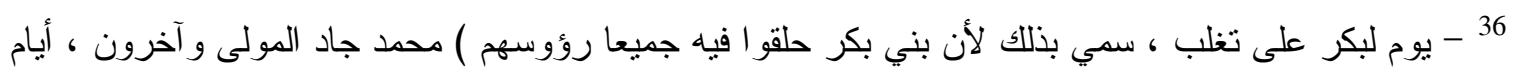

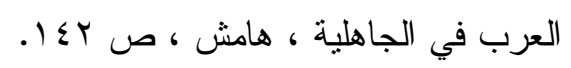

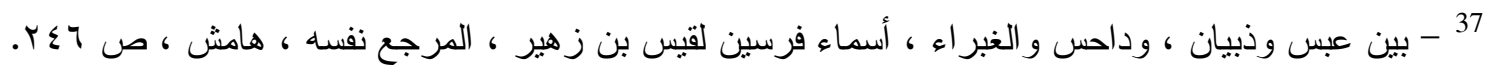

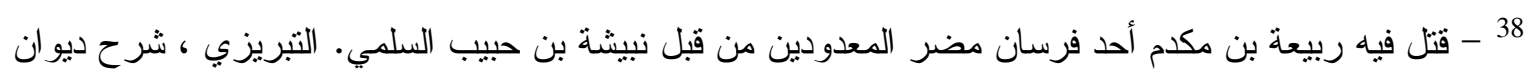

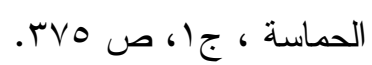
39 - حدث فيه قتال شخصي بين بدر بن معشر الغفاري ، و الأحمر بن مازن في سوق عكاظ ، وتحاور الحيان حتى الحى

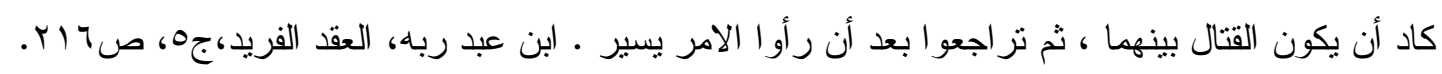




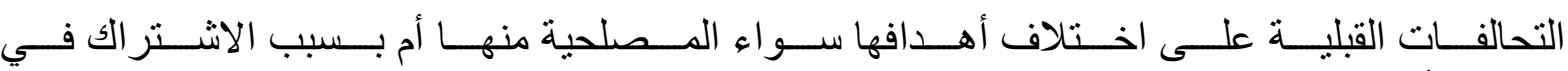
النسب الأعلى للقبائل .

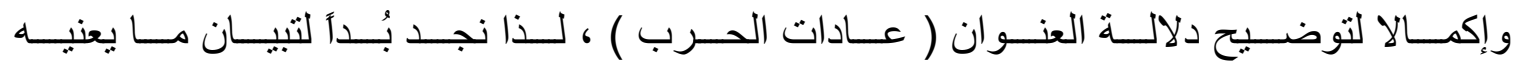

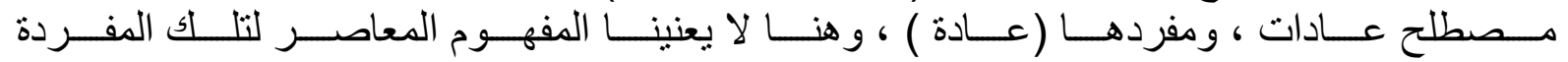

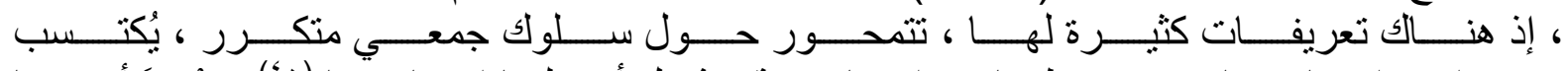

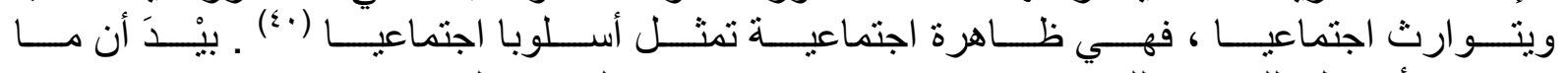

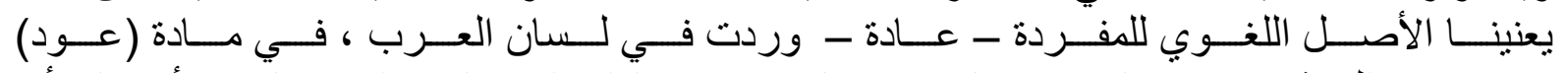

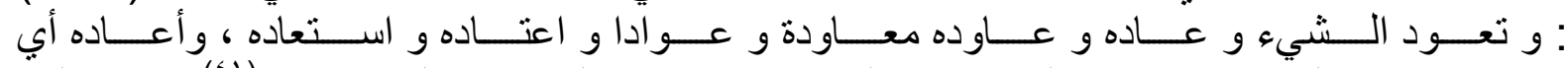

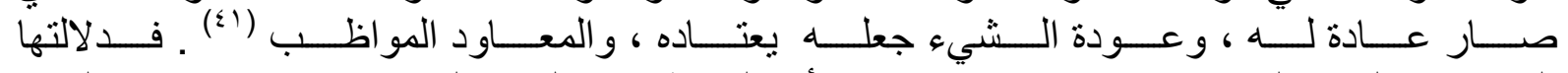

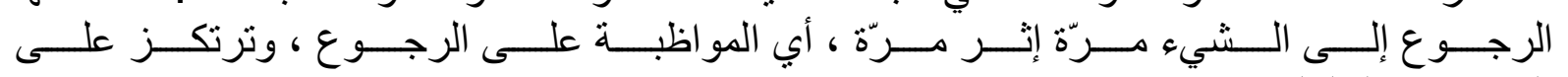
الشيوع في السلوك الاجتماعي . النيء

\section{عاداتهم في الحروب :}

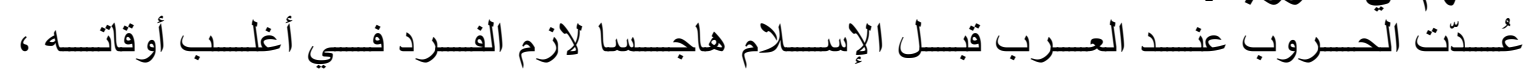

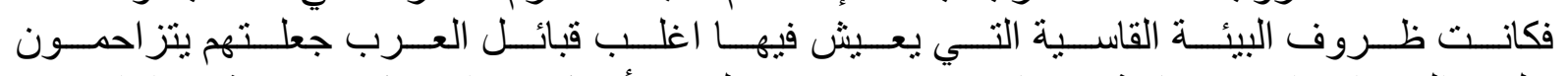

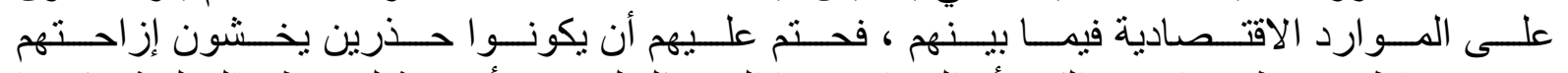

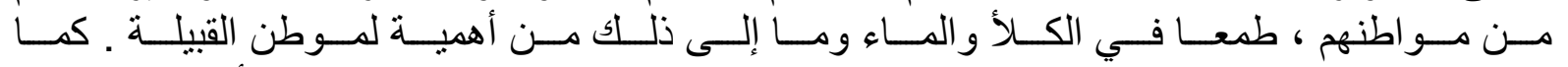

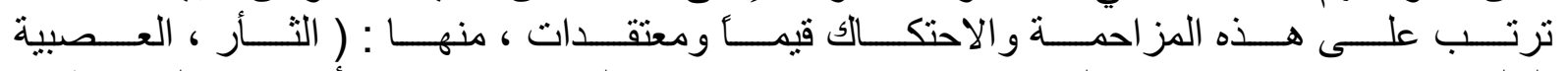

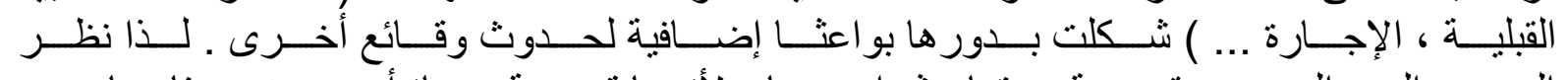

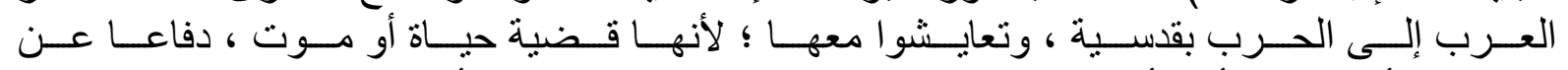

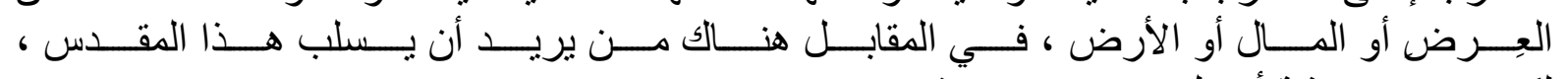

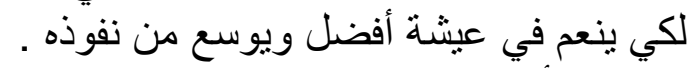

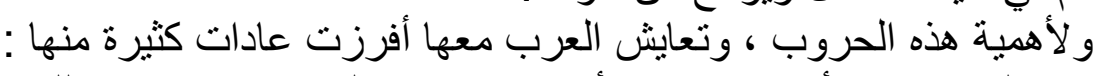

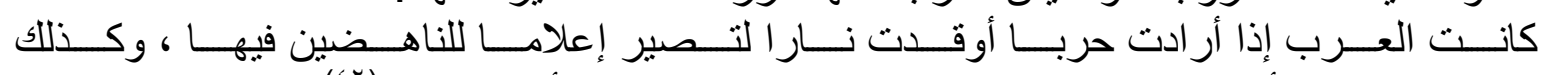

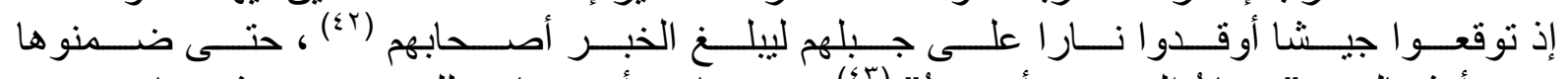

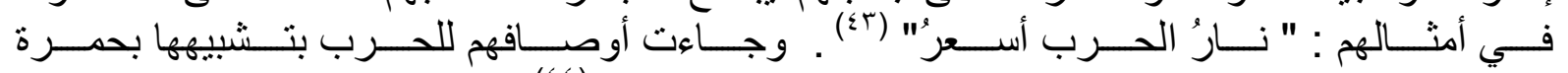

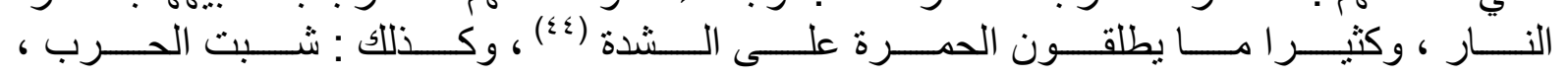

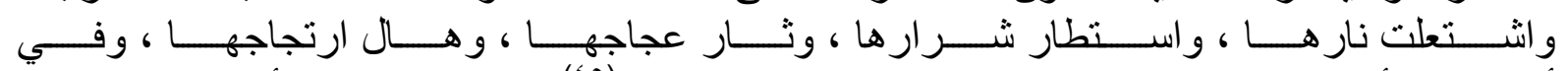

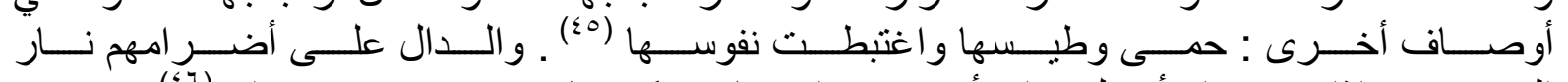

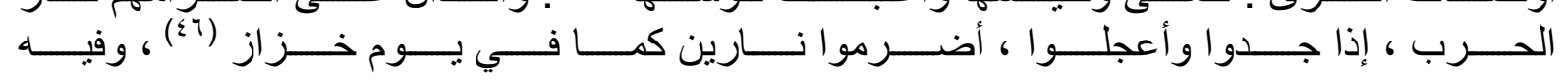

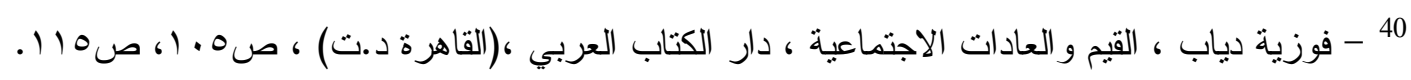
41

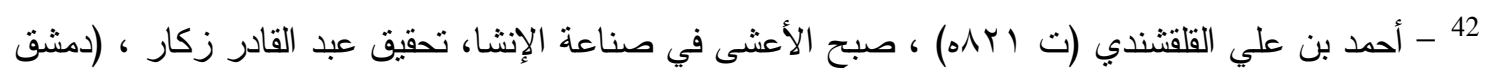

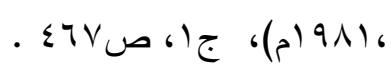
43 44

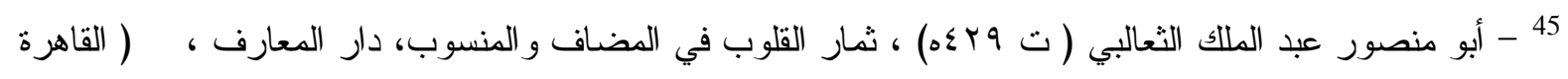

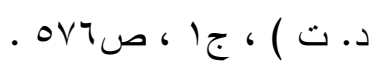
46 - بال ثناثة بطخفة ما بين البصرة إلى مكة فمتالع عن يمين الطريق للذاهب إلى مكة وكير عن شماله 


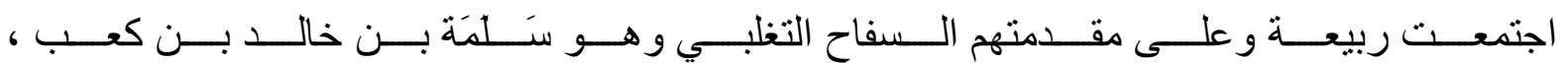

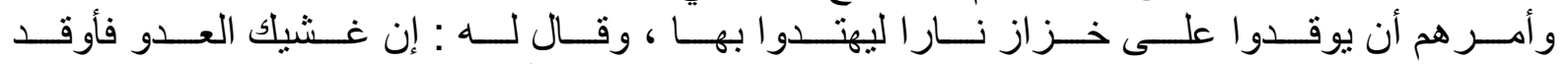

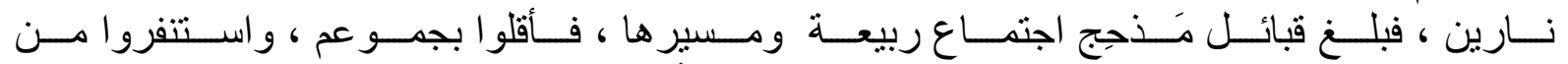

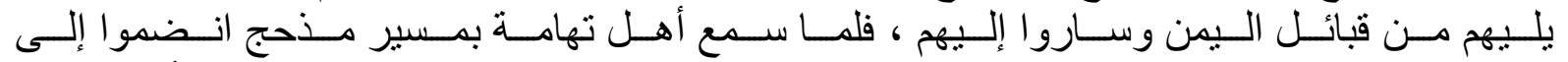

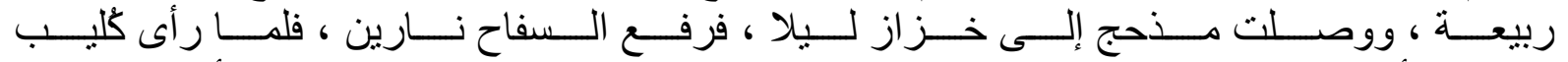

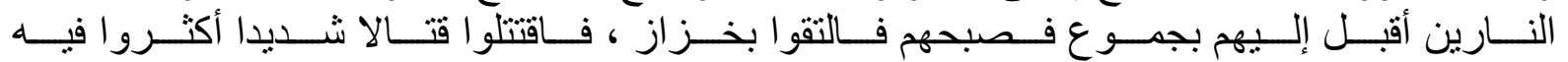

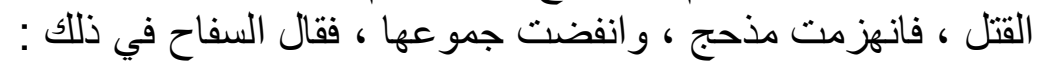

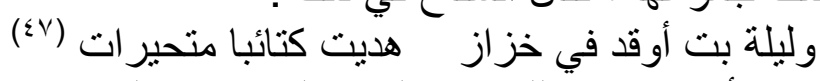

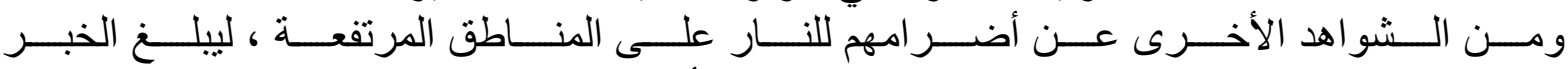

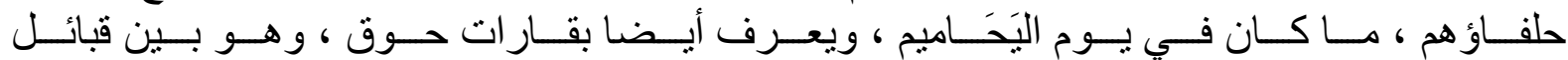

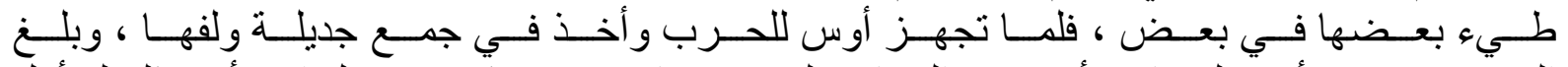

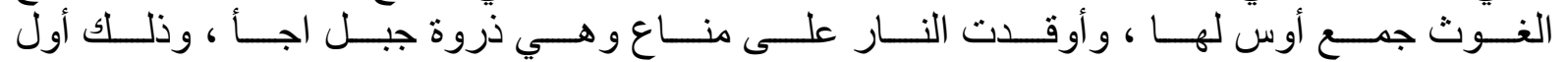

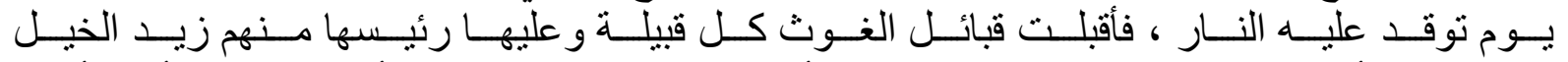

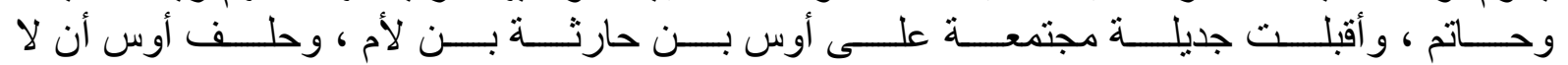

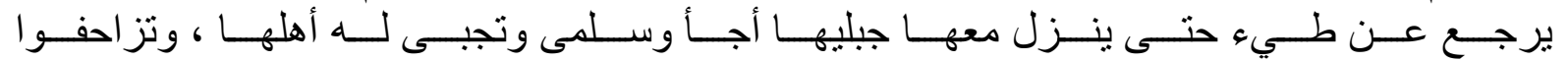

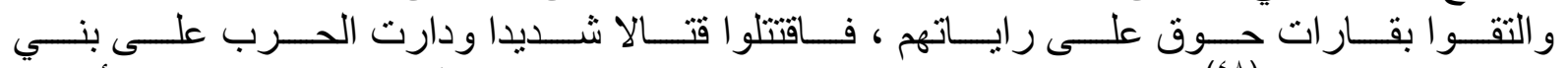

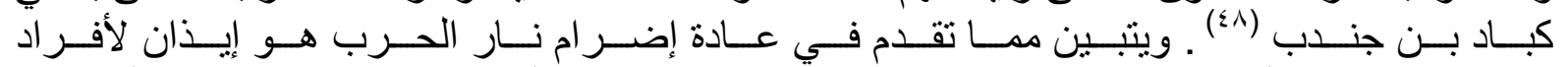

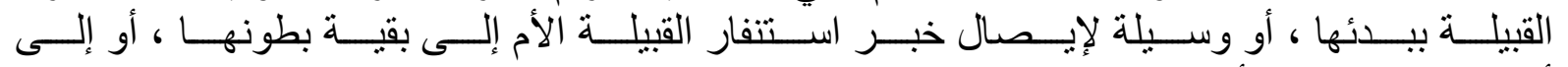

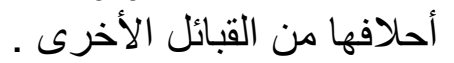

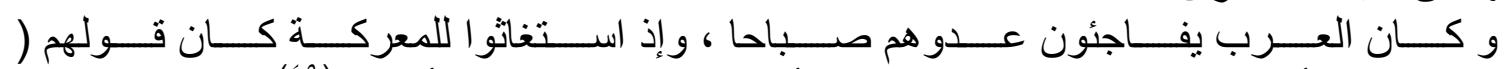

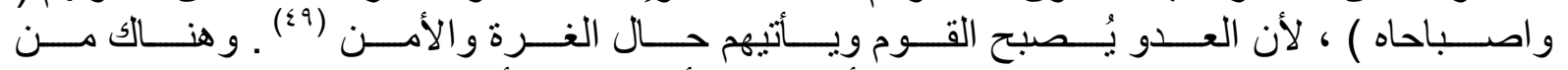

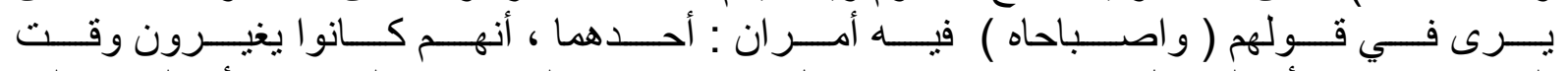

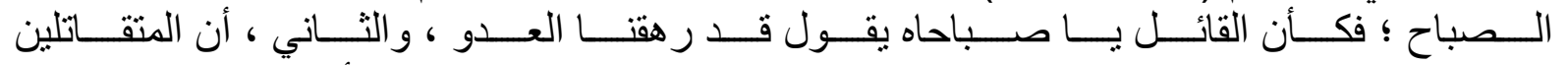

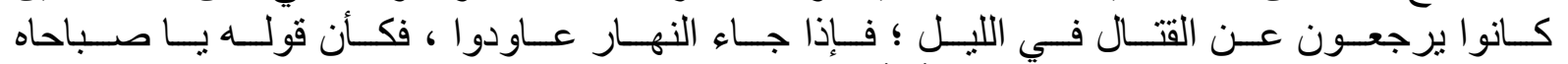

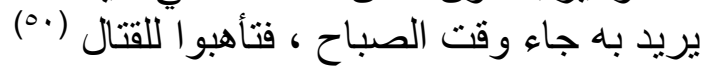

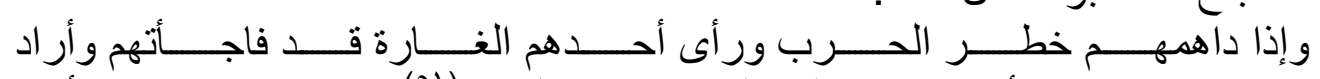

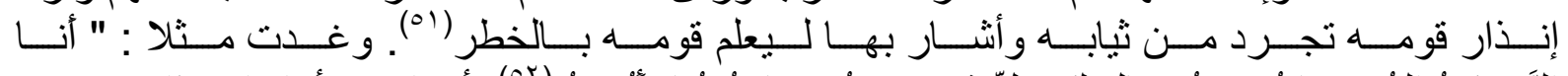

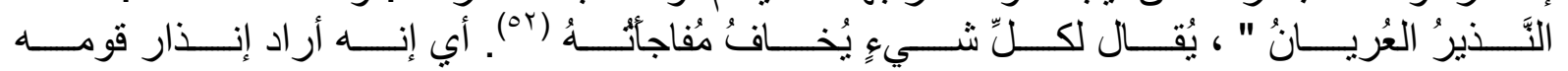

وخز از بنحر الطريق إلا أنها لا يمر الناس عليها ثلاثتها وقيل خزاز جبل لبني غاضرة خاصة ، ياقوت

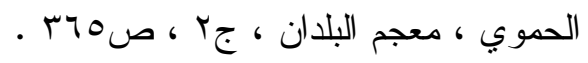

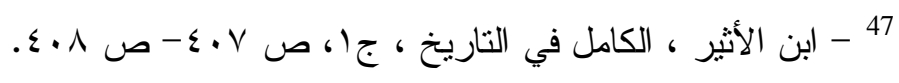

$$
\begin{aligned}
& 48
\end{aligned}
$$

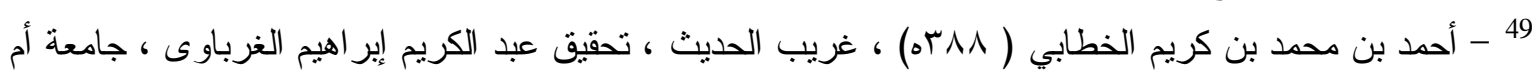

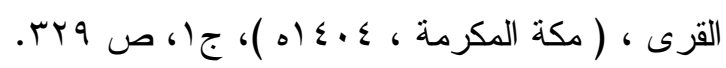

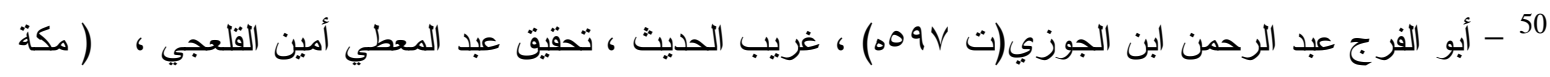

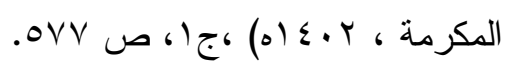

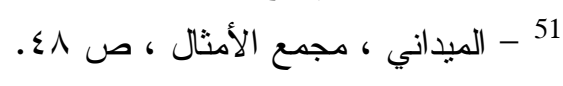

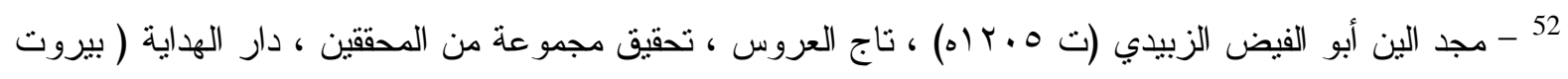

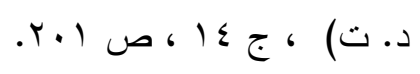




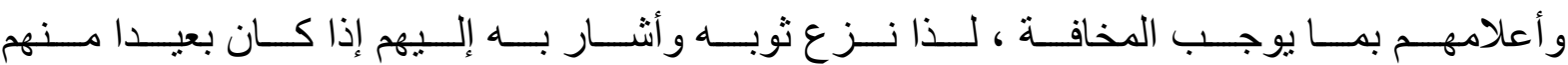

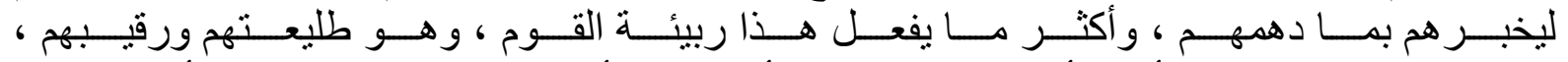

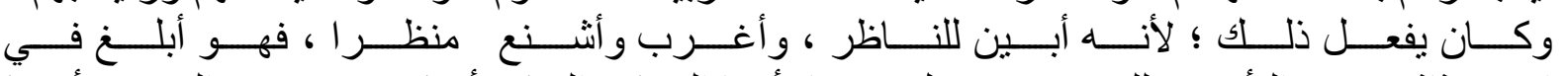

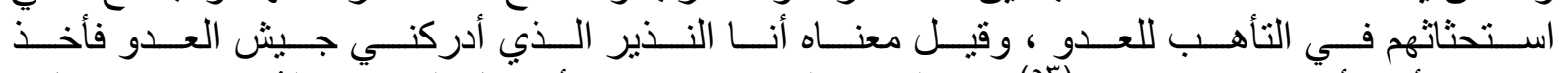

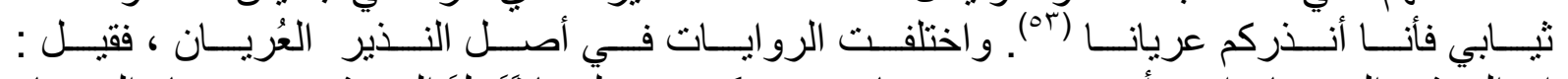

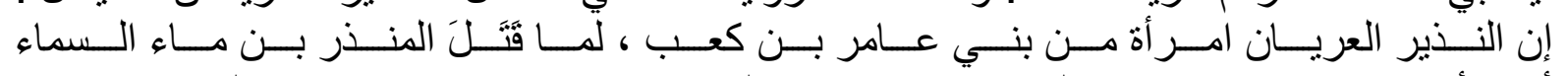

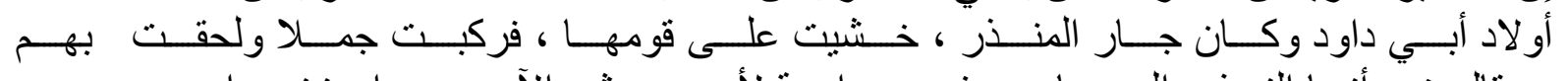

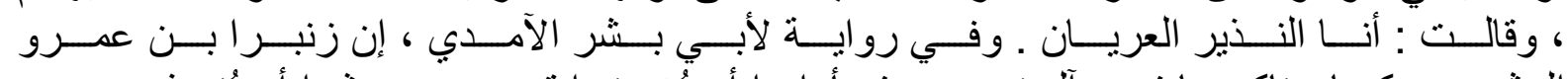

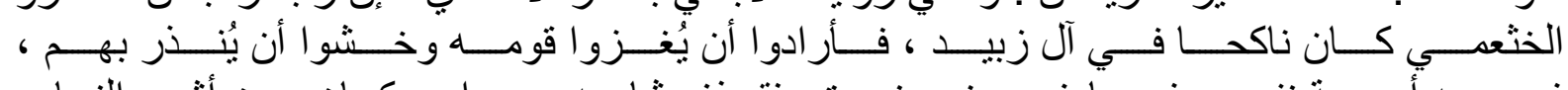

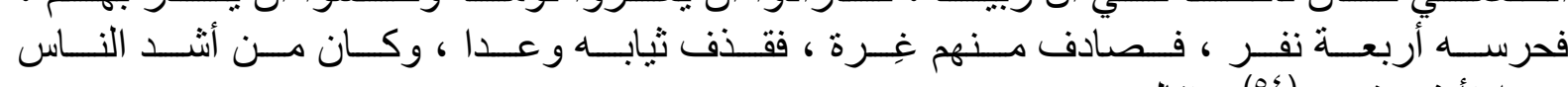

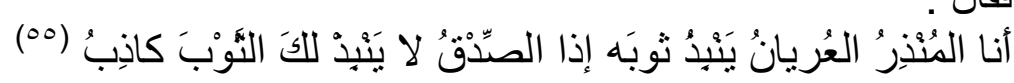

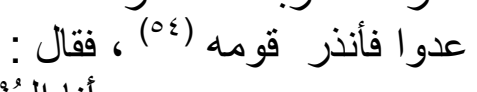

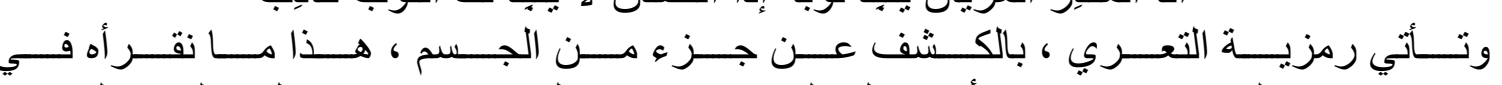

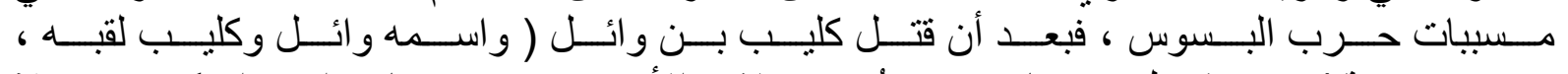

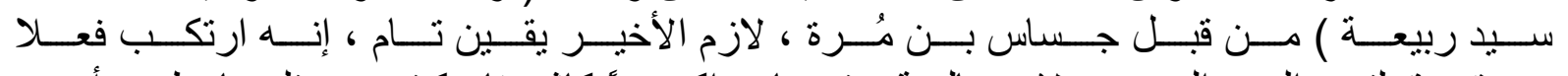

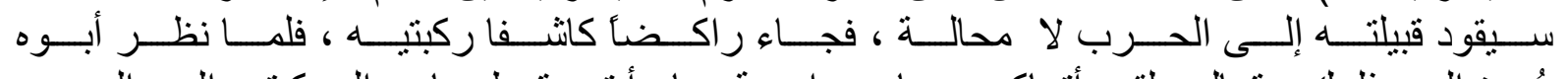

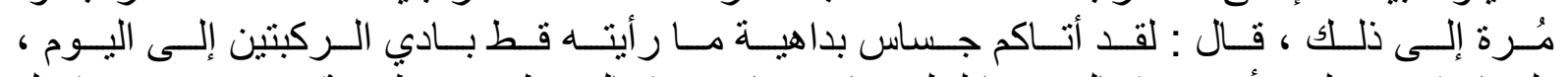

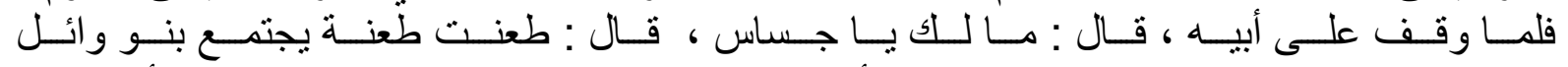

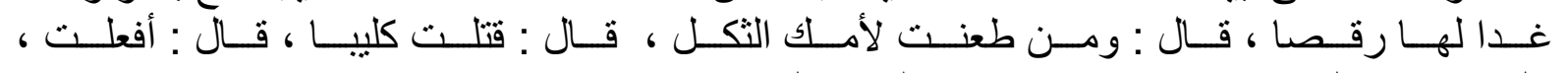

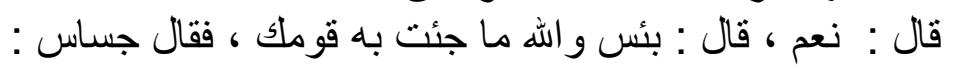

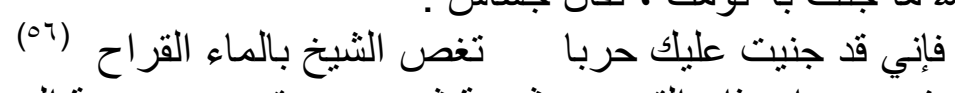

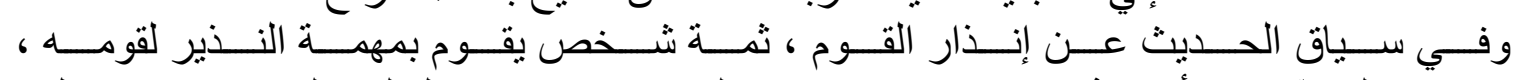

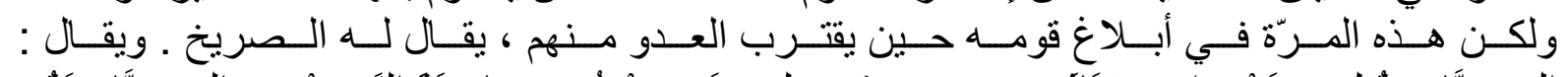

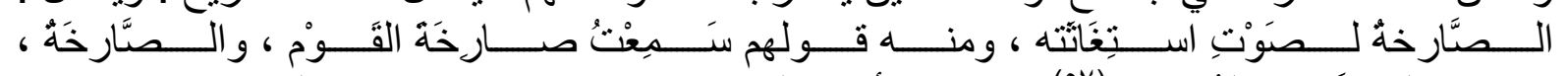

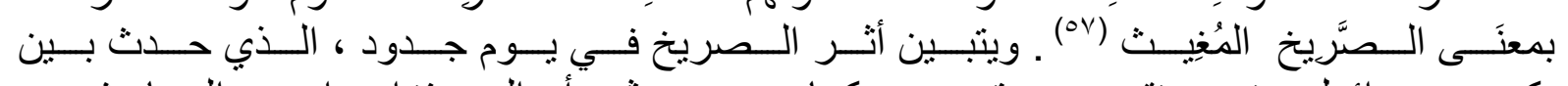

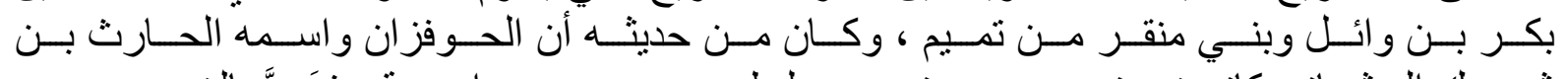

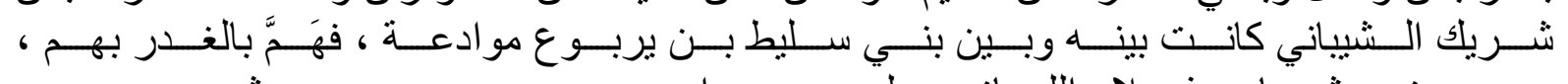

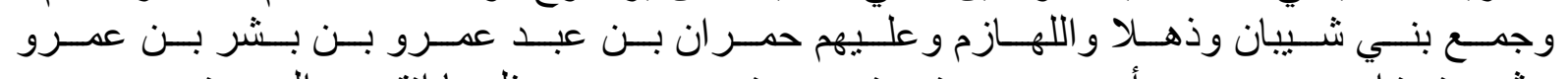

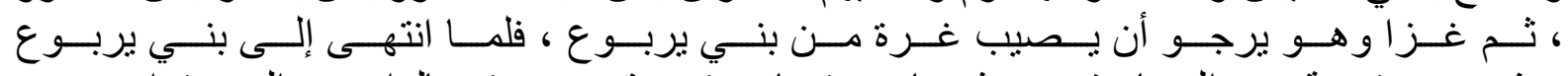

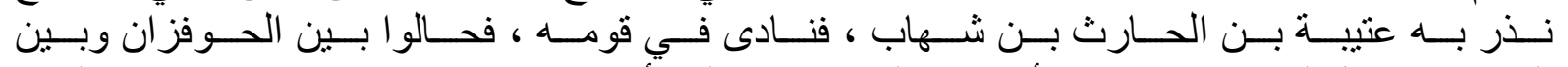

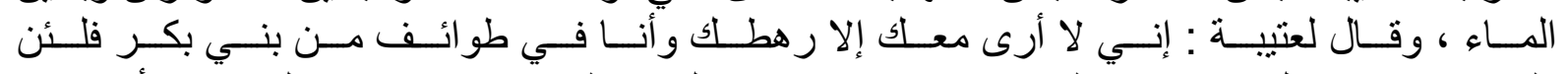

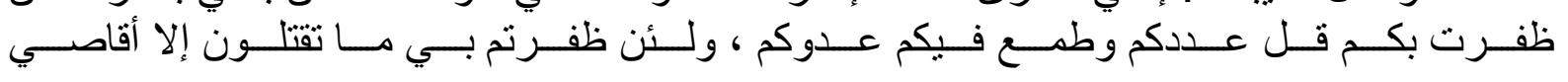

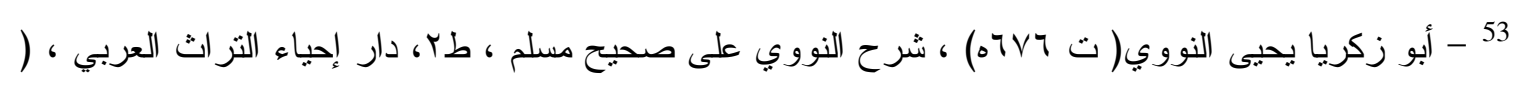

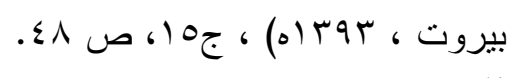

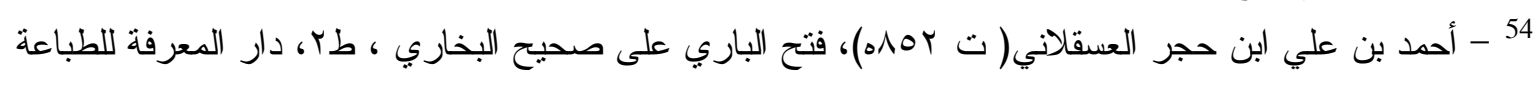

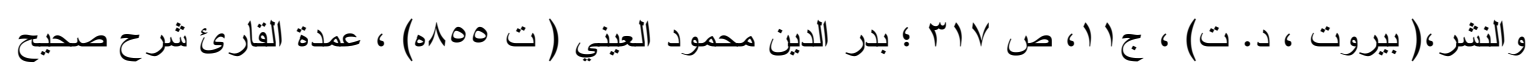

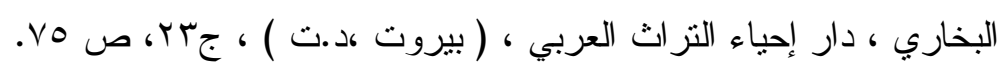
55

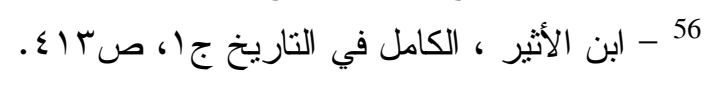

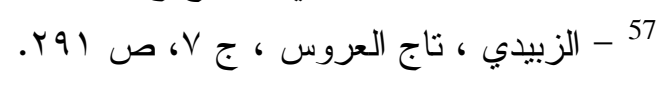




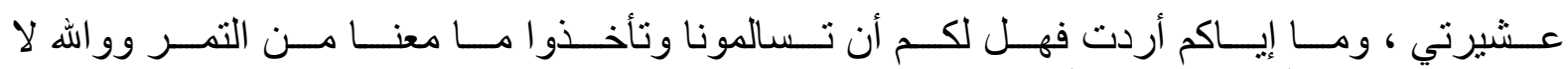

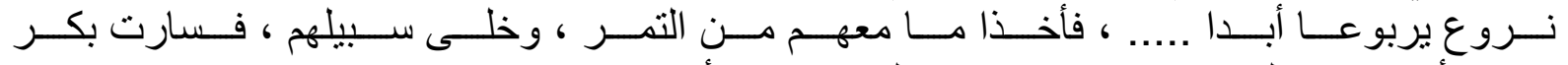

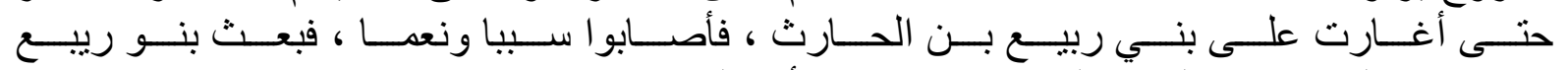

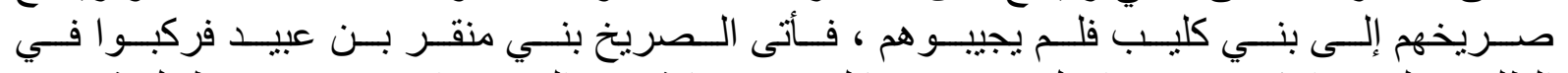

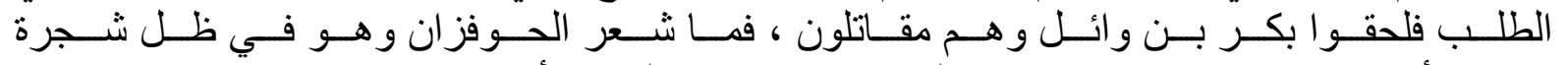

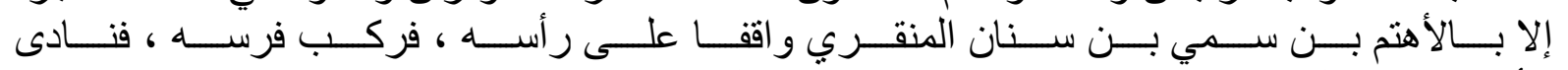

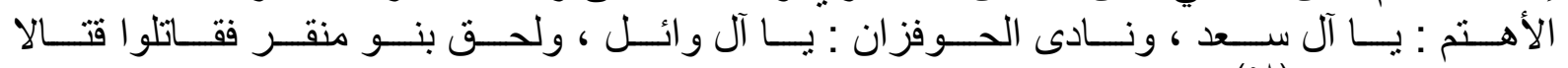

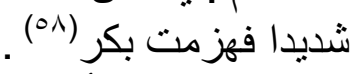

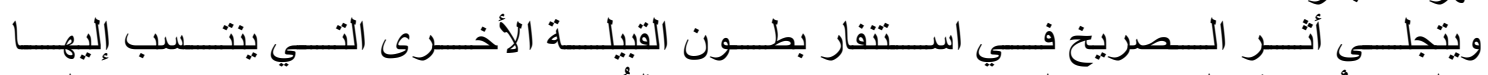

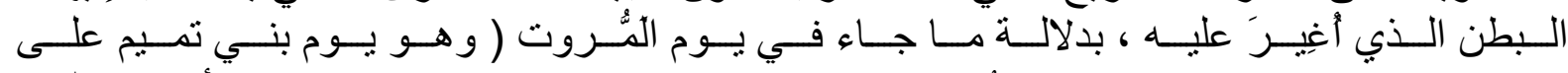

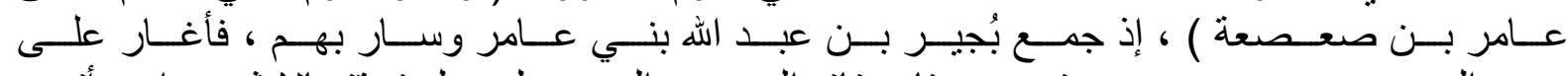

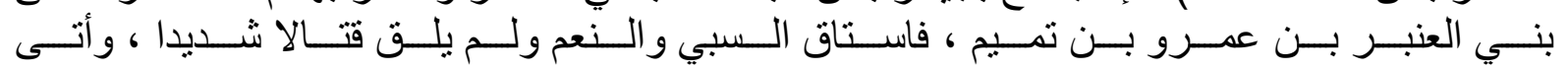

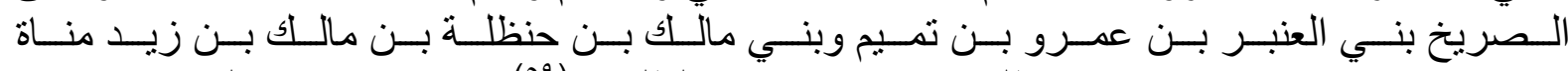

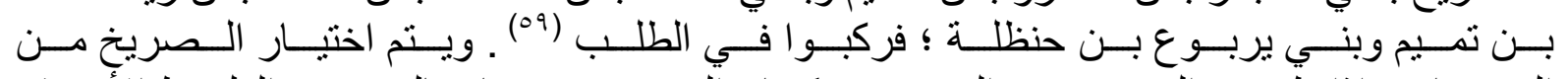

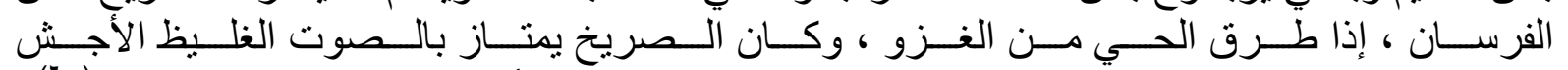

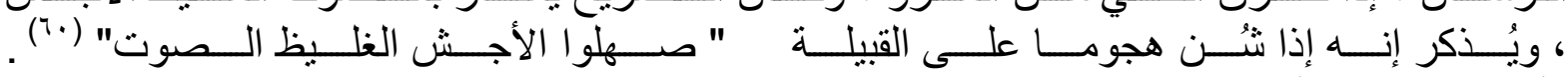

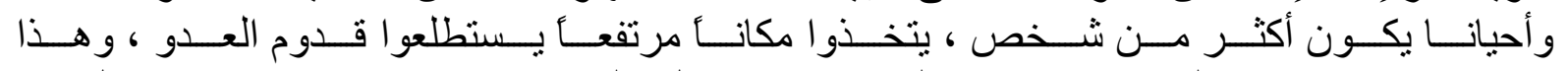

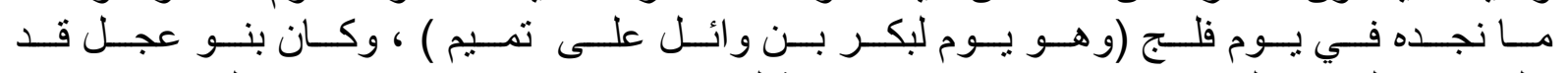

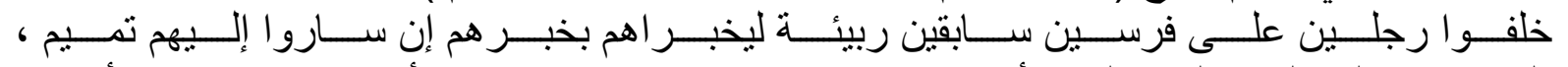

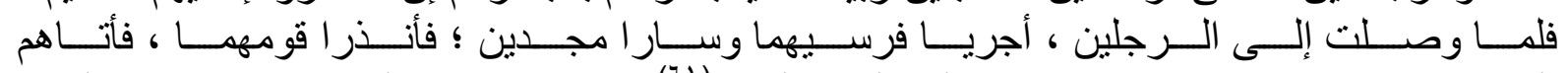

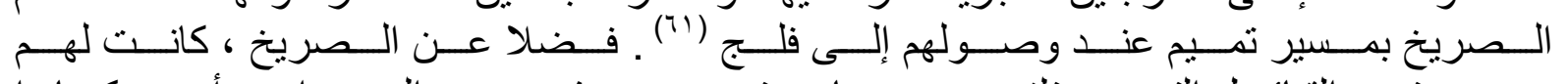

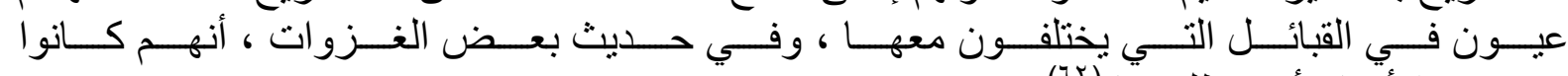
يتحسبون الأخبار أي ينطلبونها (ri)

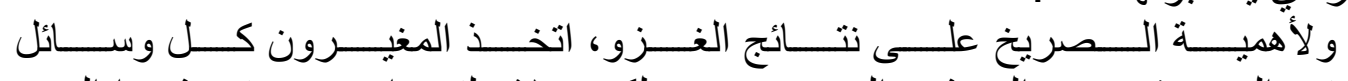

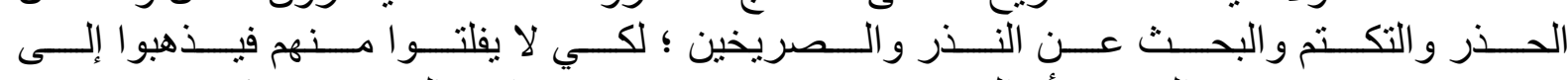

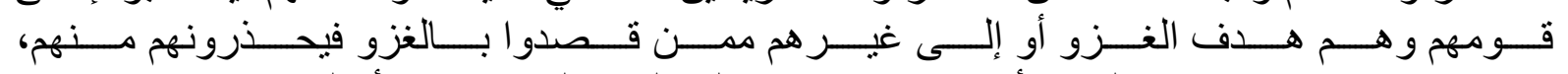

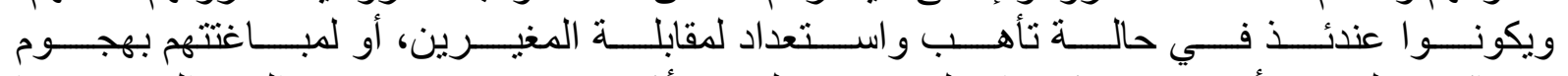

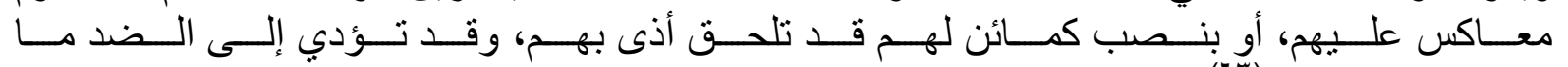
قصد من ذلك الغزو (r)

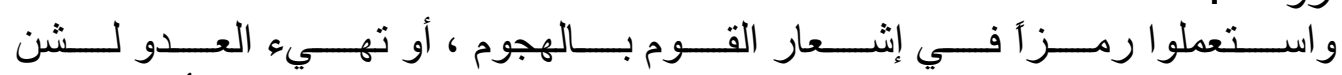

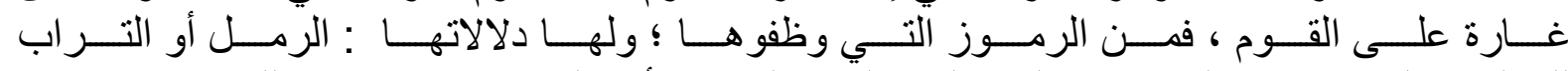

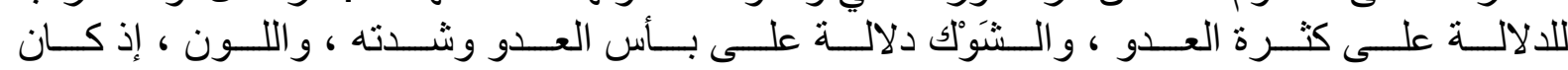

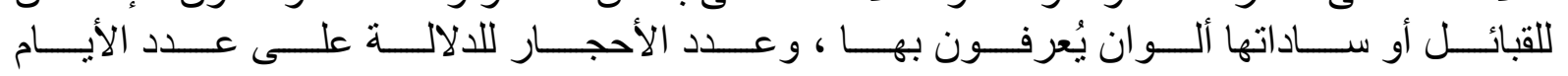

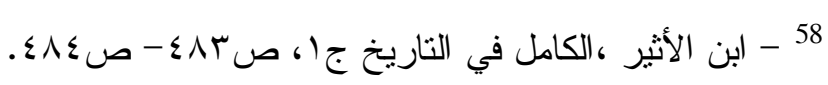

$$
\begin{aligned}
& 59 \\
& 60 \\
& 61
\end{aligned}
$$

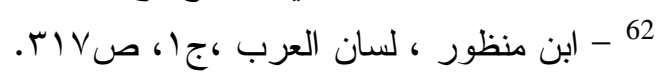

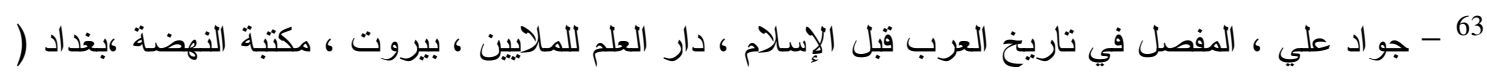




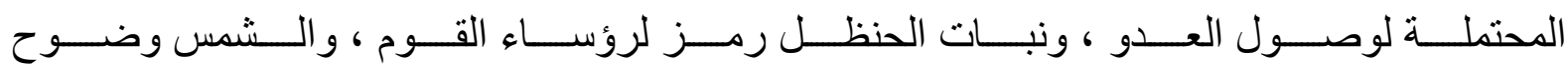

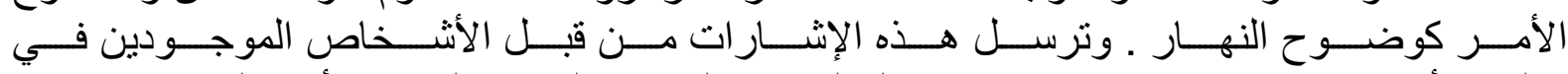

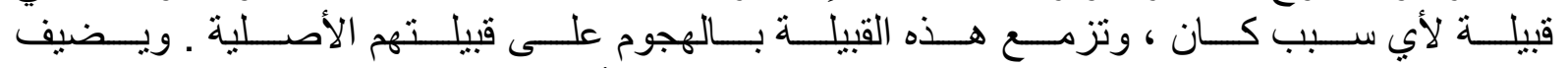

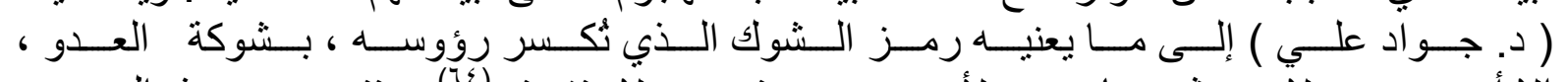

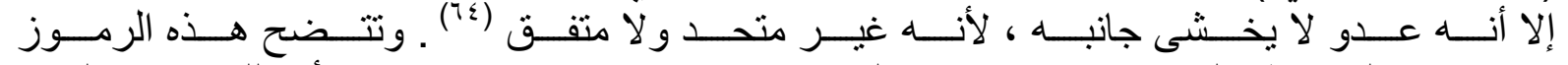

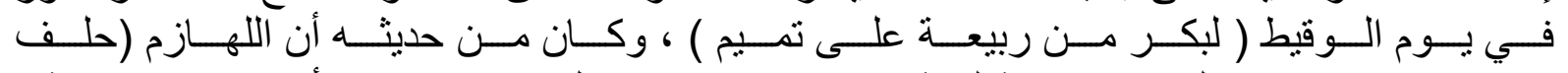

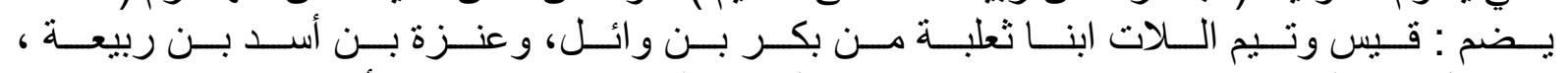

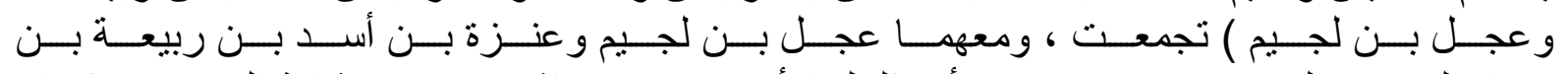

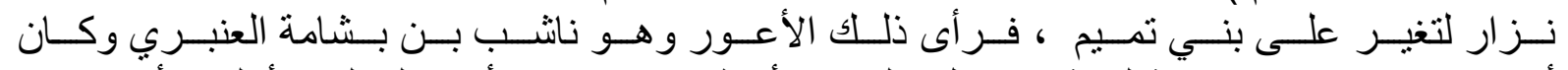

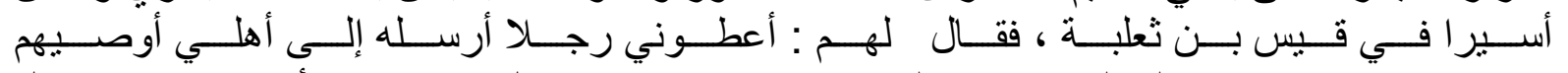

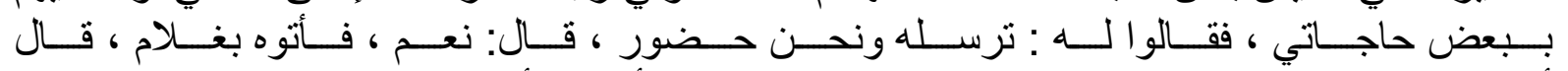

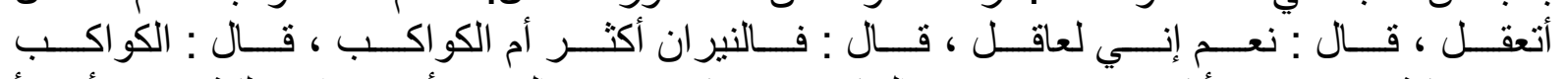

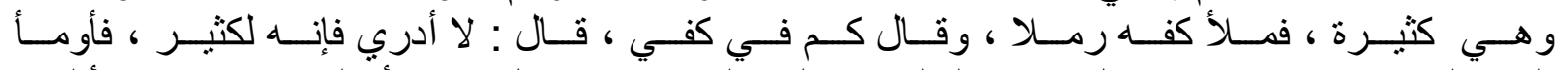

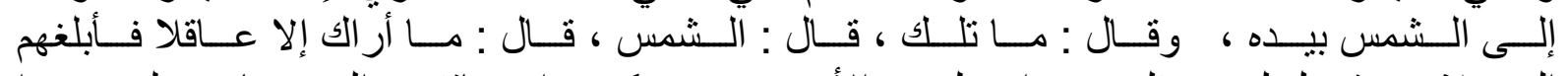

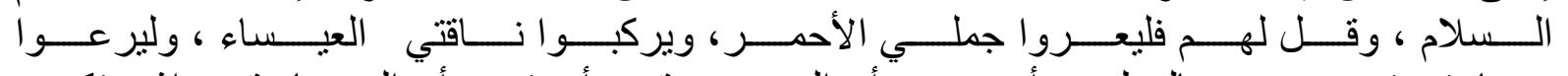

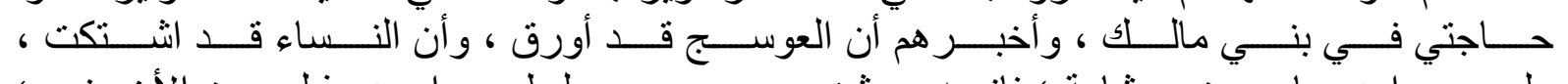

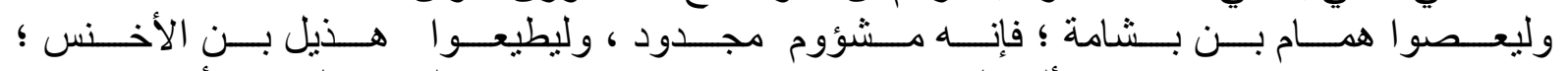

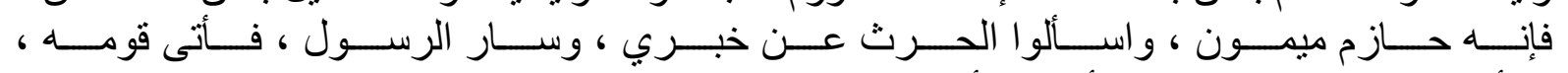

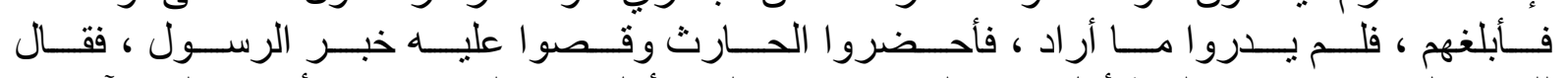

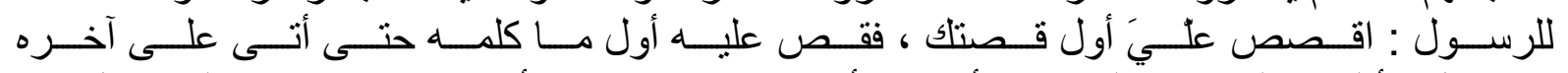

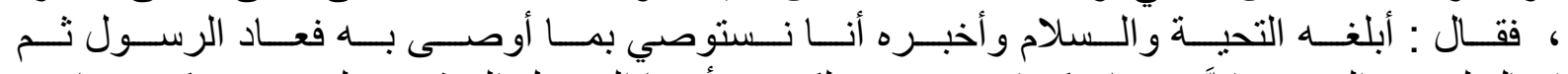

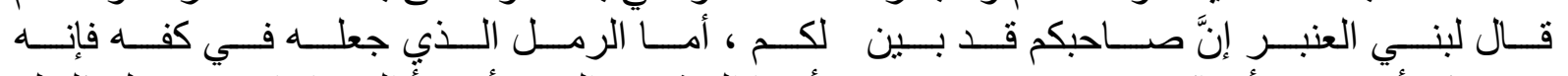

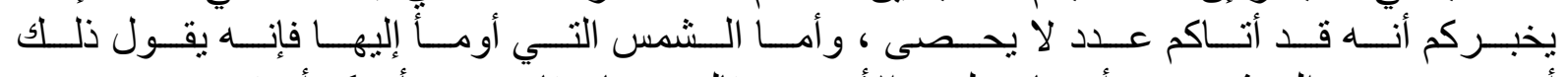

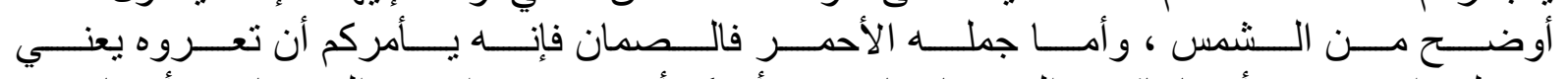

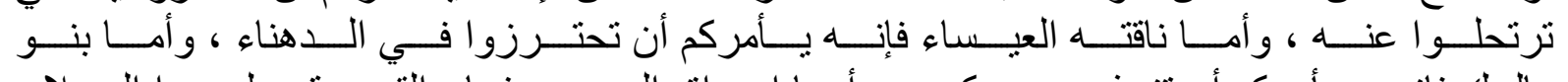

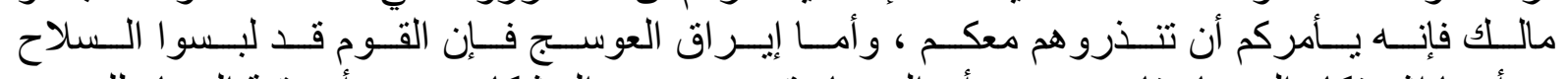

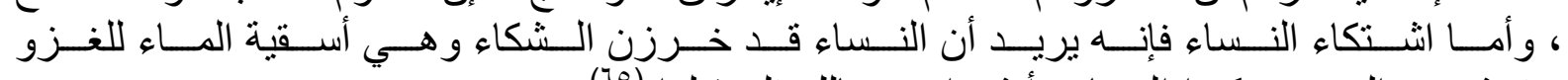

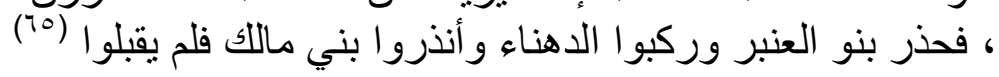

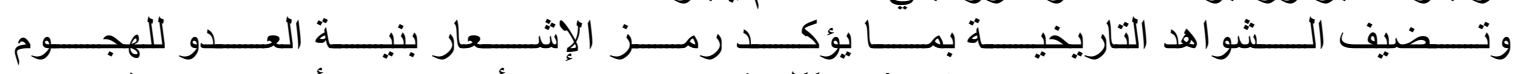

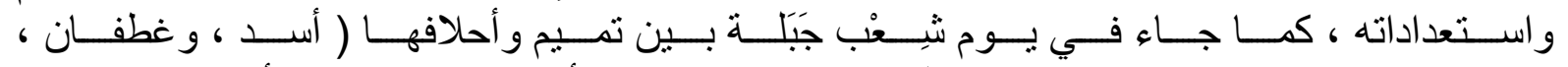

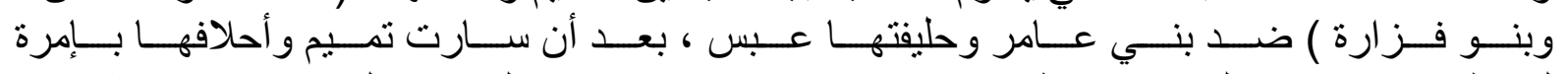

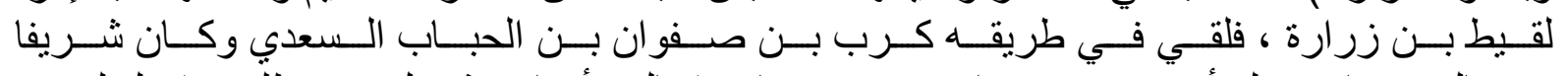

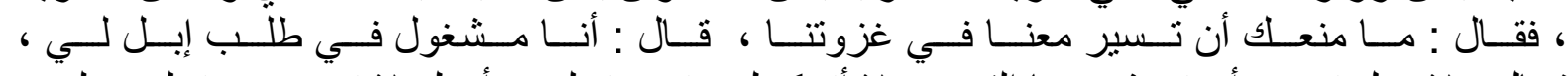

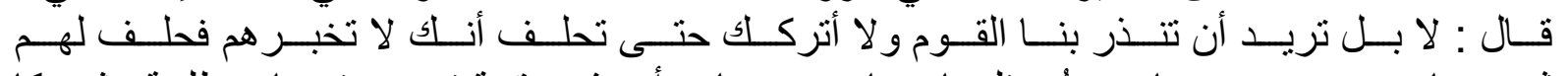

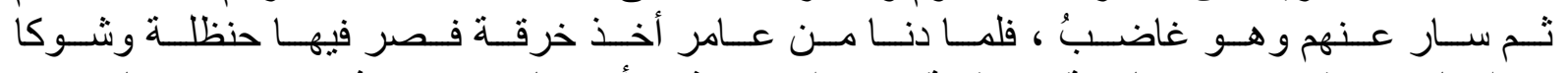

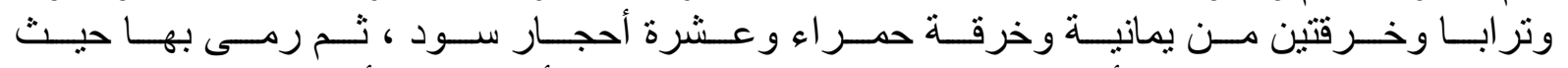

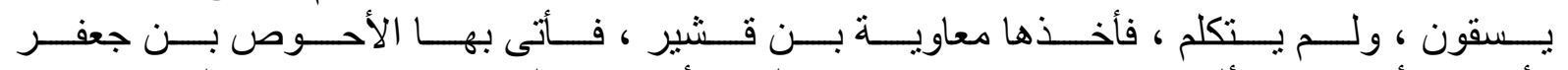

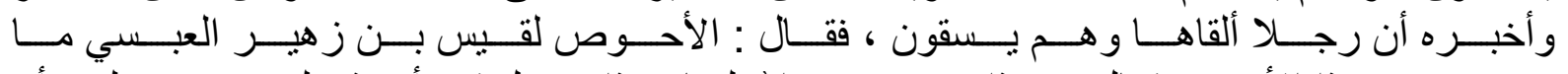

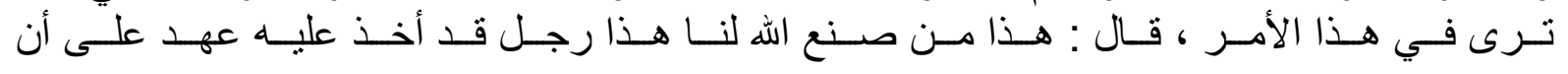

$$
64
$$

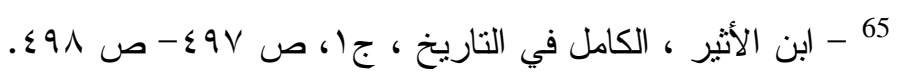




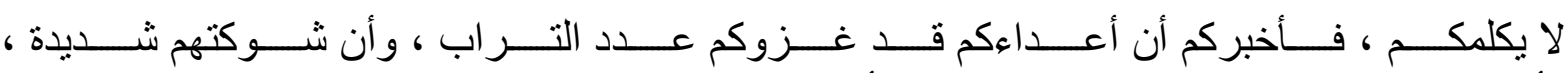

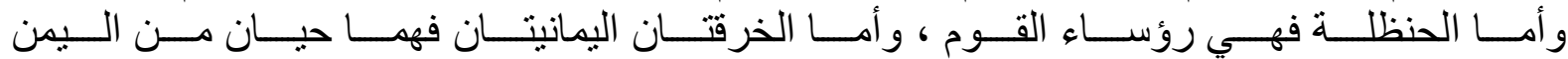

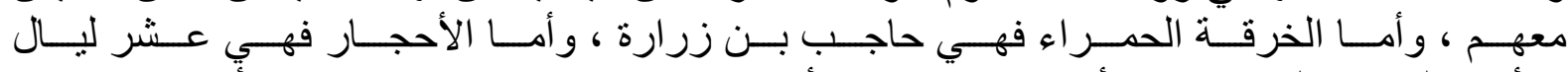

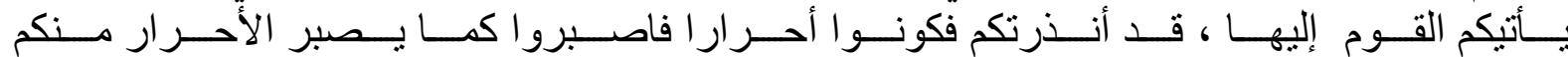

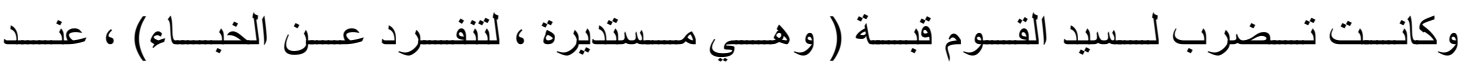

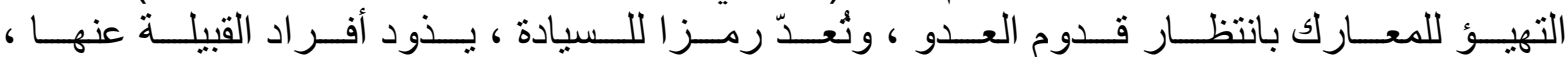

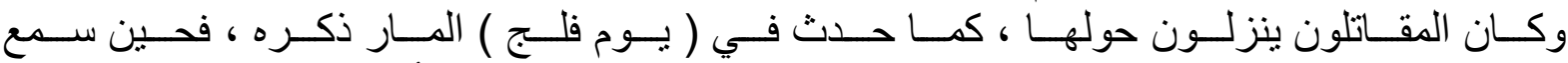

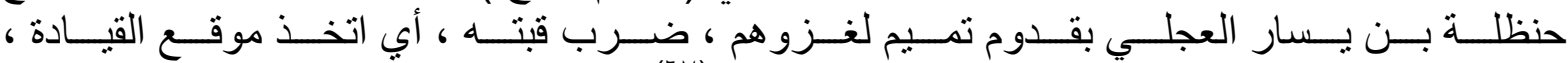

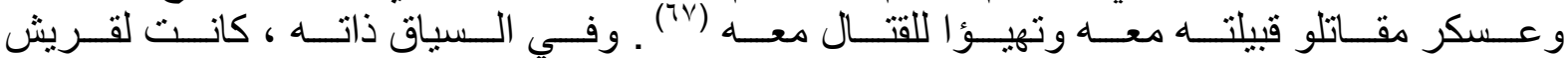

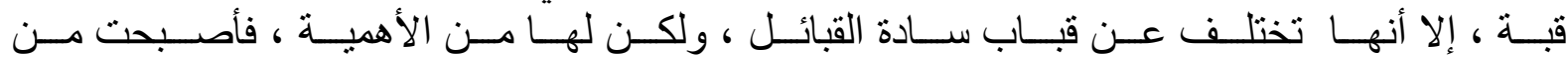

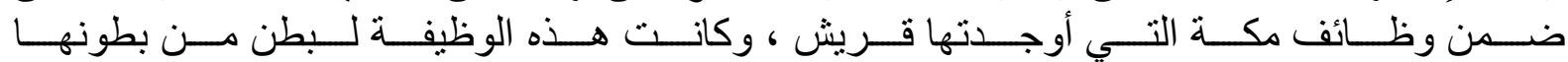

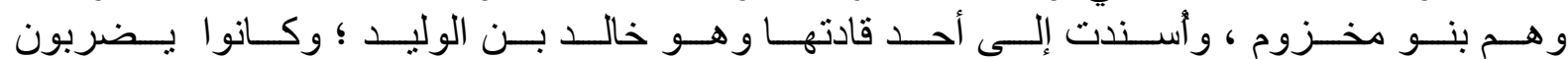

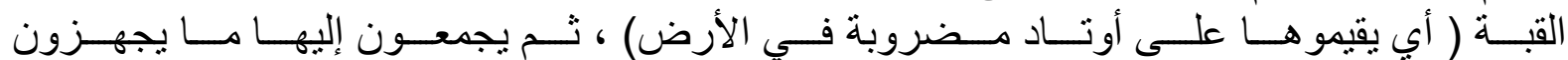

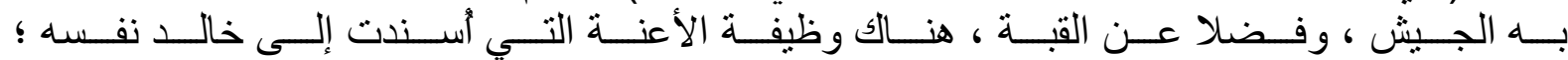

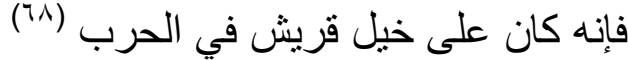

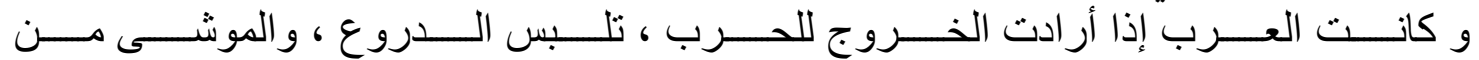

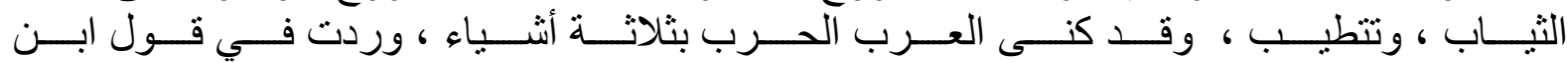

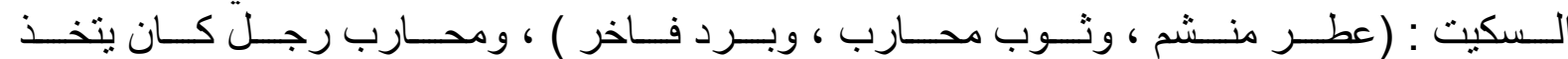

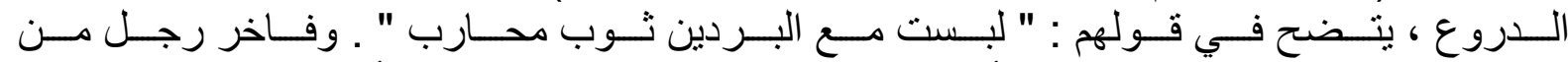

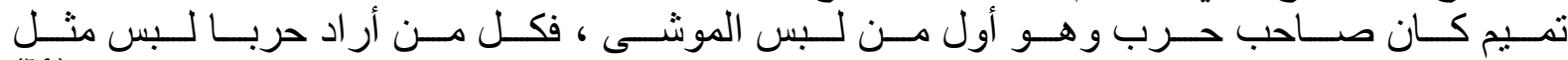

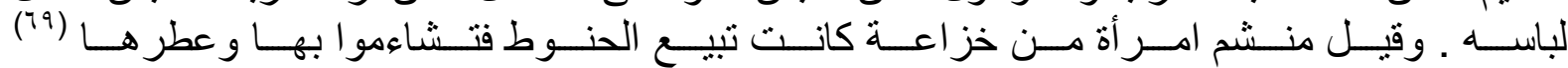

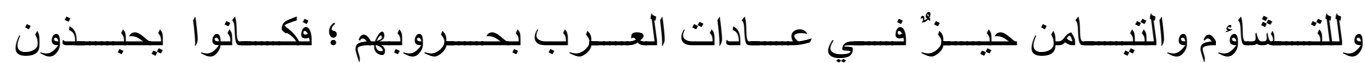

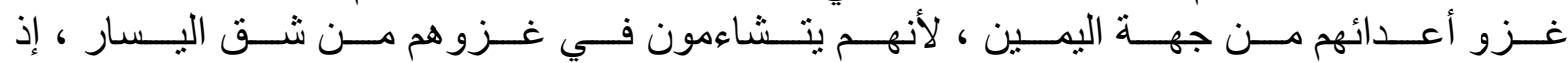

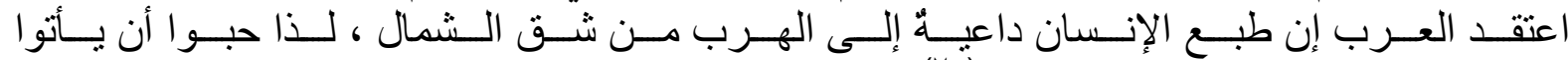

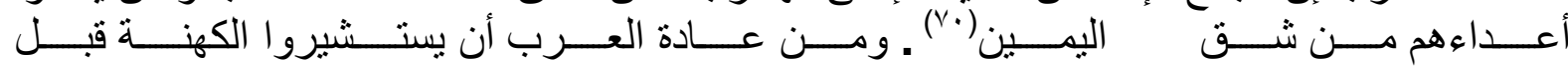

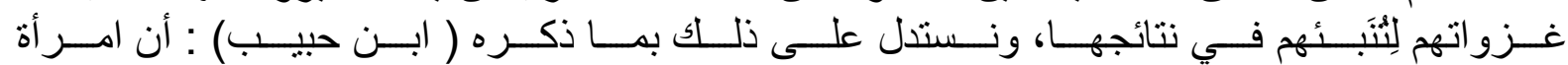

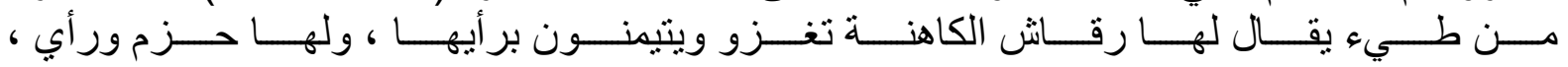

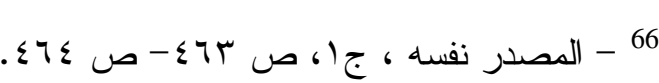

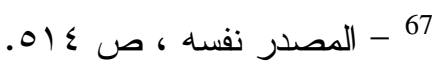

$$
\begin{aligned}
& 68
\end{aligned}
$$

69 - الحسن بن سهل أبو هلال العسكري (ت القرن الخه الخامس الهجري ) ، جمهرة الأمثال ، دار الفكر ، ( بيروت ،

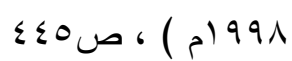

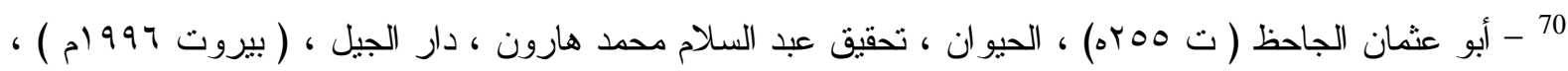
جr ، ص ع إ. 


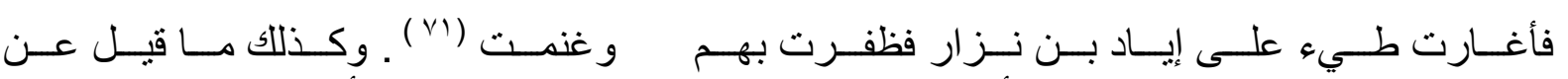

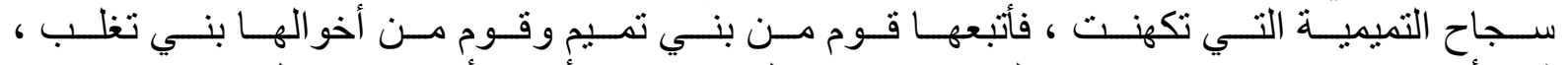

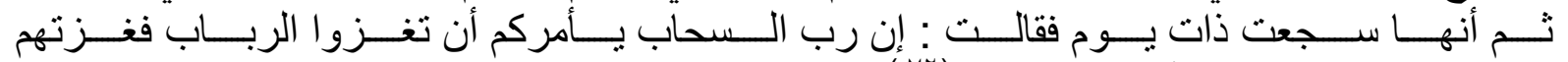

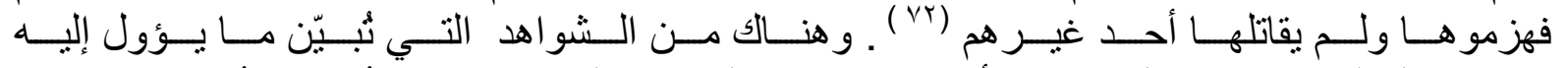

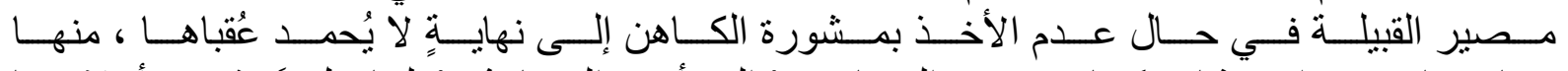

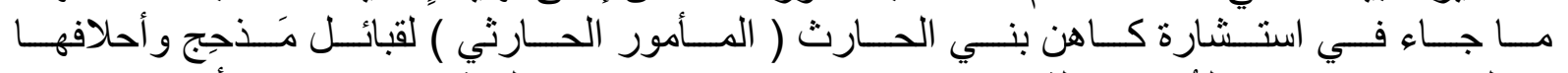

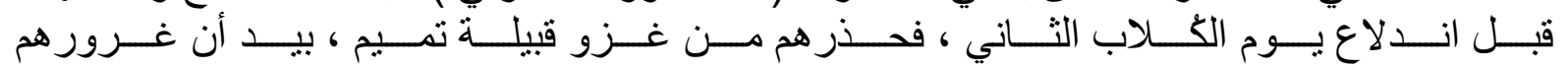

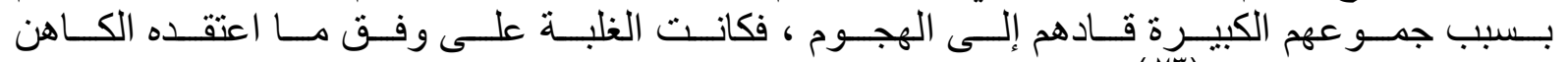

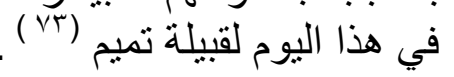

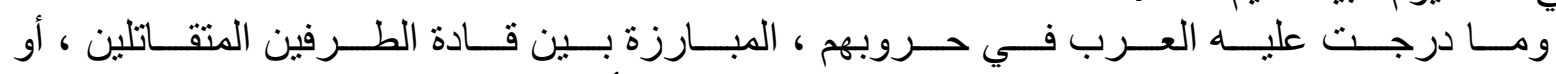

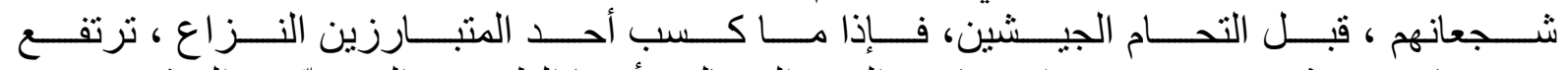

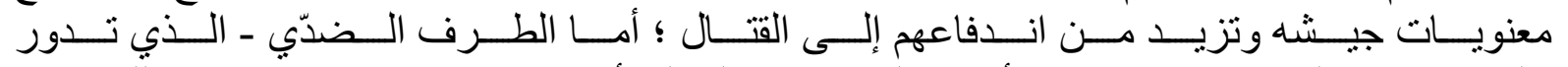

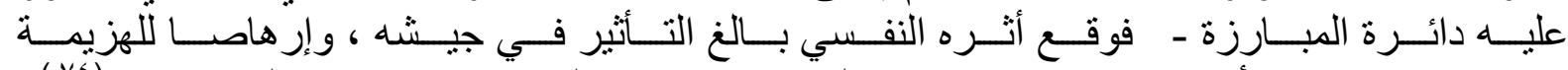

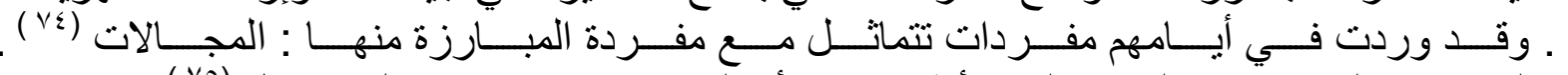

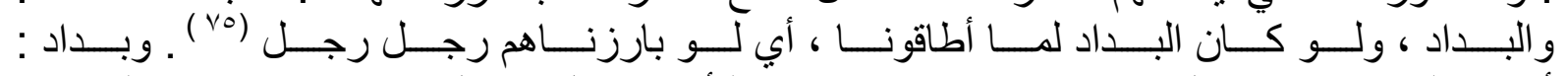

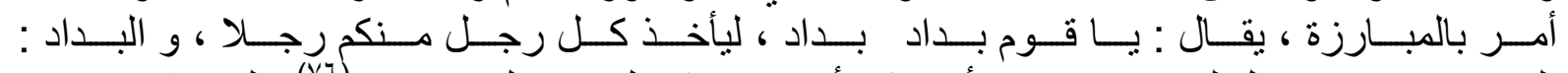

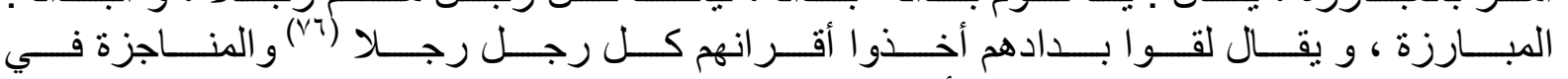

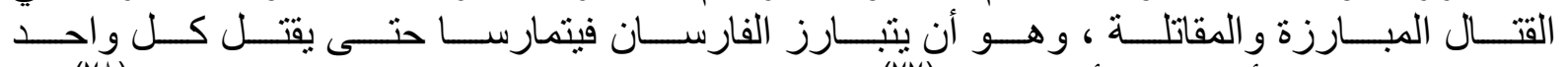

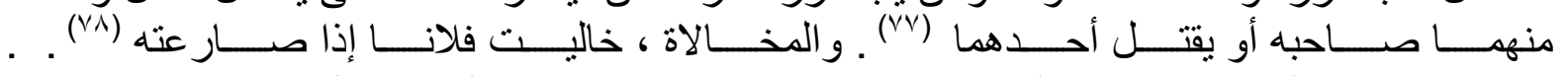

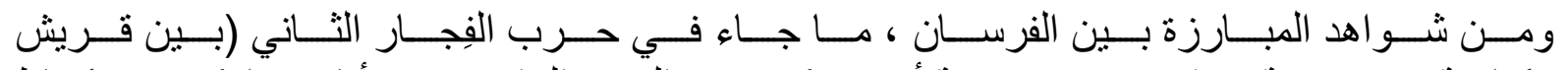

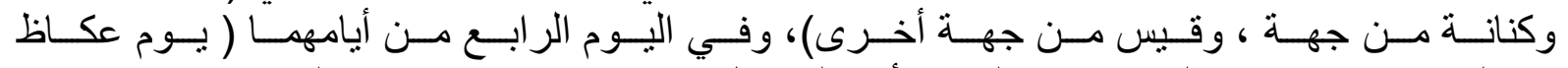

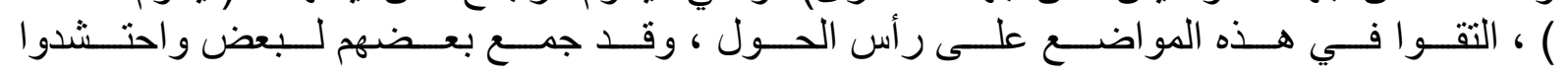

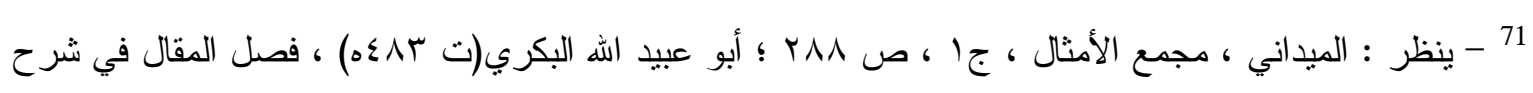

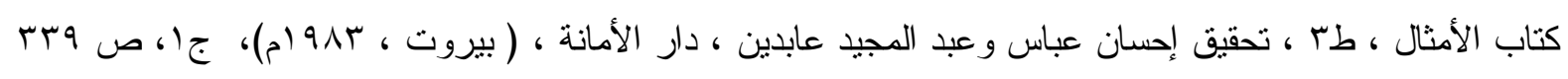

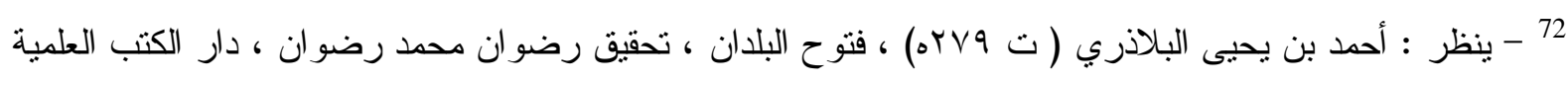

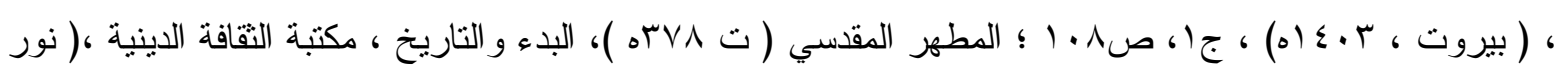

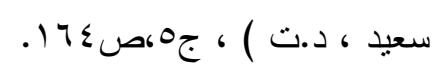

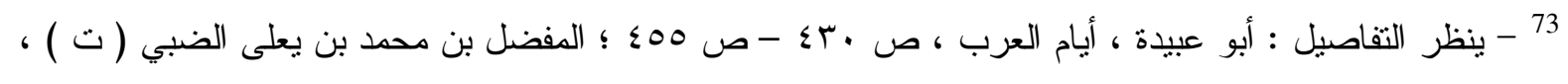

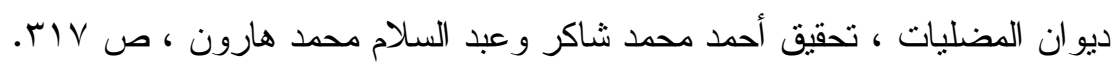

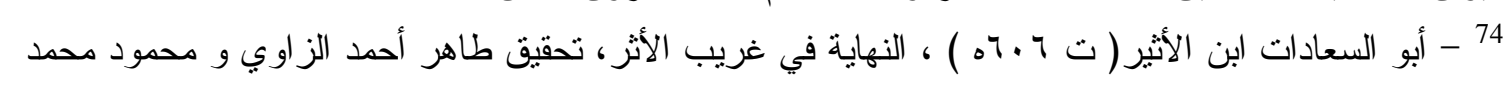

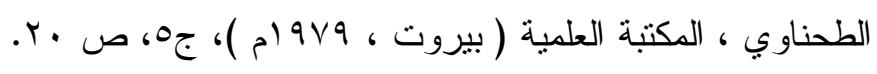

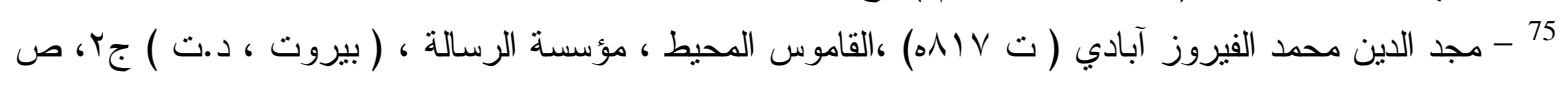

$. r \varepsilon)$

76 - إبر اهيم مصطفى و آخرون ، المعجم الوسيط ، دار الدعوة ، د.ت ) تحقيق مجمع اللغة العربية ،( د. ت ) ، ج)،

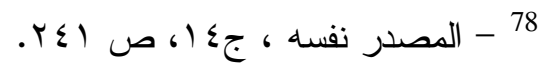




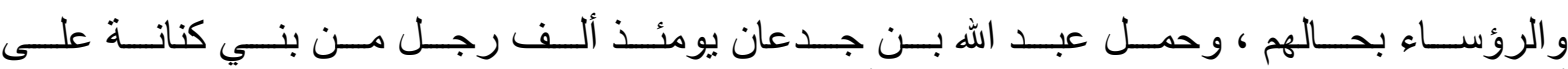

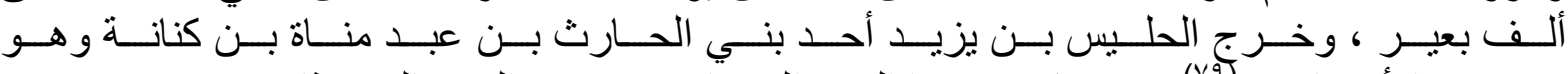

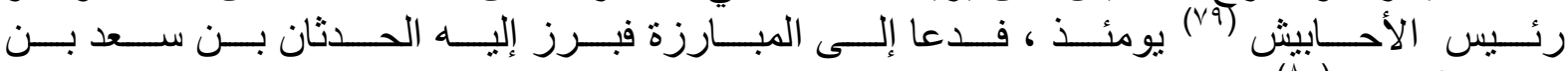

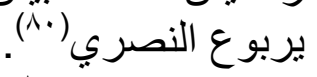

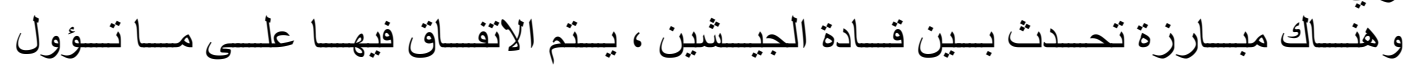

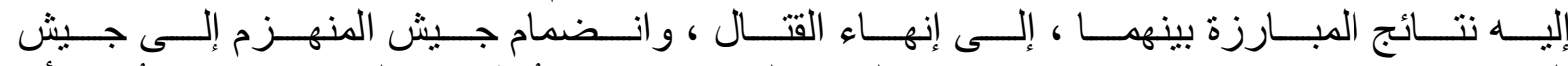

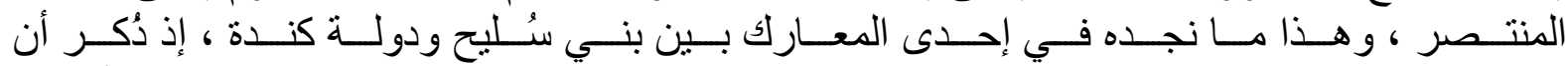

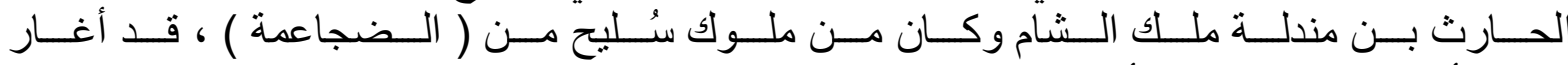

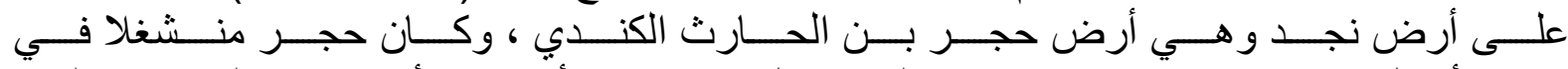

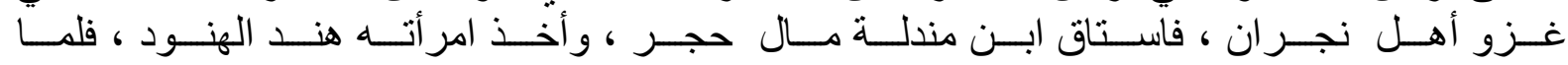

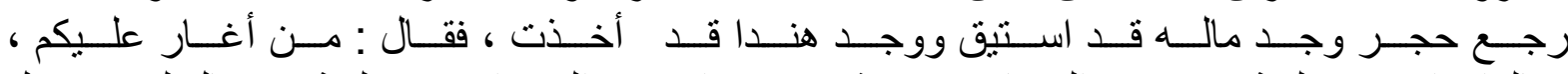

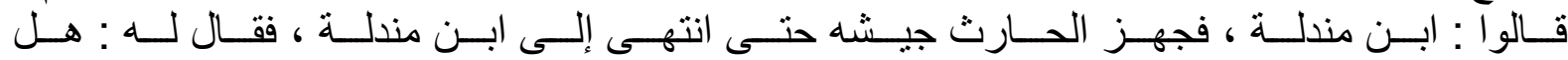

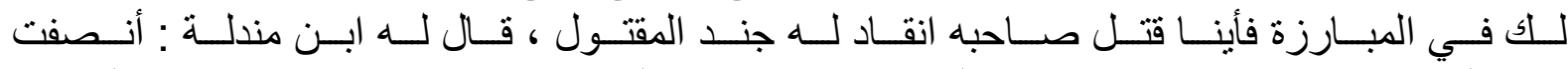

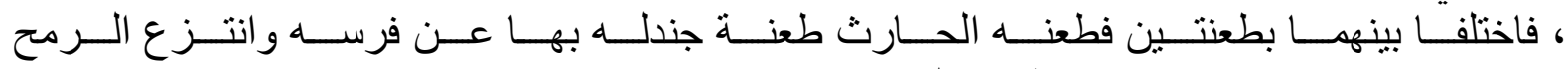

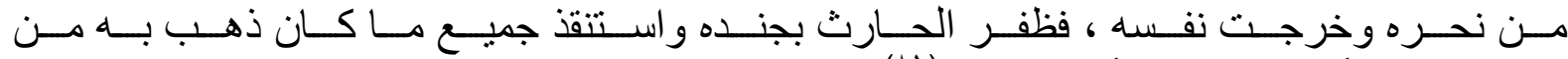

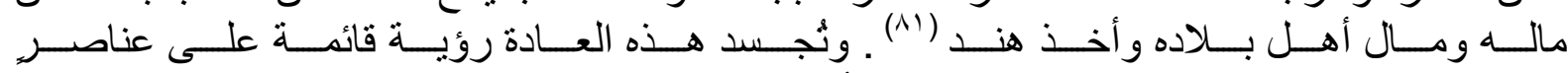

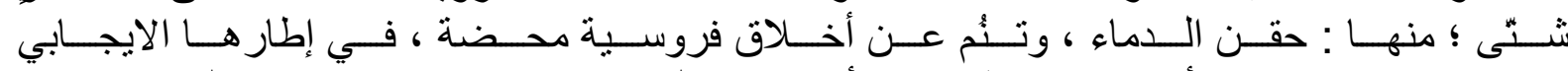

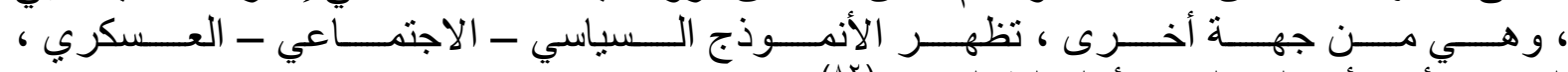

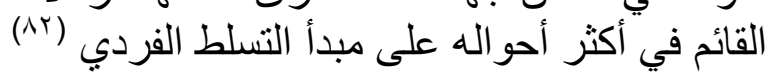

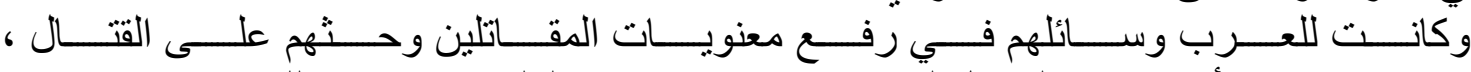

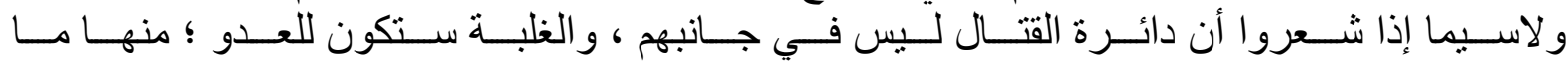

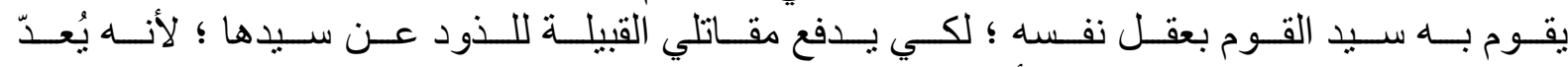

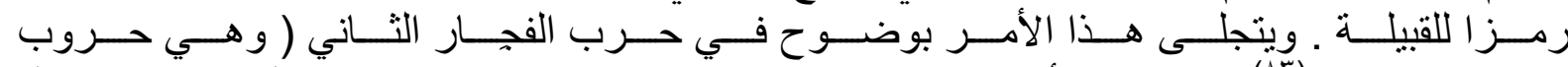

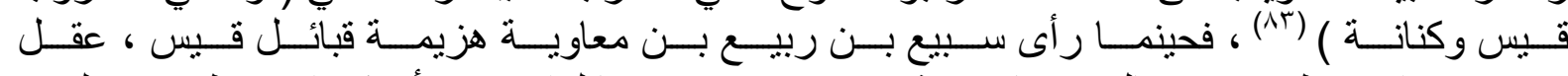

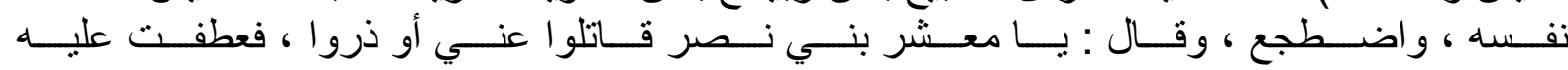

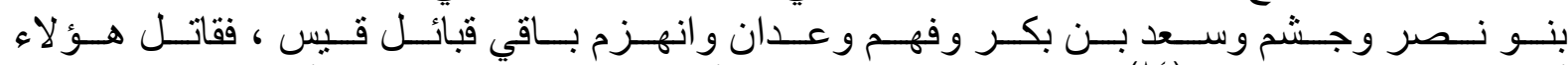

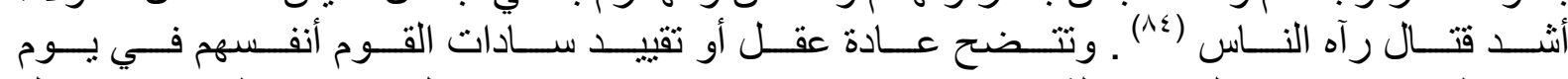

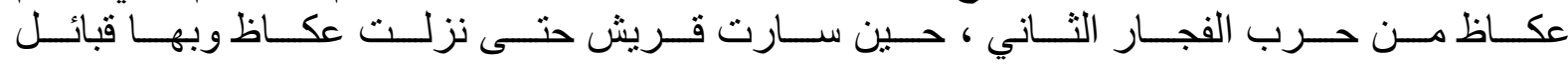

79 - الأحابيش : وهم " بنو الحارث بن عبد مناة بن كنانة ، وبني الهون بن خزيمة : القارة و عضل و الديش وبنو

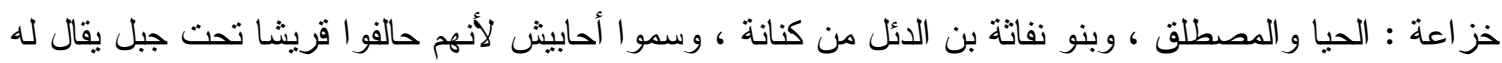

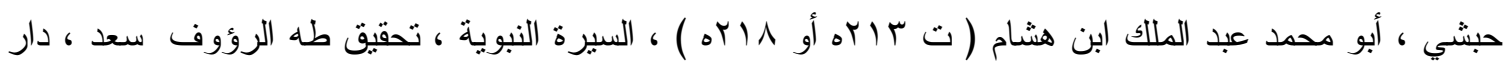

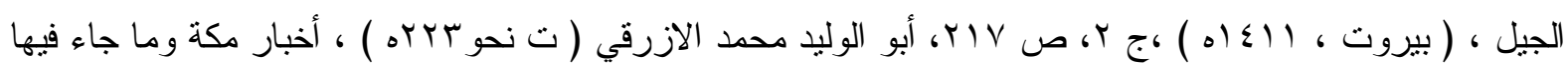

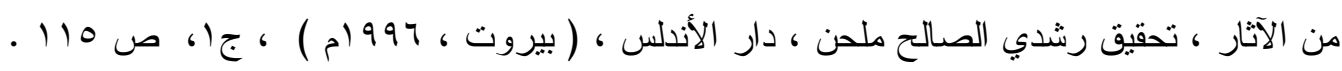
80 81

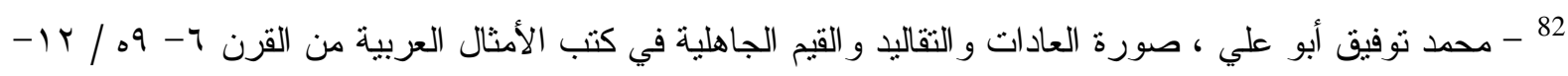

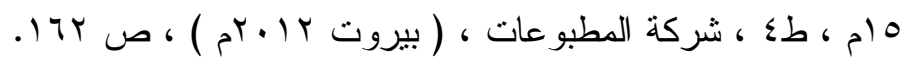
83 84 


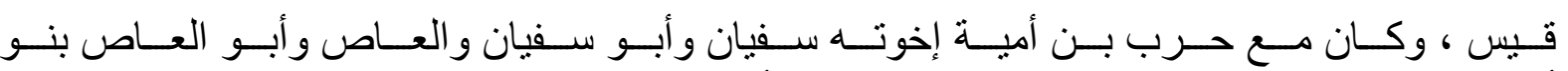

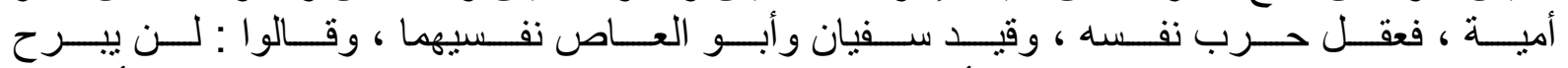

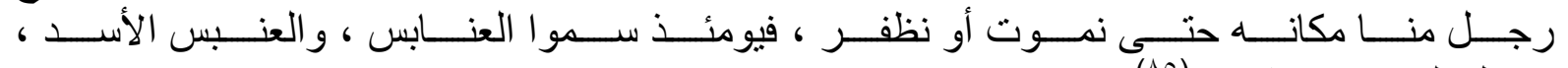
واقتنل الناس قتالا شديدا (دo)

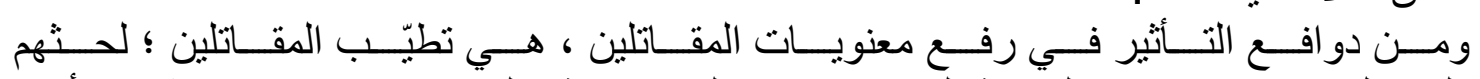

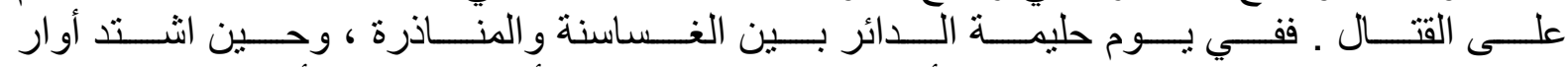

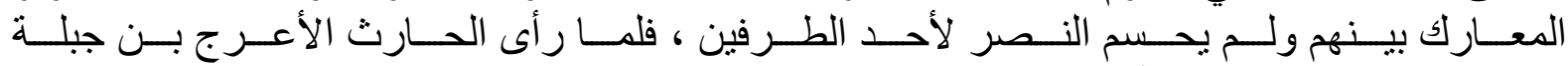

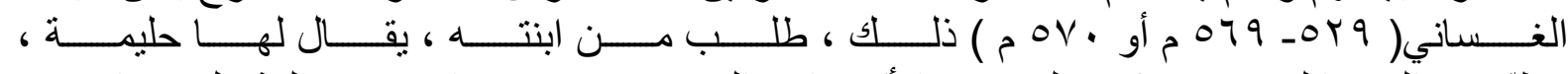

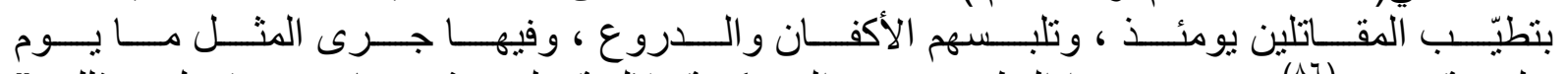

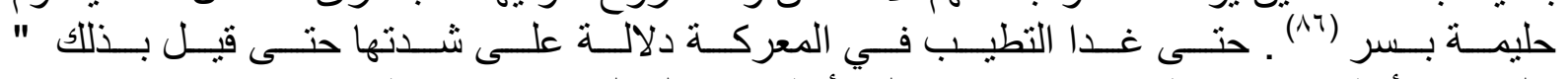

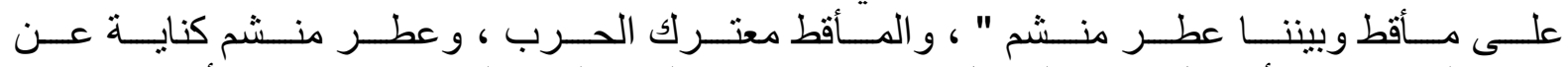

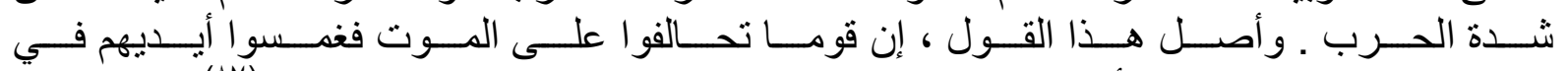

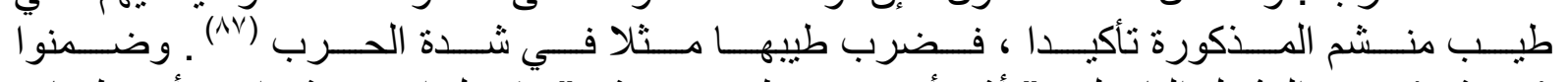

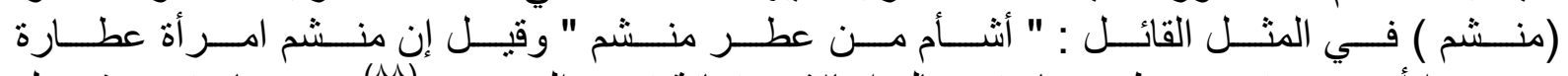

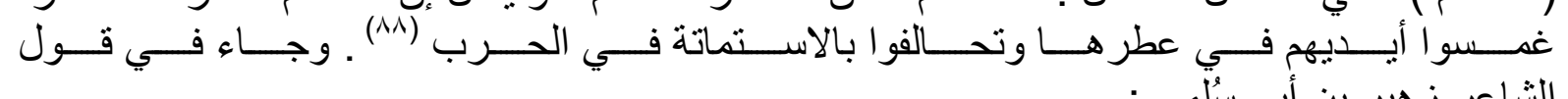

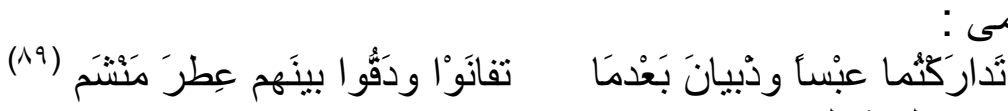
الثاعر زهير بن أبي سُّلمى : وقول المر ار بن علقمة البكري : بلنيان

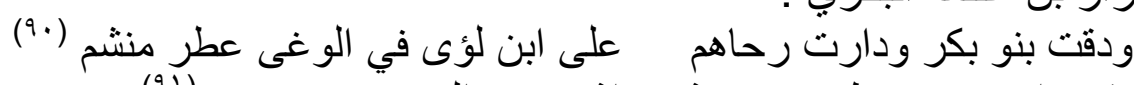

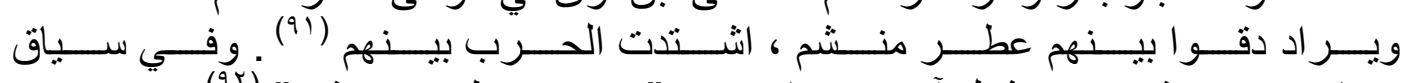

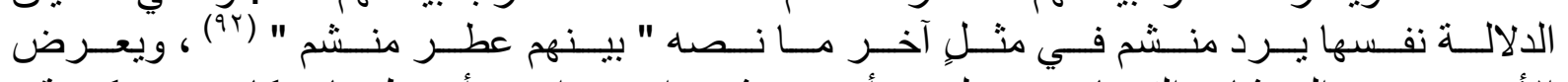

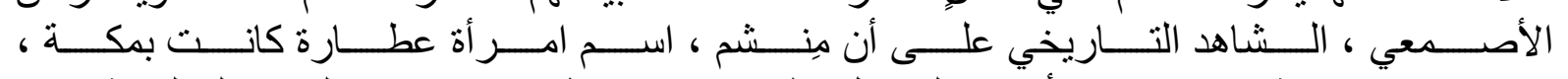

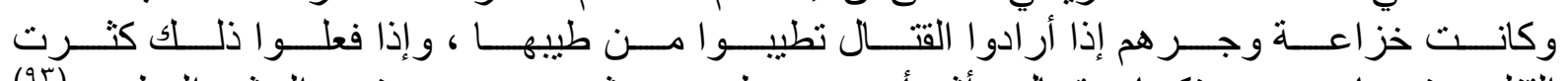

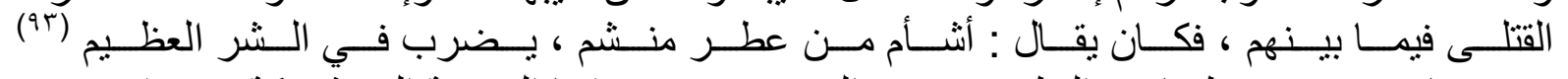

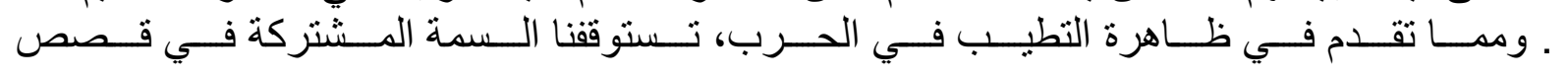

$$
\text { - } 85
$$

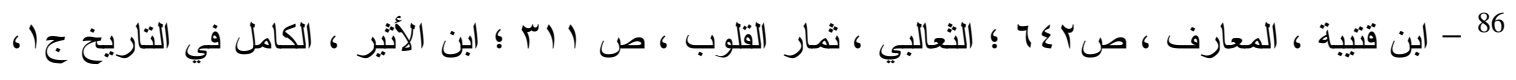
صنr人

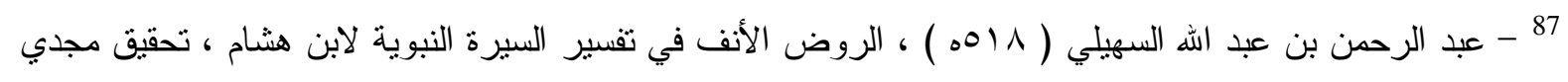

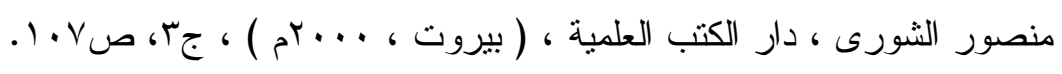

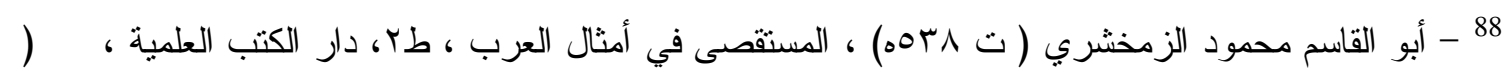

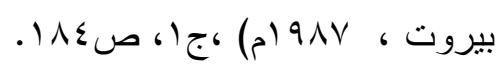

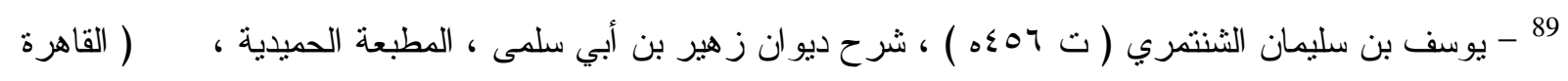

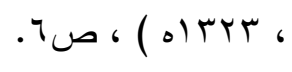

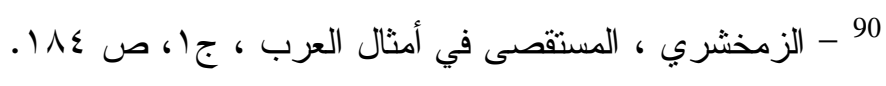

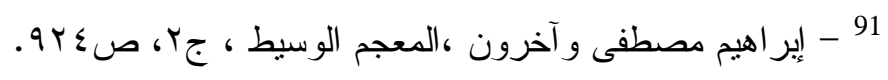

$$
\begin{aligned}
& 92 \\
& 93 \text { - المصدر نفسه و الصفحة . }
\end{aligned}
$$




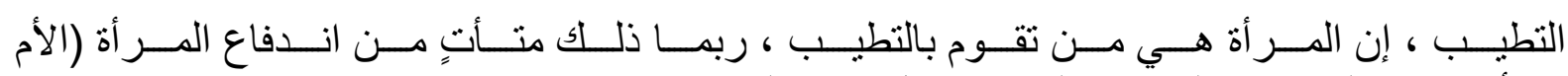

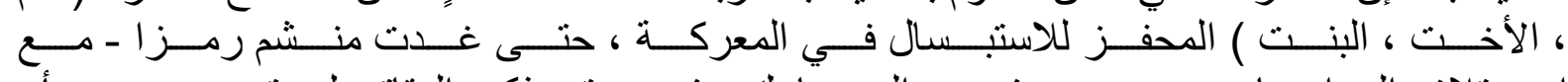

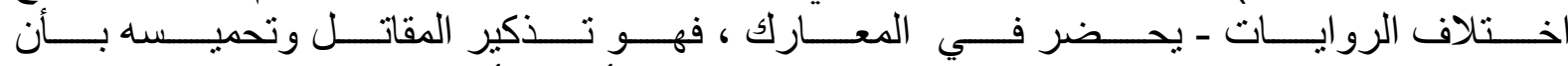

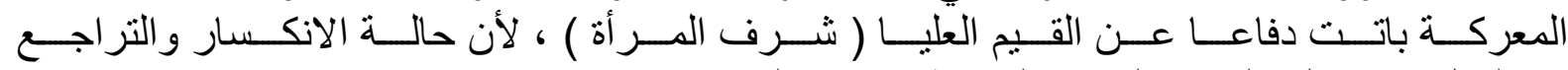

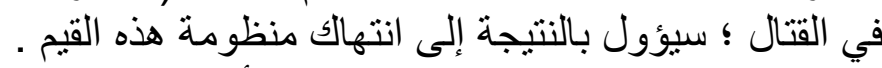

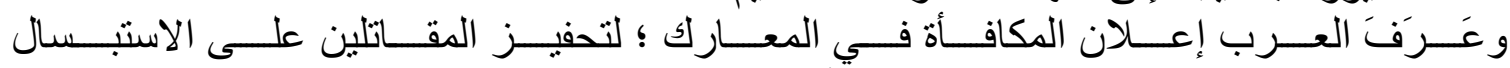

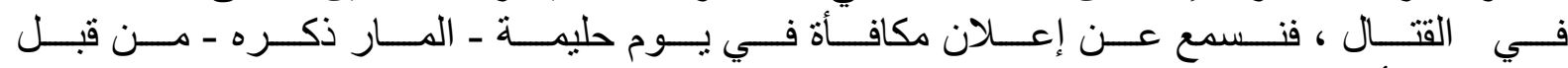

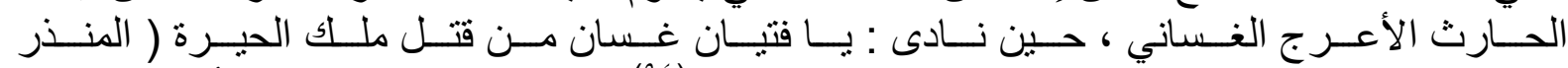

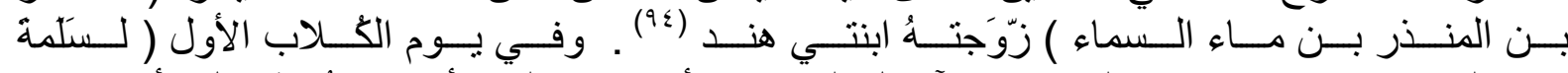

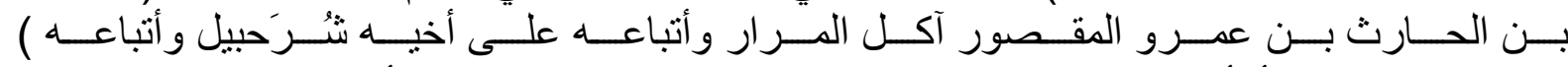

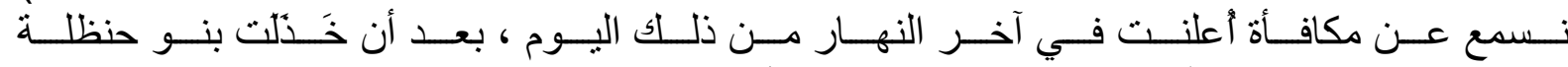

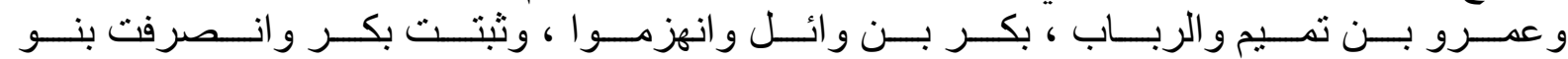

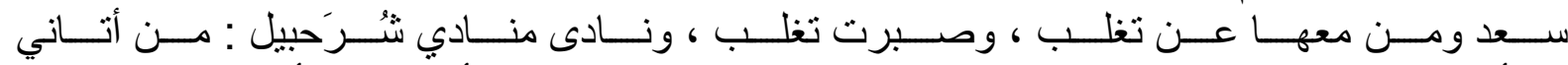

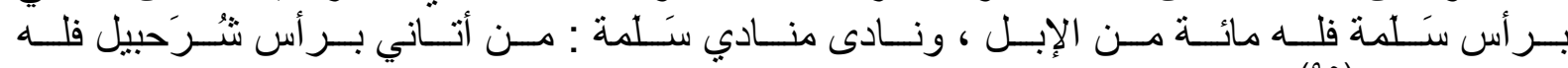
مائة من الإبل (90)

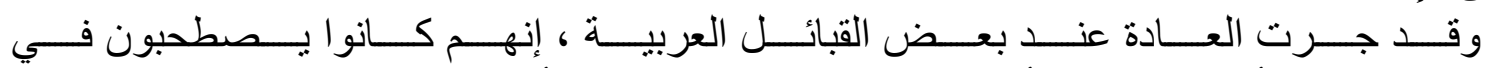

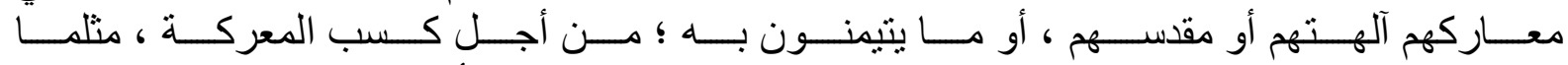

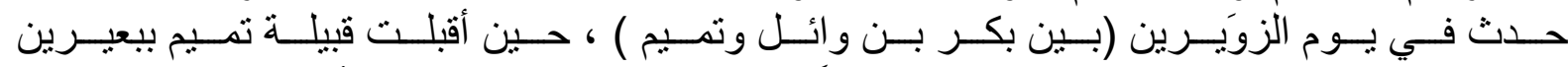

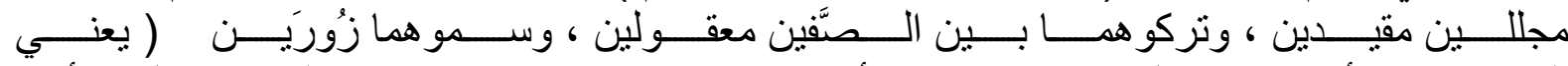

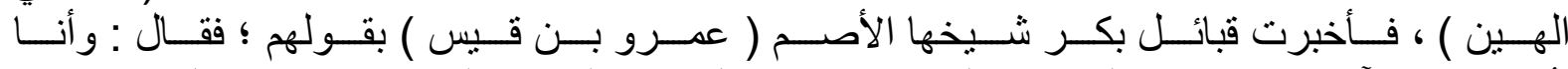

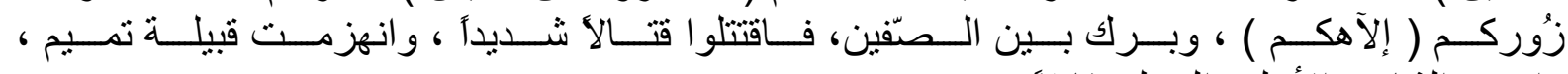

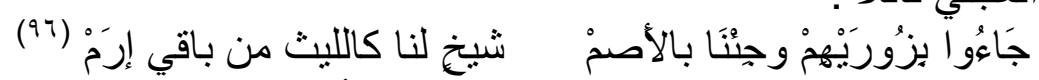
وارجز الثاعر الأغلب العجلي قائلا : مُورئ

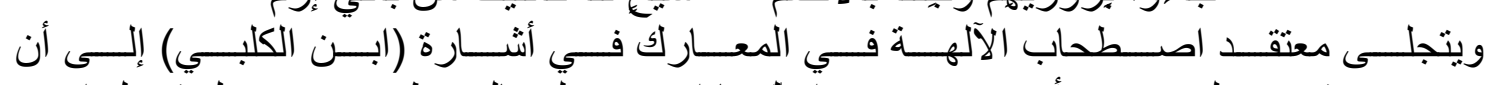

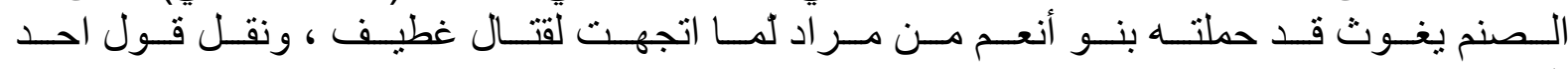

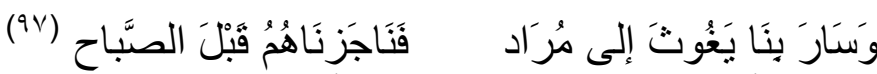

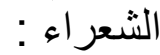

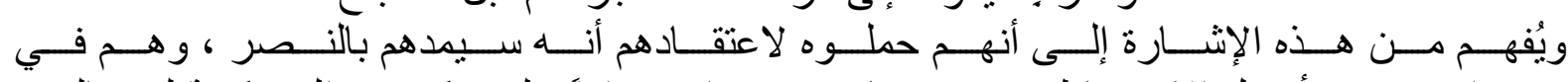

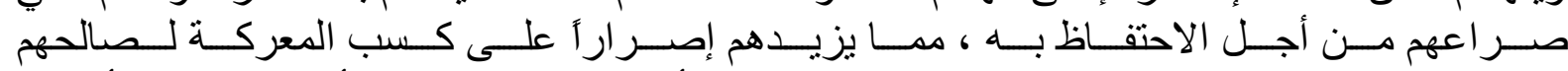

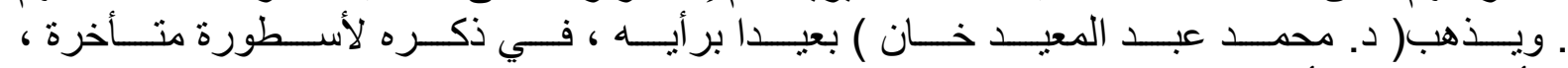

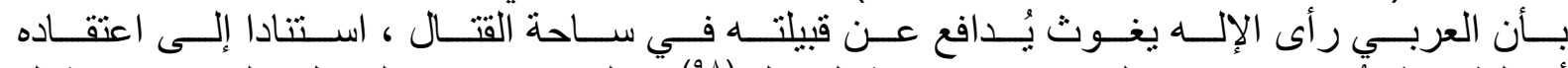

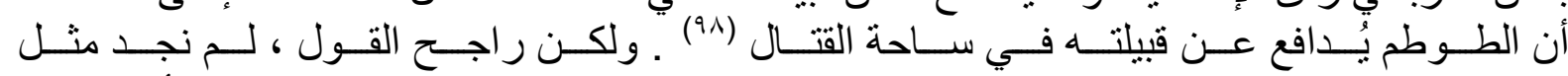

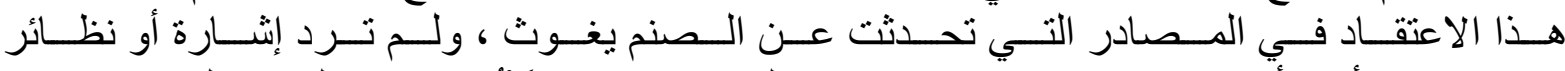

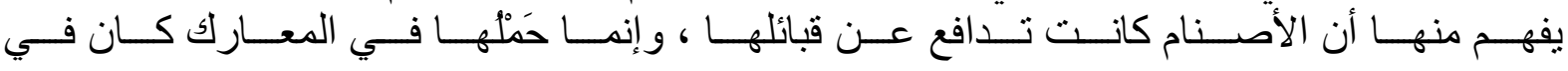

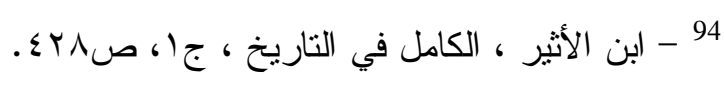

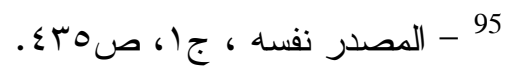

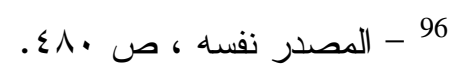

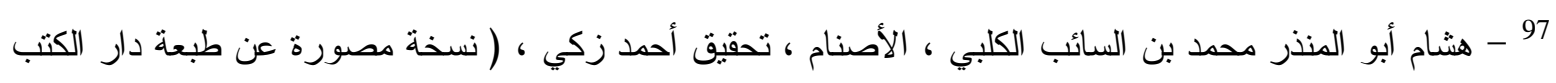

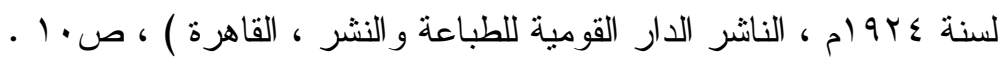

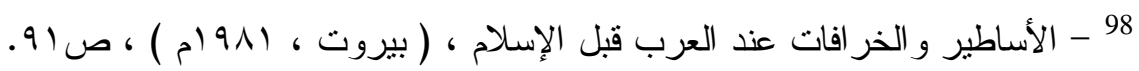




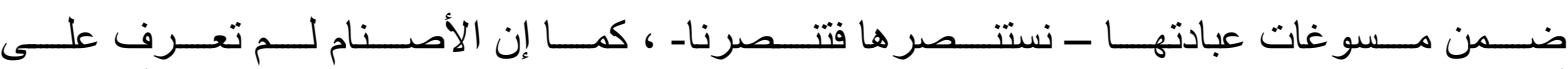

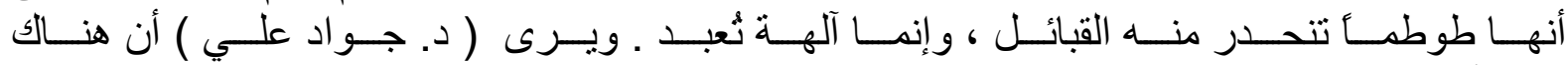

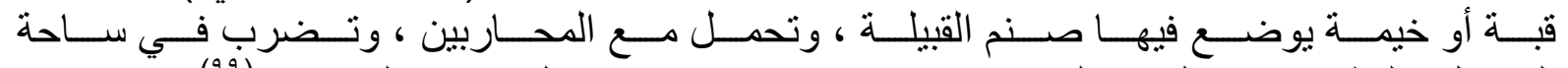

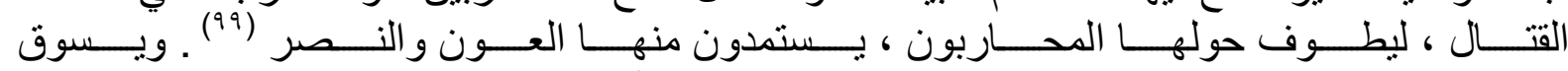

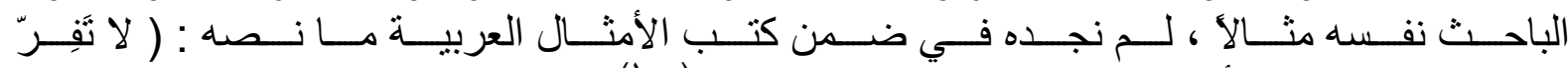

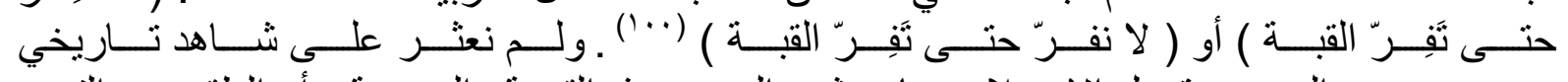

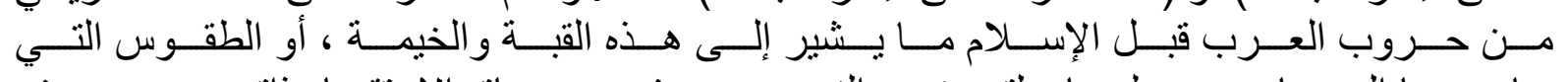

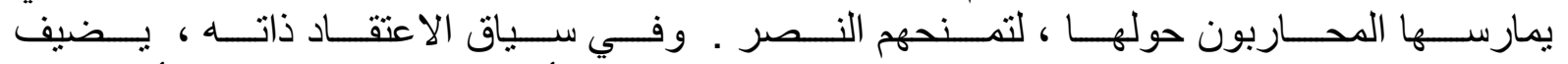

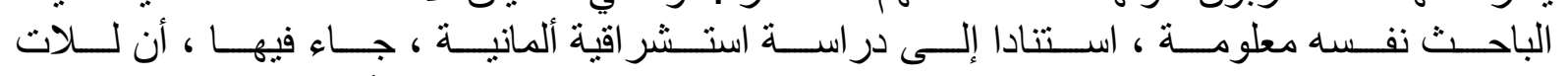

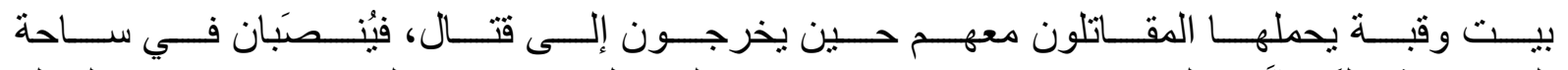

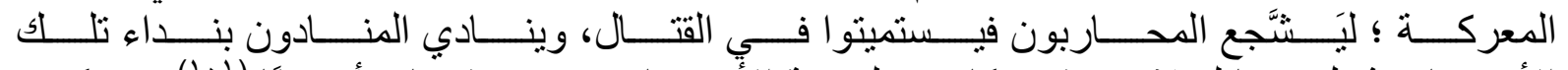

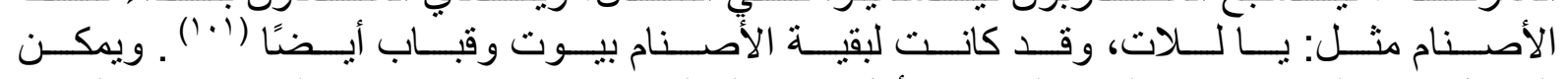

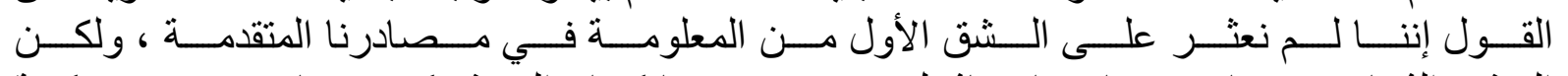

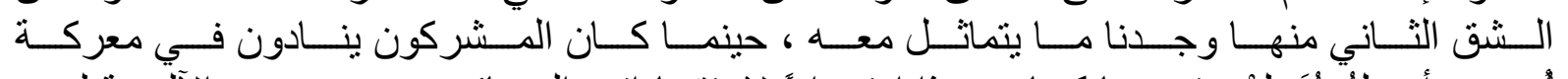

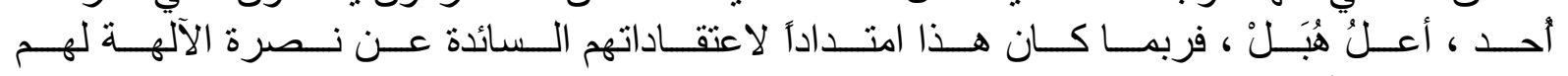

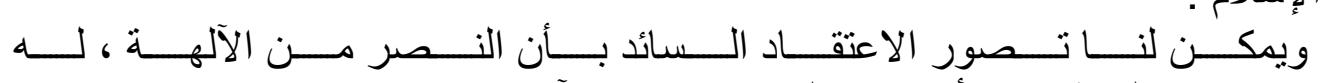

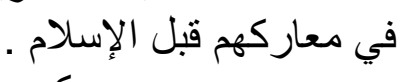

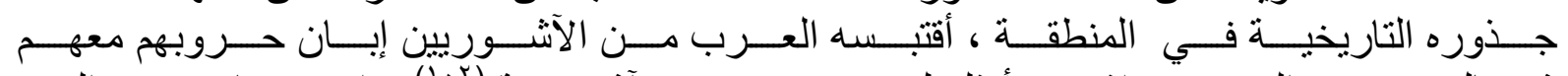

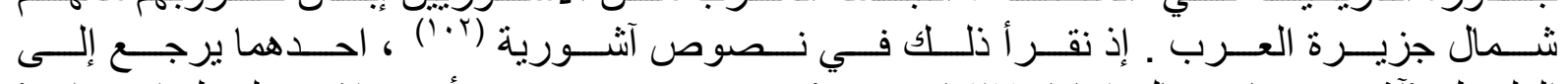

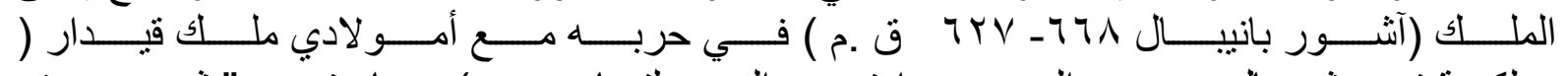

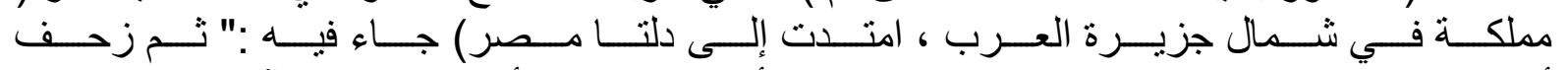

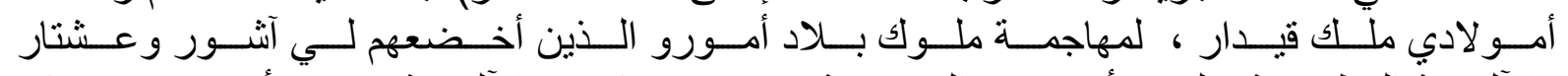

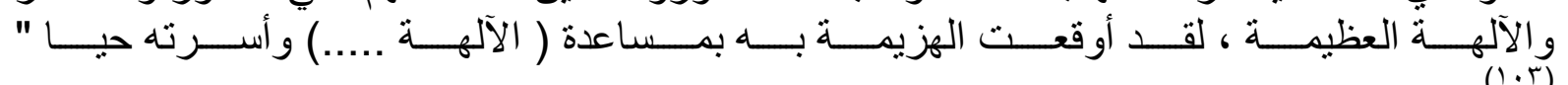
().r)

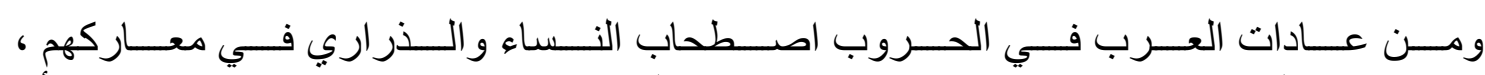

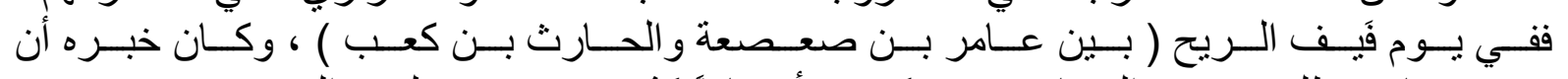

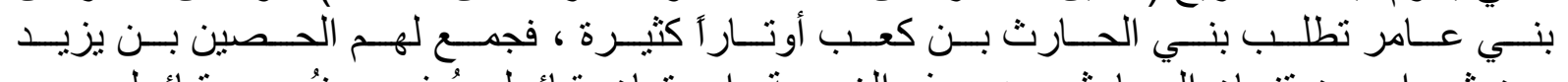

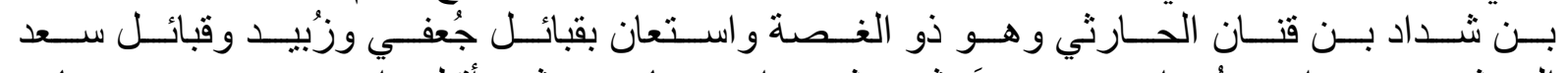

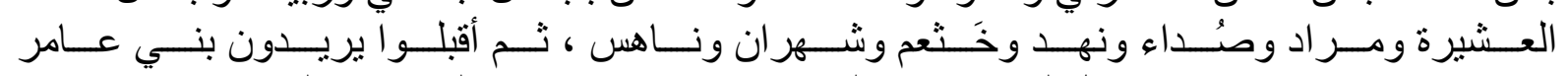

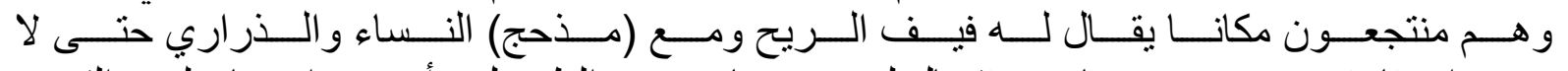

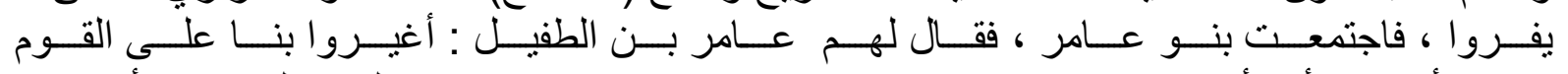

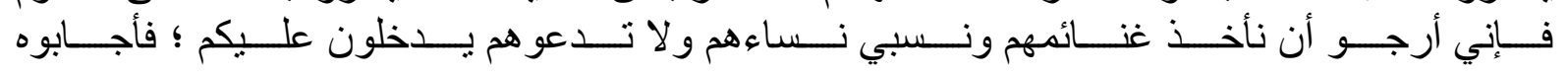

$$
99
$$

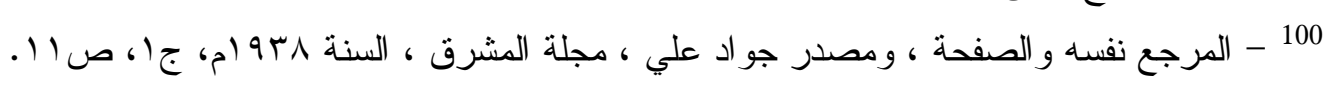

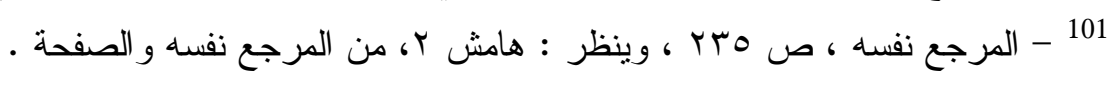

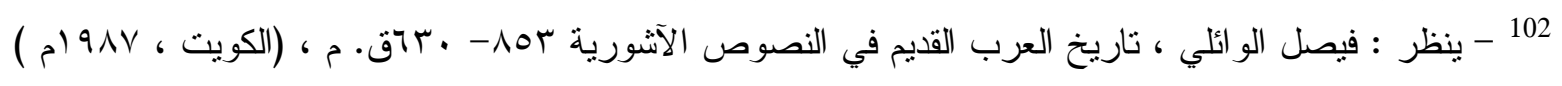

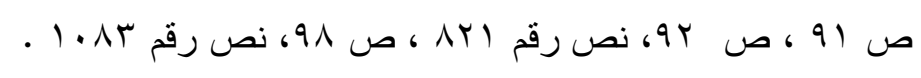

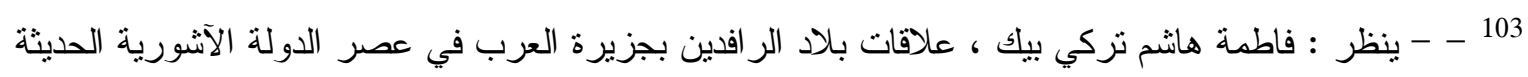

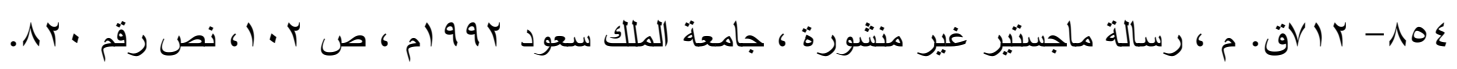




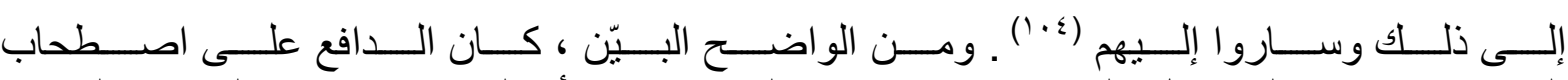

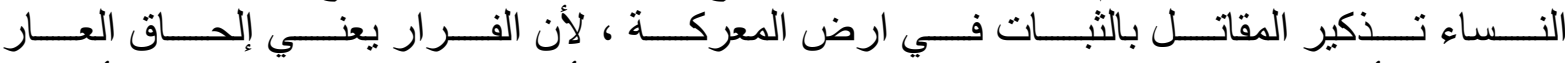

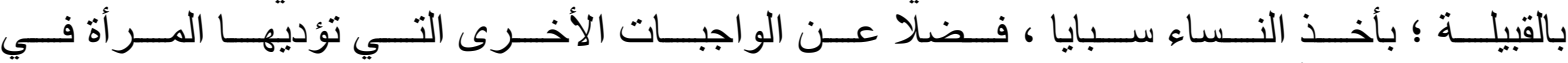

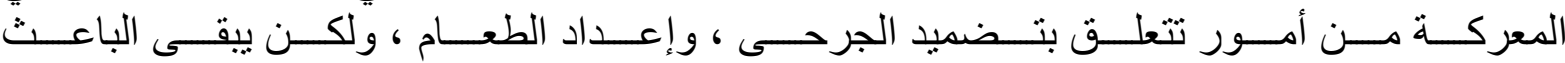

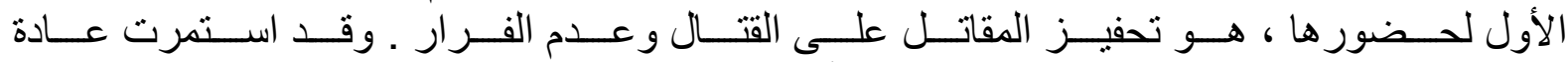

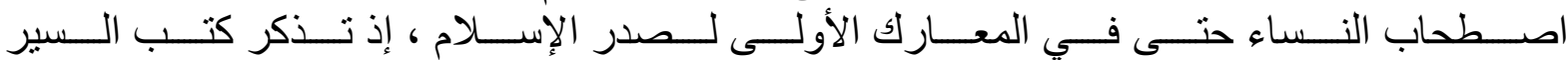

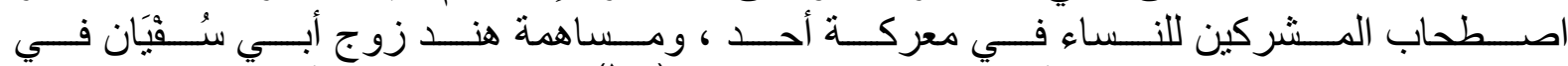

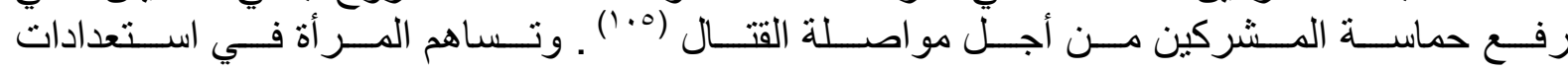

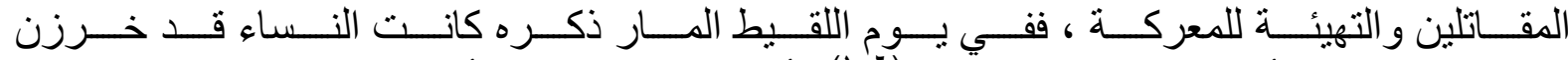

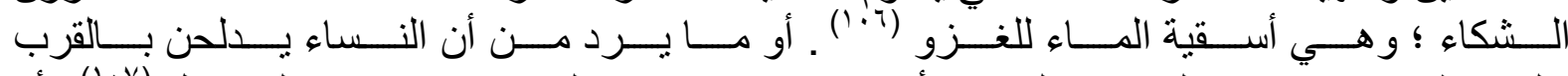

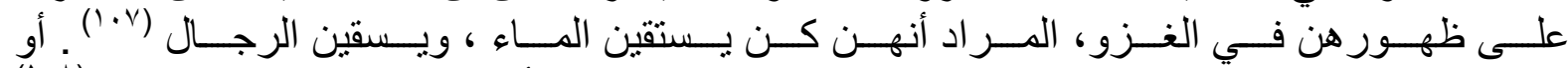

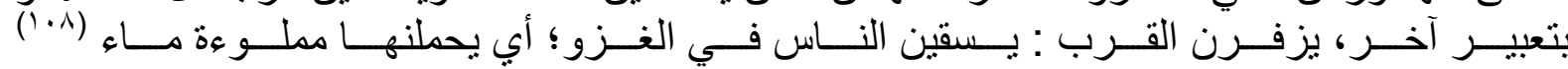

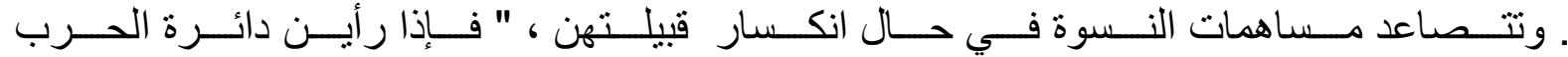

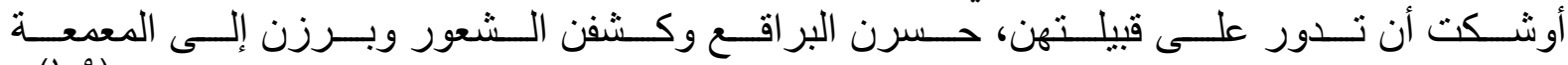

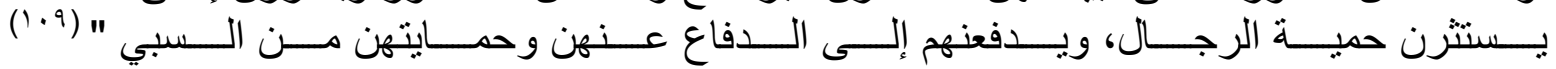
ونتلمس هذه الصورة في قول فارس مذحج عمرو بن معد يكرب الزئي الزبيدي :

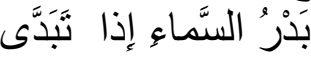

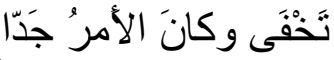

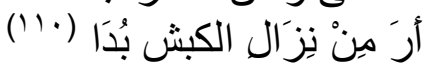

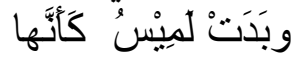

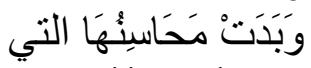

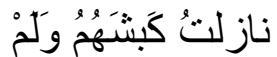

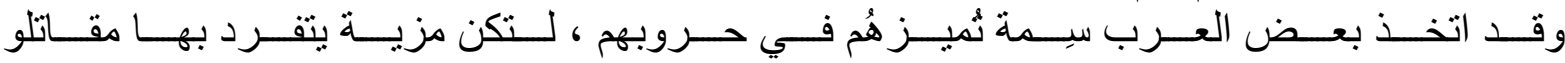

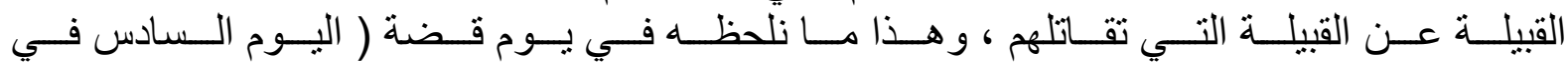

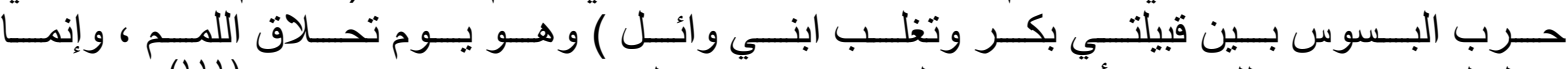

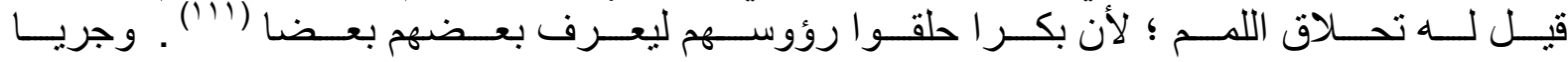

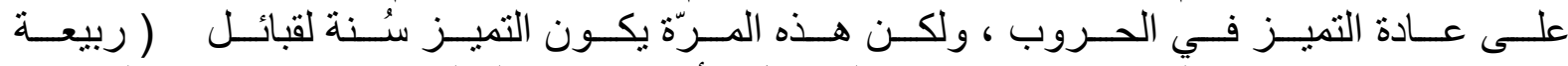

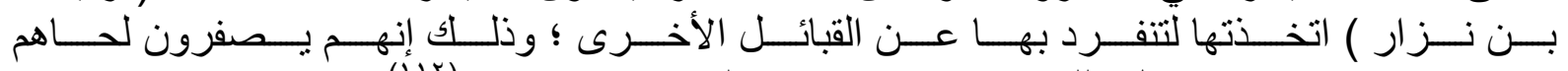

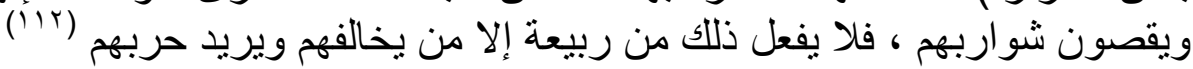

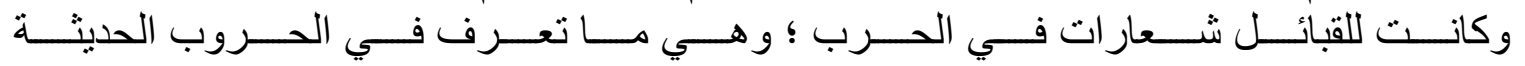

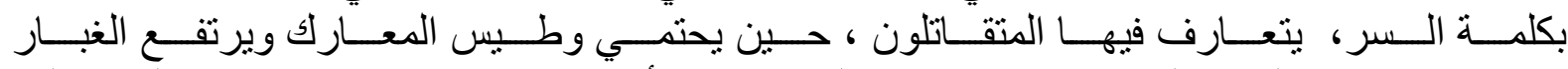

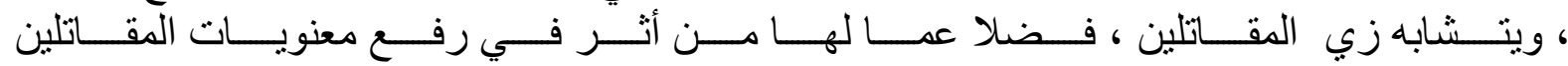

104

105

106

107

108

109

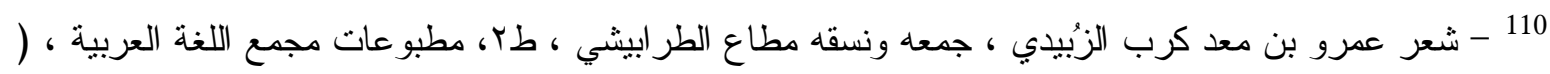

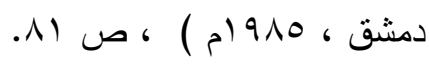
111 112 


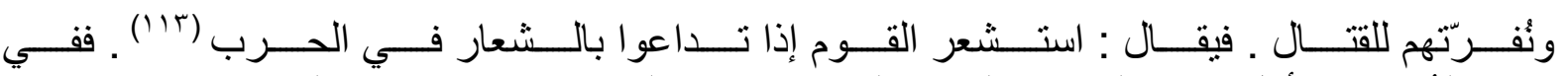

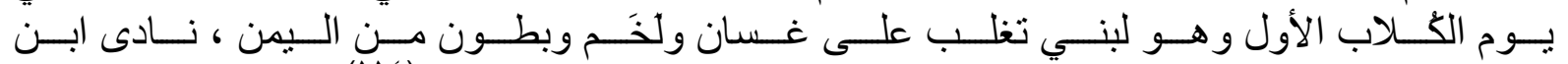

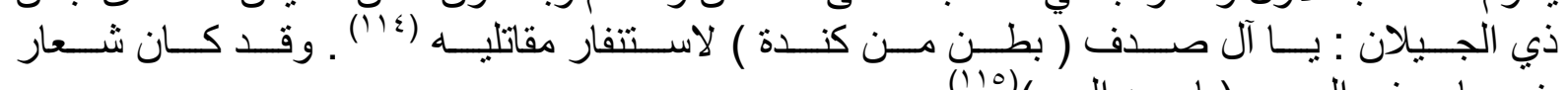

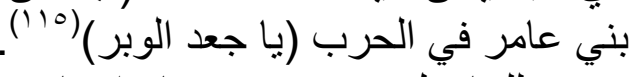

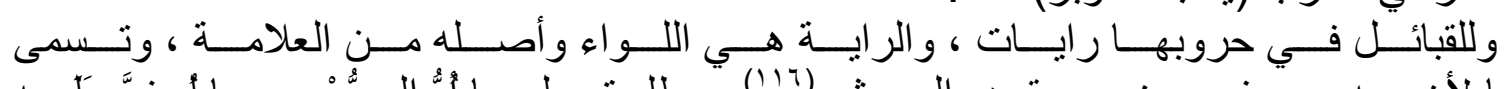

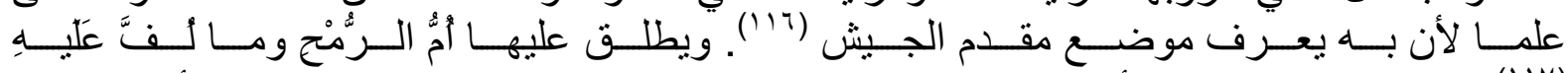

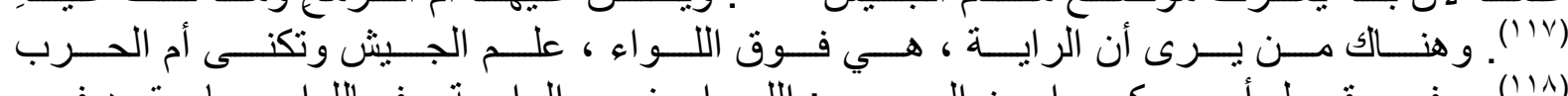

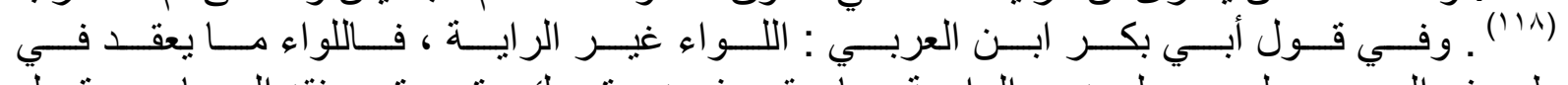

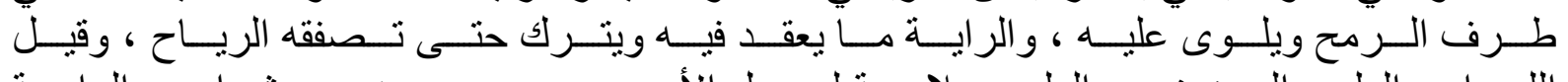

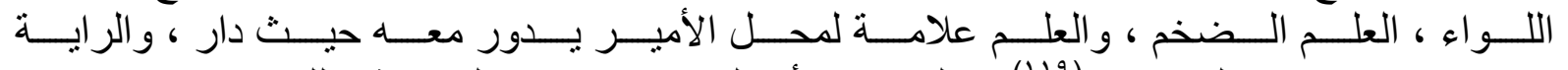

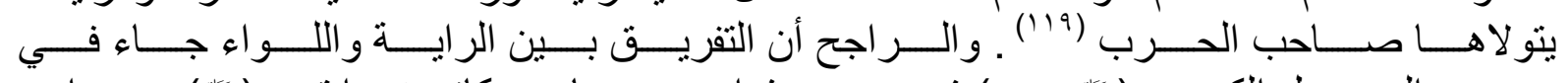

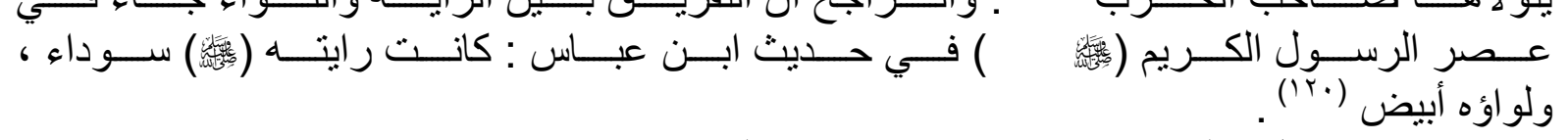

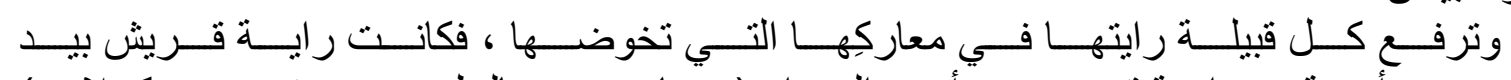

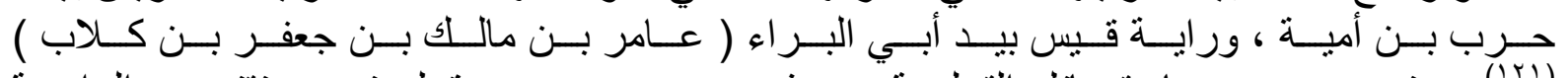

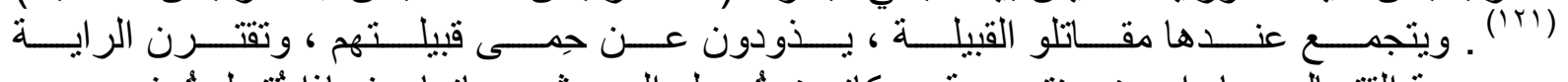

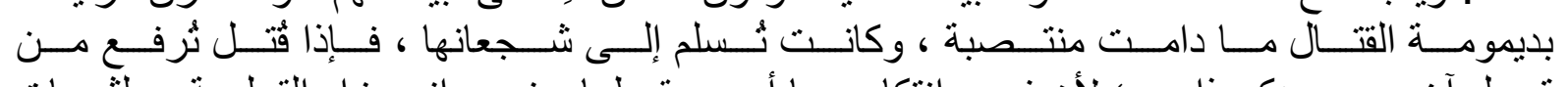

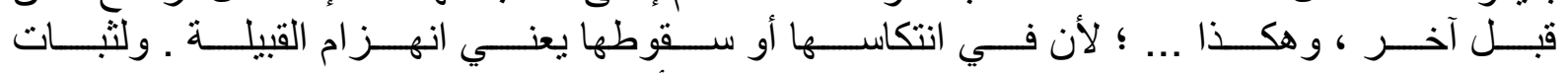

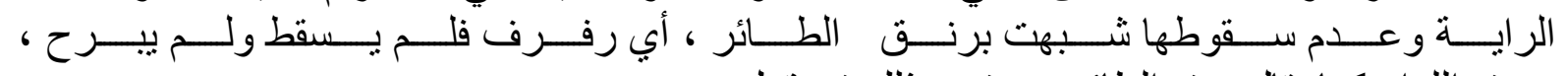

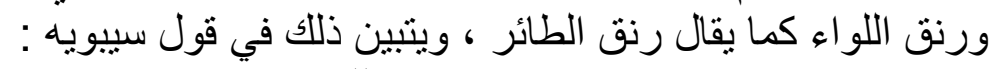

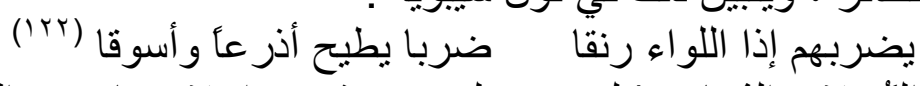

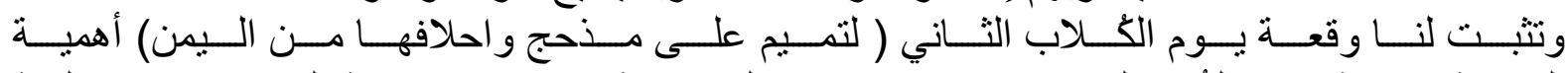

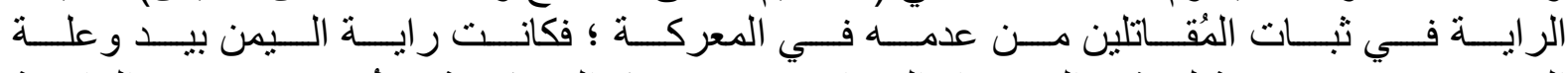

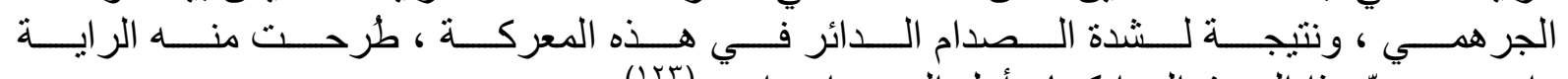

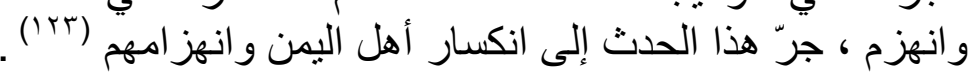

113 114 115

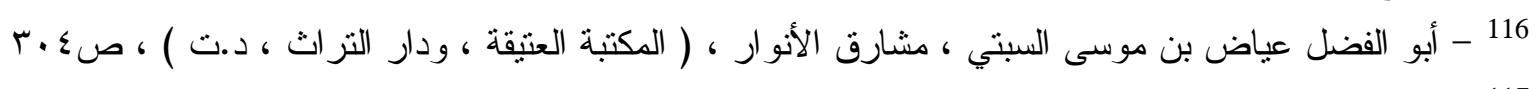

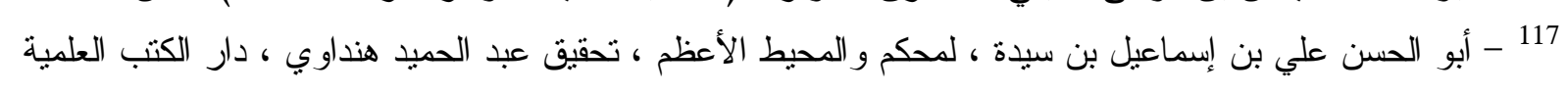

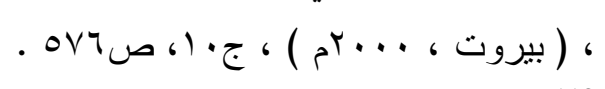

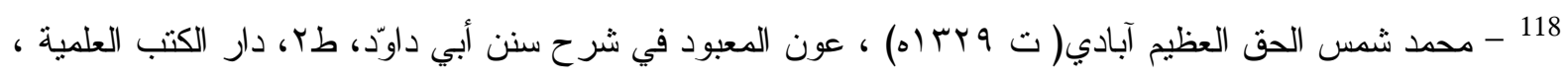

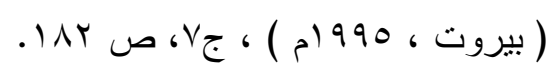

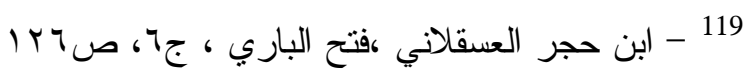

$$
\begin{aligned}
& 120
\end{aligned}
$$

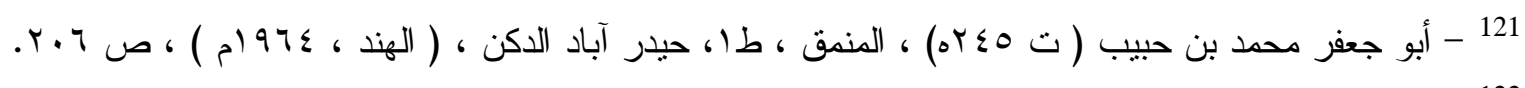
122

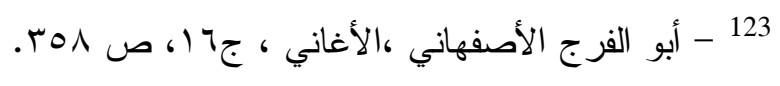




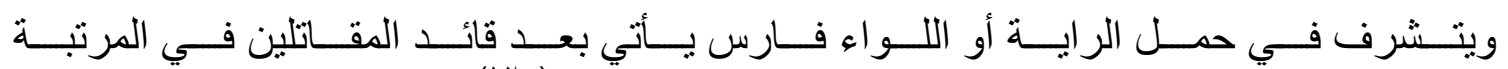

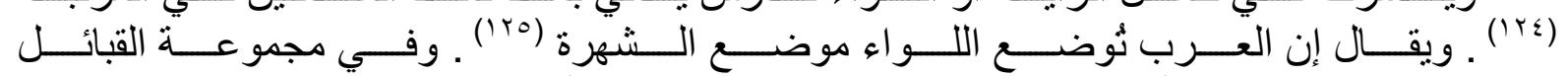

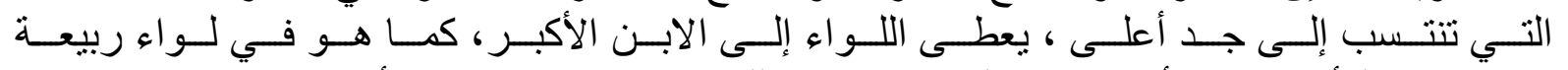

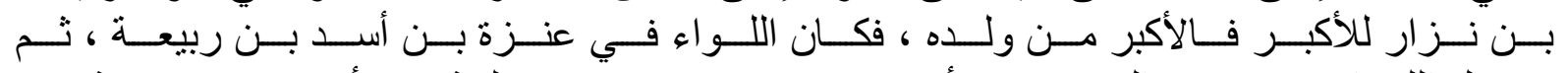

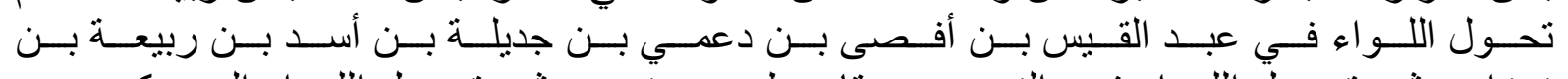

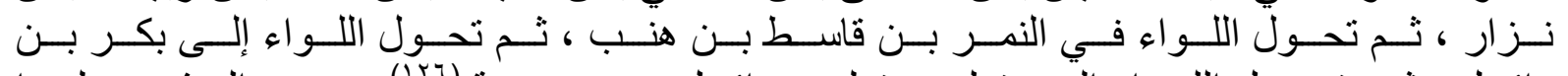

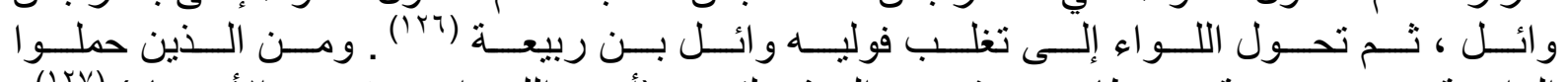

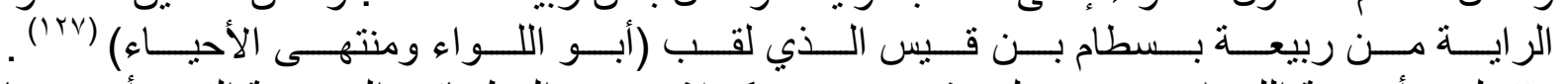

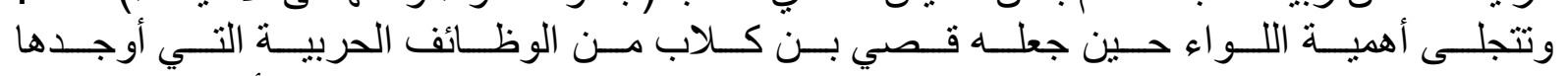

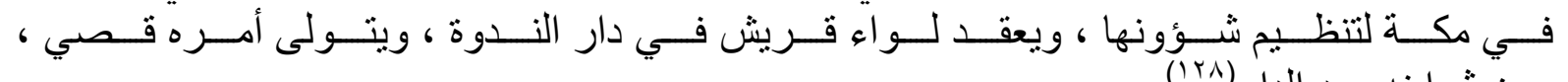

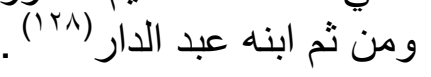

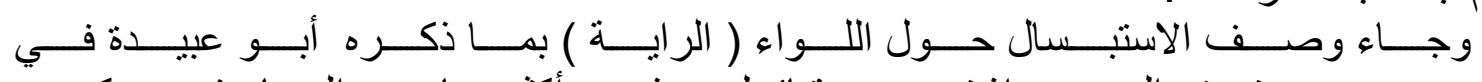

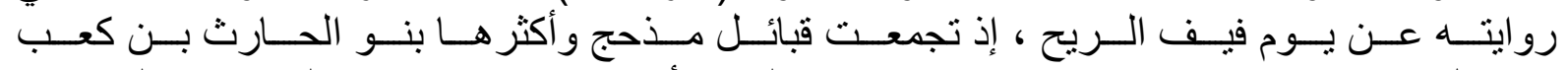

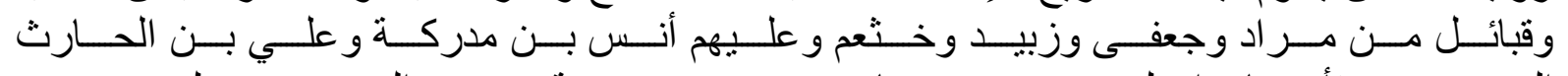

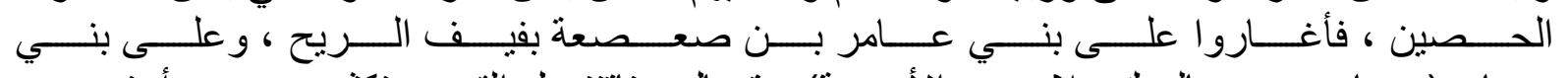

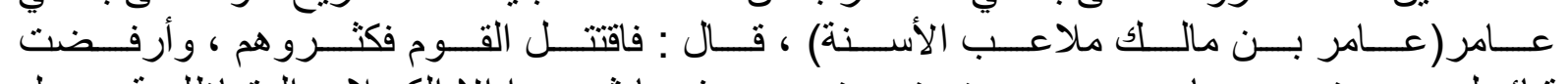

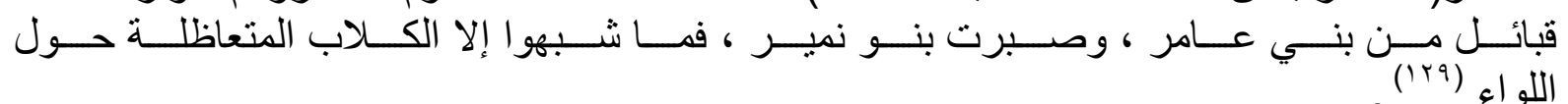

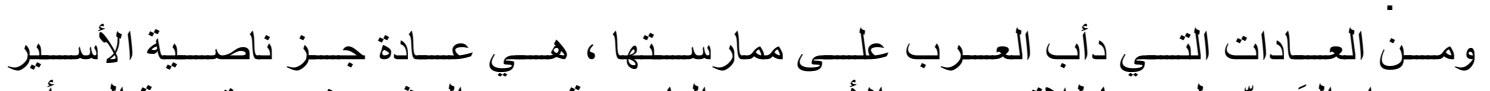

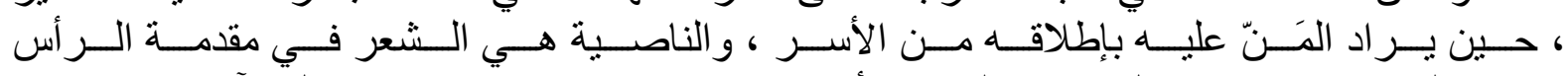

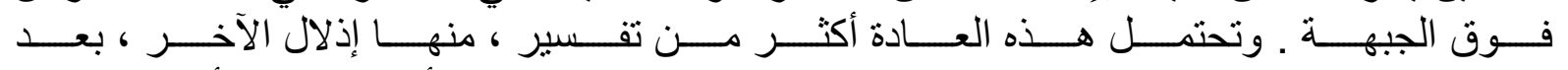

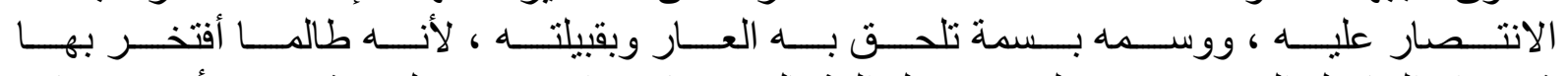

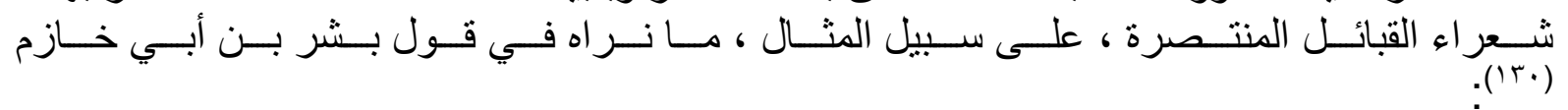

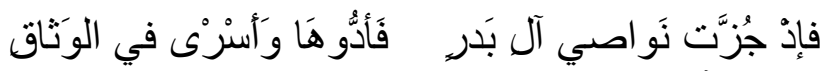

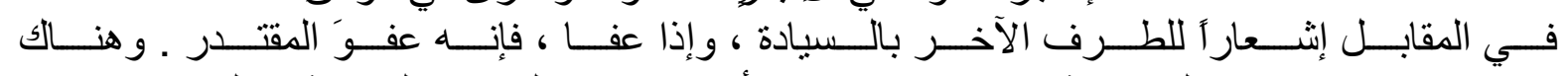

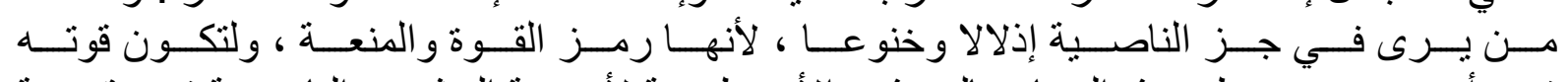

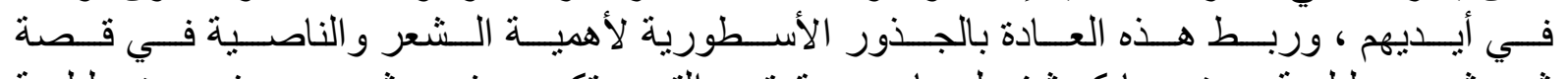

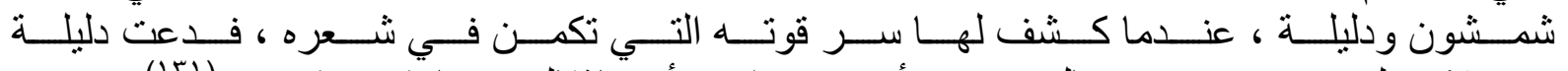

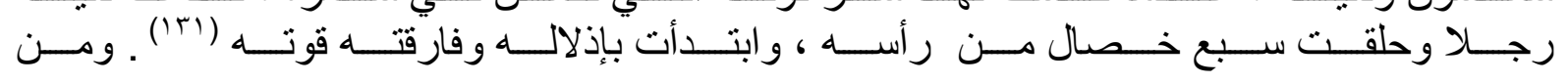

$$
\begin{aligned}
& 124 \text { - المصدر نفسه ، جV، ص 070، ج 9، ص .r ج. }
\end{aligned}
$$

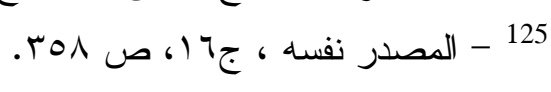

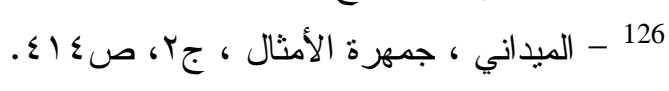

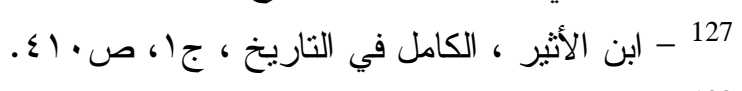

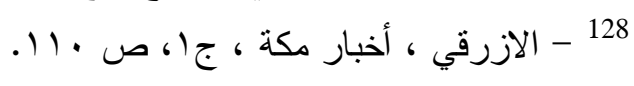

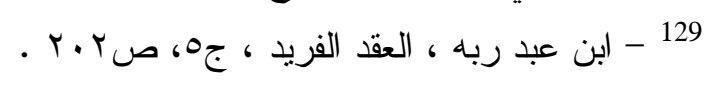

130 - ديوان بشر بن أبي خازم الأسدي ، قدم له وشرحه مجيد طر اد ، دار الكتاب العربي ،(بيروت ، ـ99 ام ام ) ص 


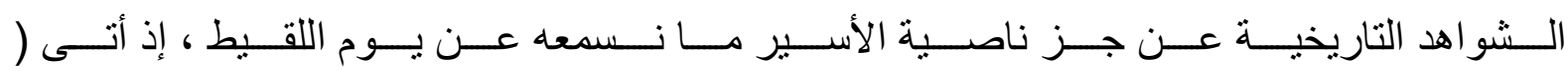

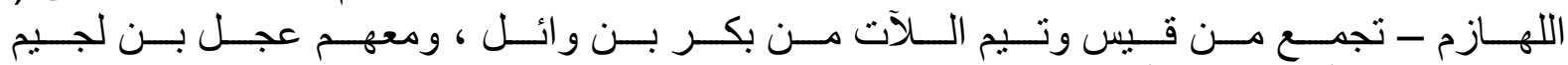

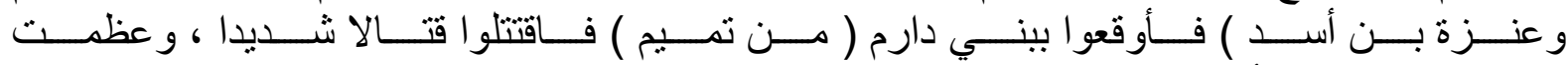

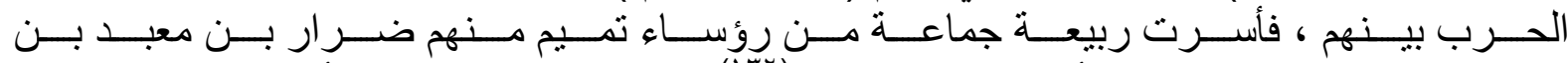

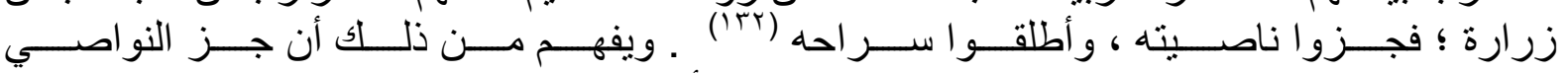

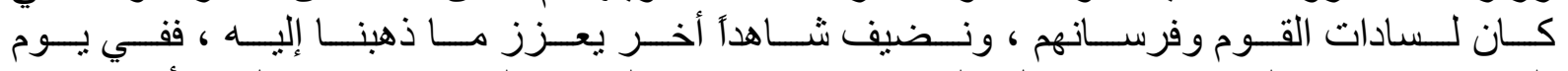

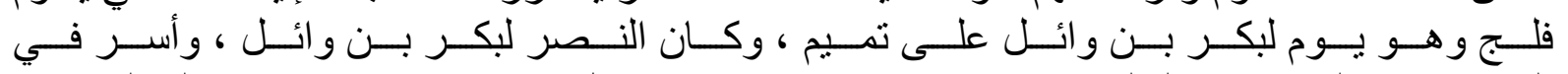

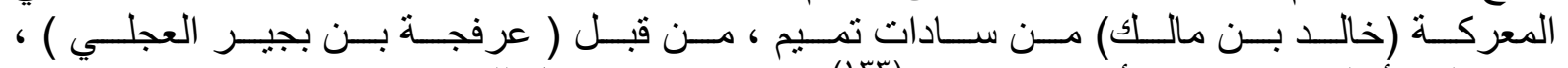

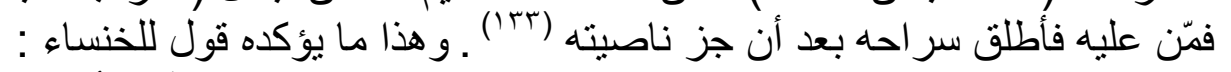

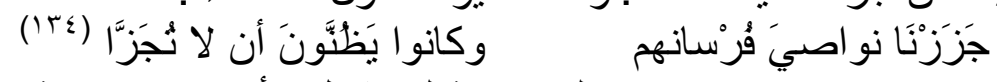

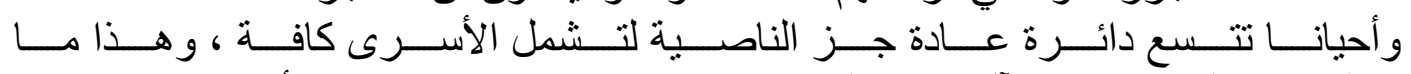

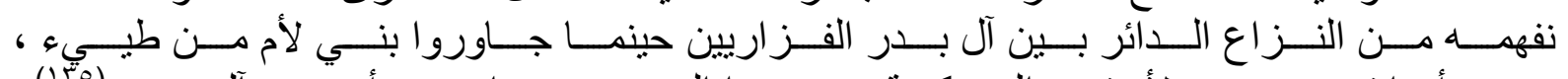

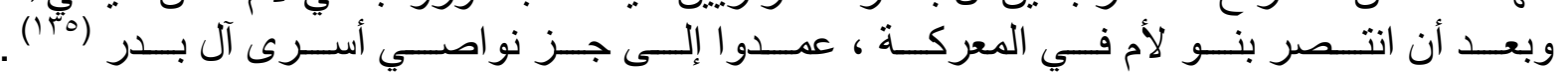

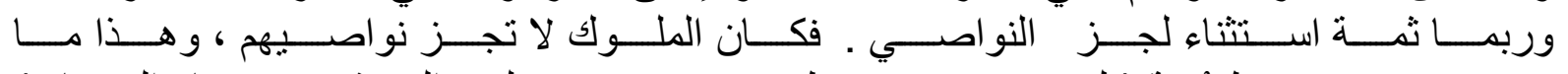

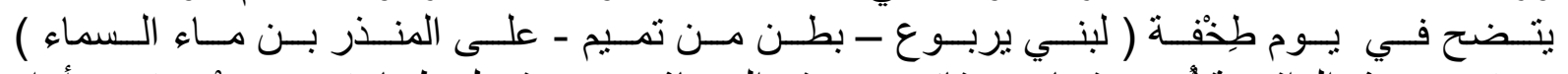

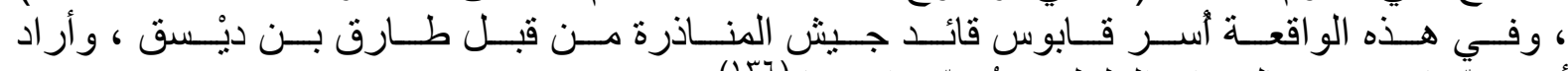

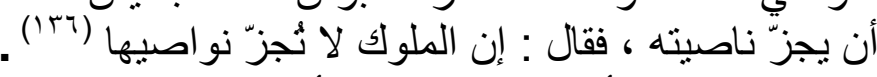

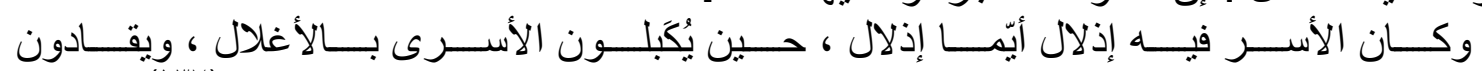

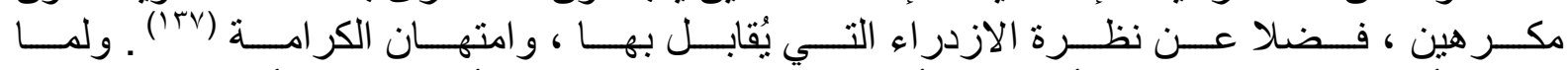

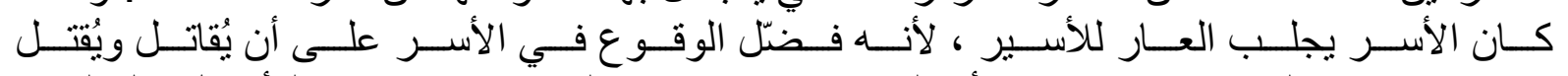

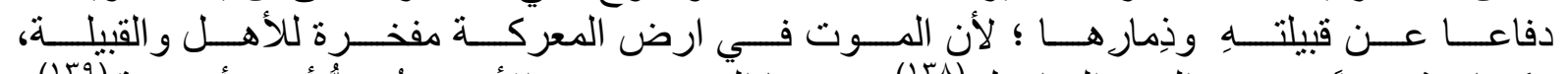

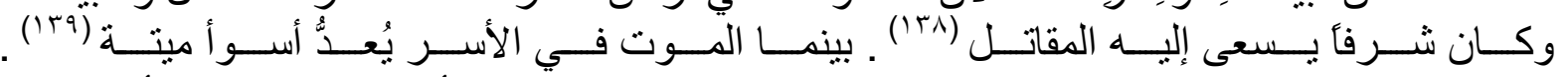

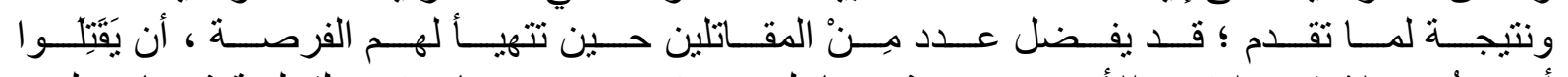

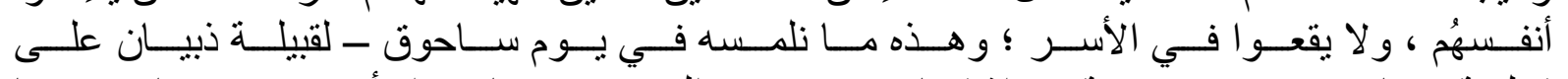

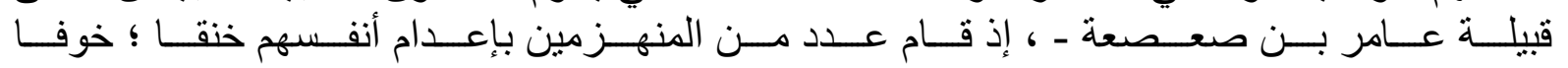

132 133 134

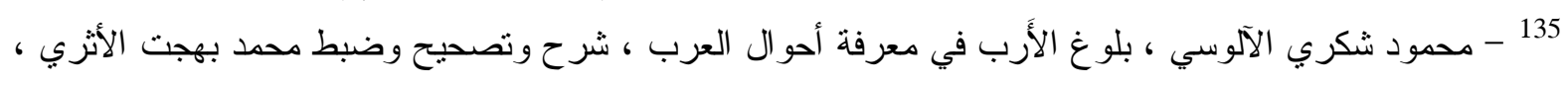

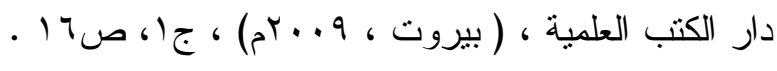

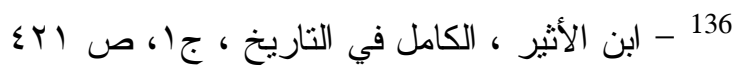

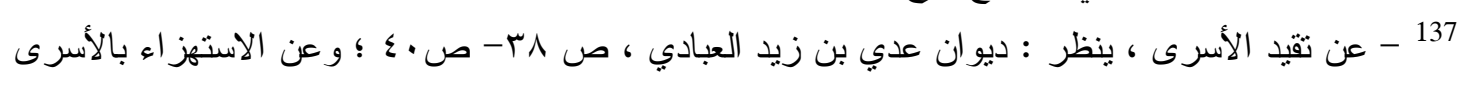

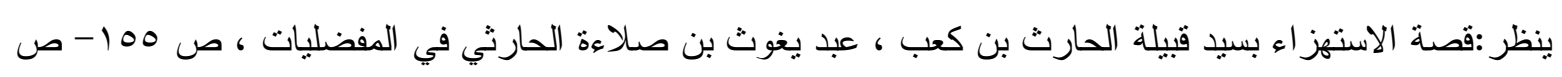

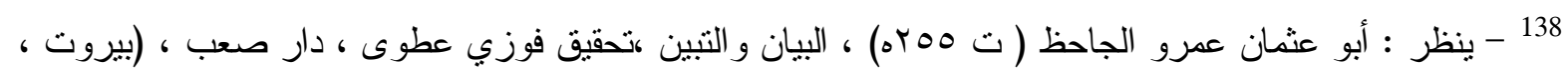

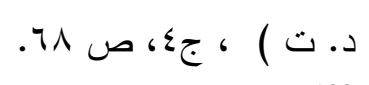

139 - ينظر : ديوان امرئ القيس ، تحقيق عبد السلام محمد هارون ، ( القاهرة ، د. ت ) ، ص. . ب. 


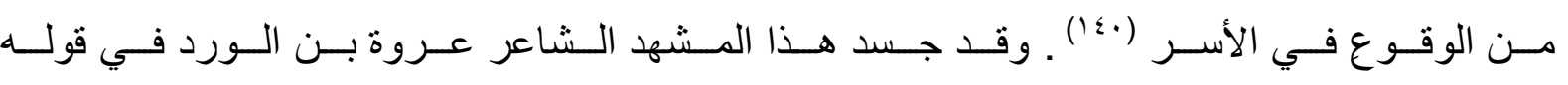

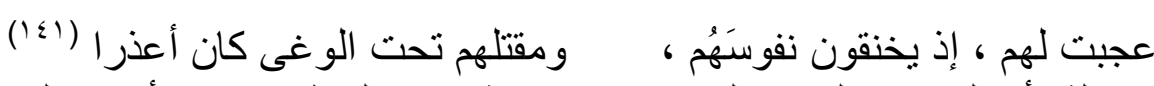

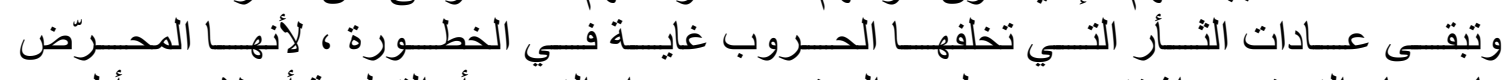

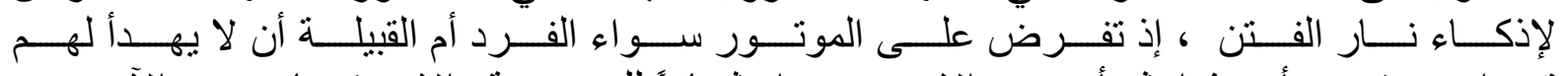

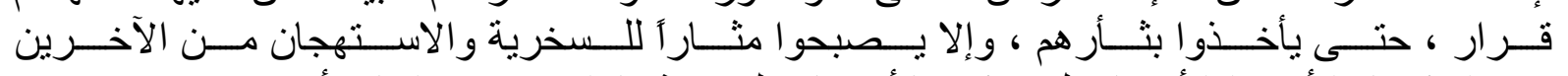

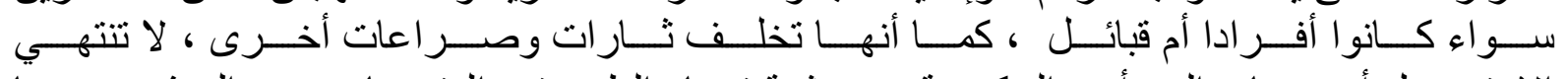

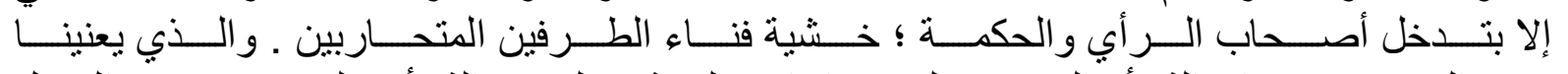

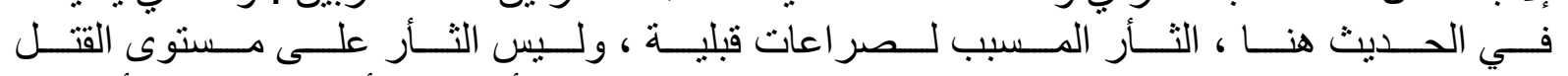

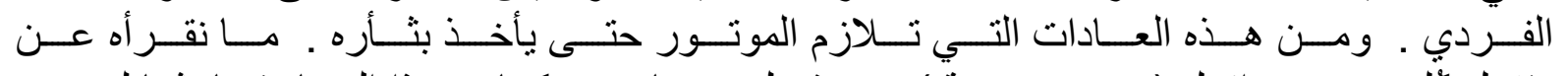

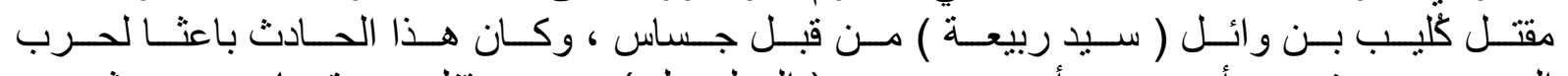

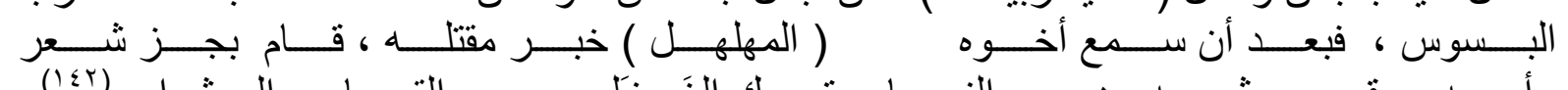

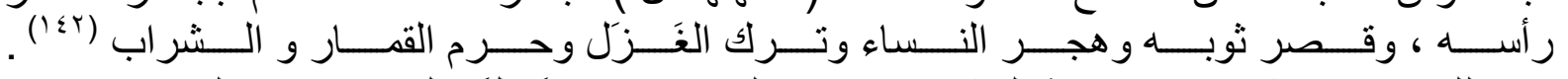

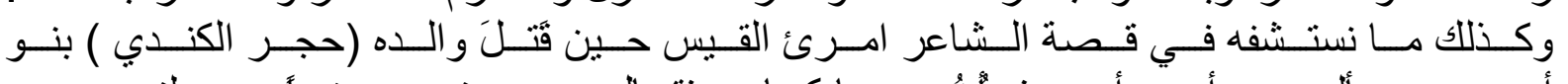

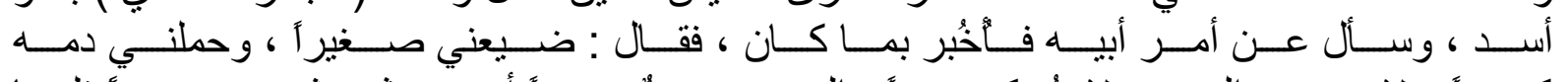

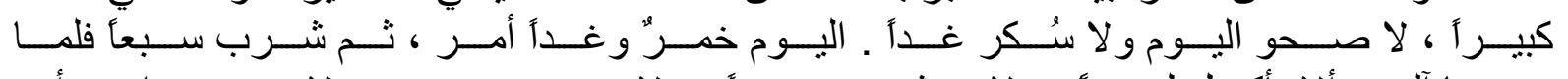

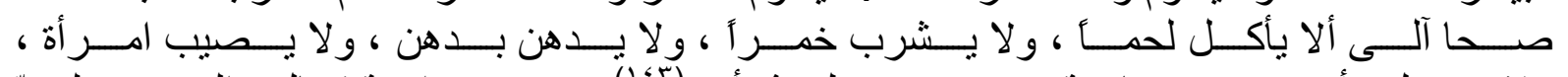

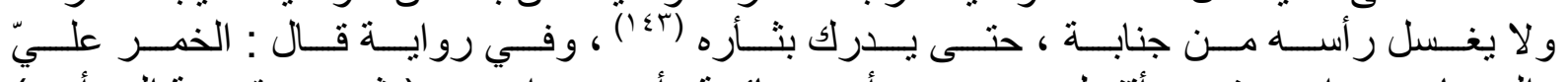

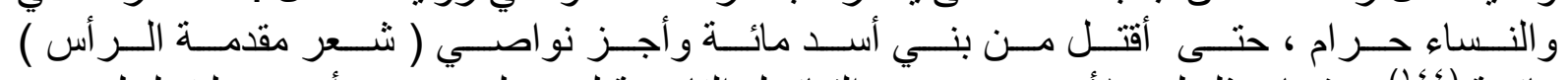

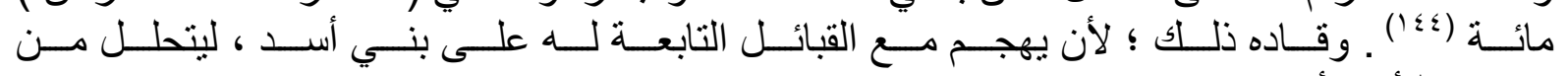
نذره ، بالثأر لأبيه . نان.

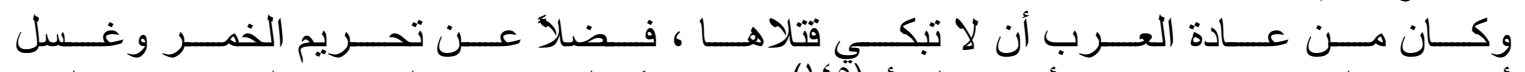

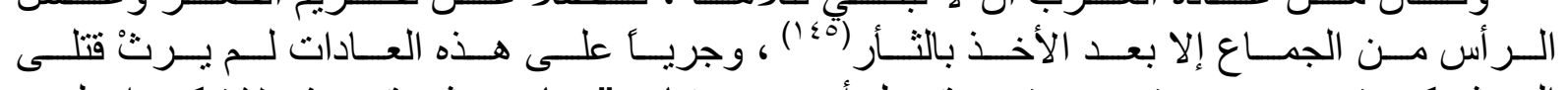

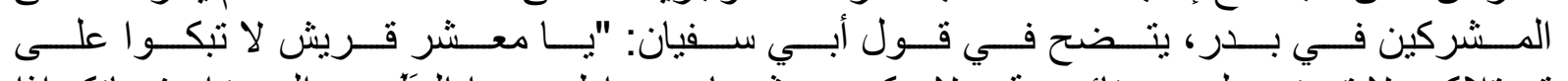

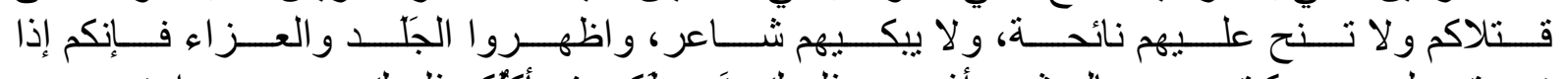

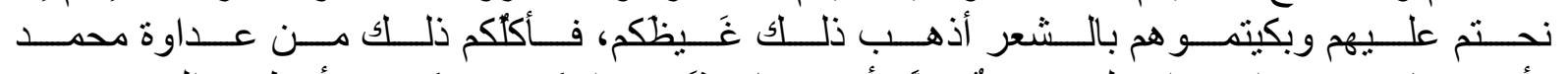

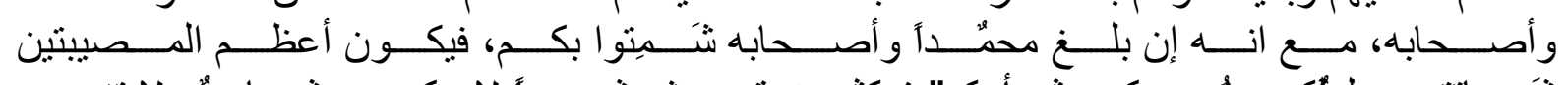

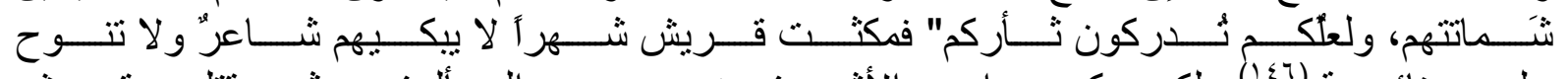

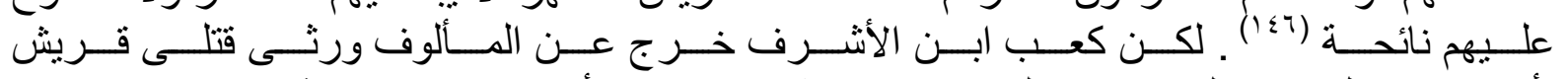

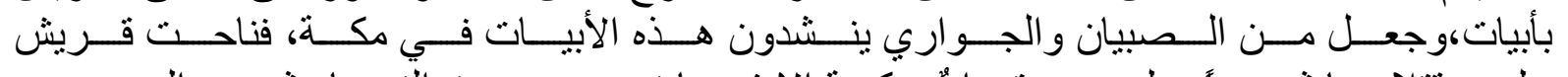

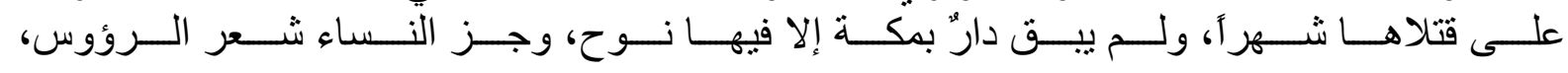

140

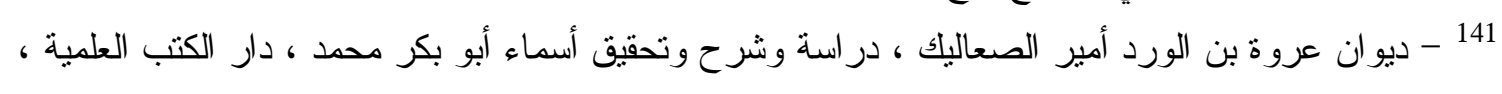

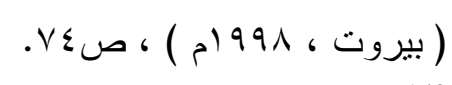

142

143

$$
144
$$

145

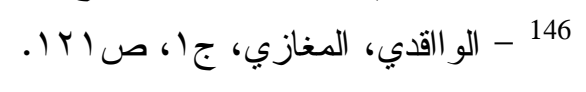




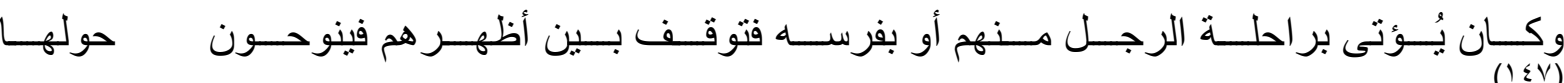

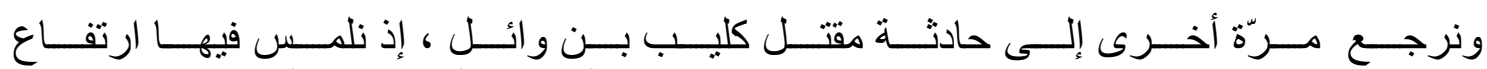

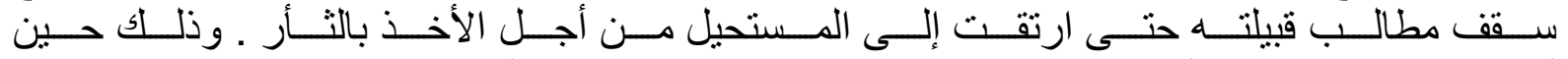

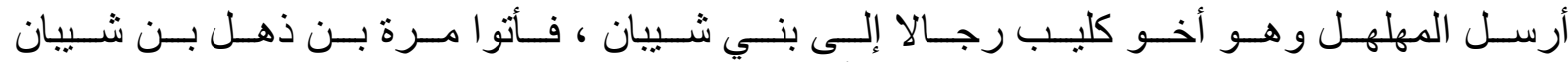

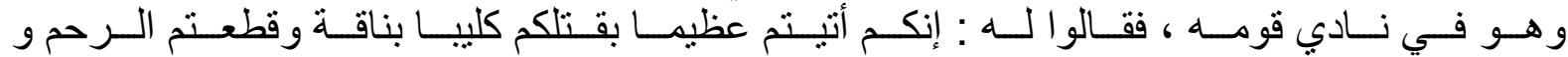

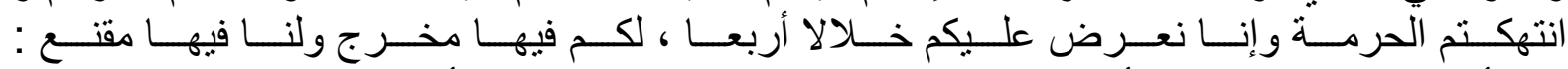

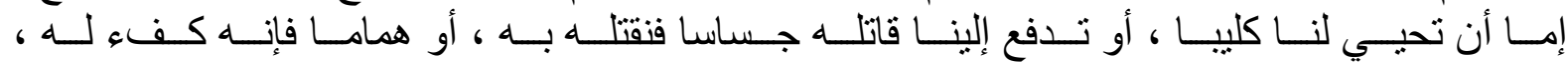

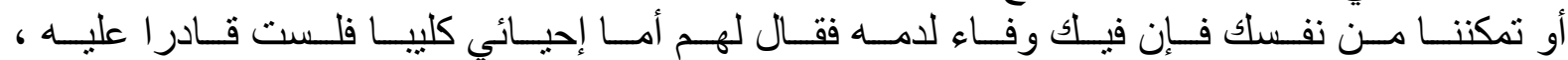

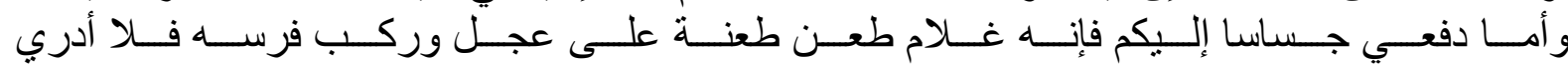

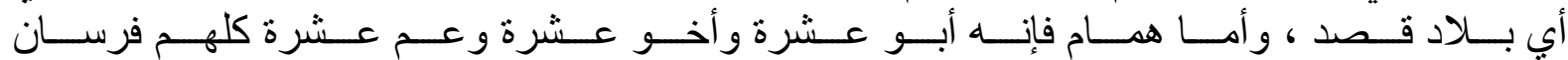

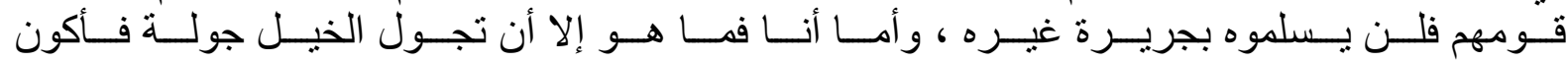

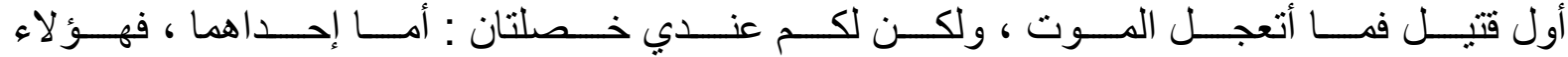

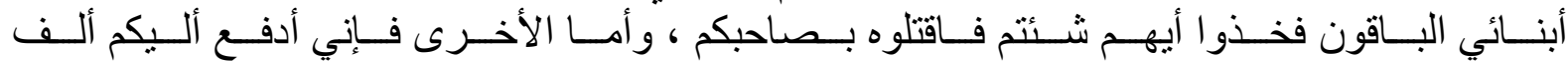

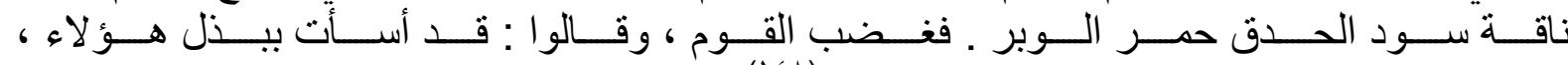

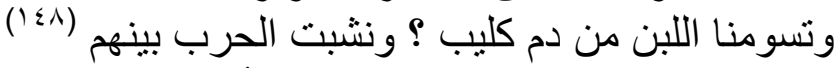

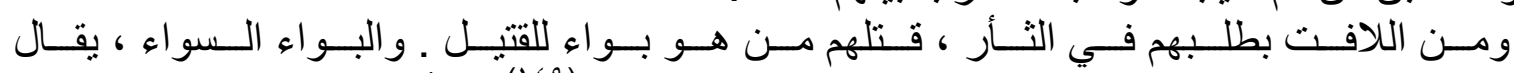

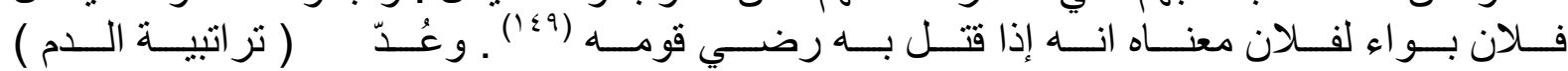

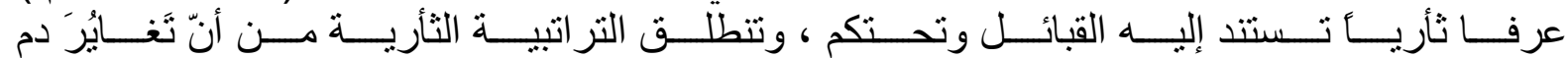

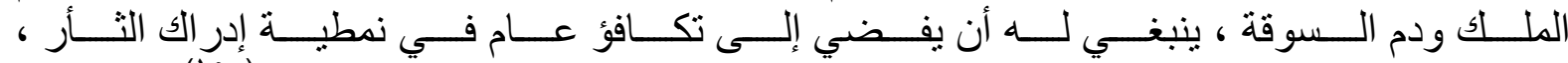

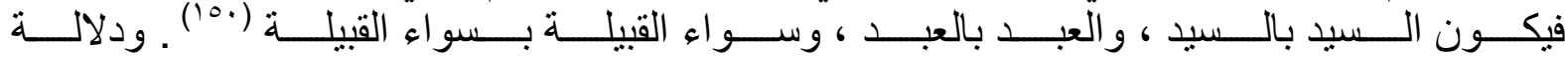

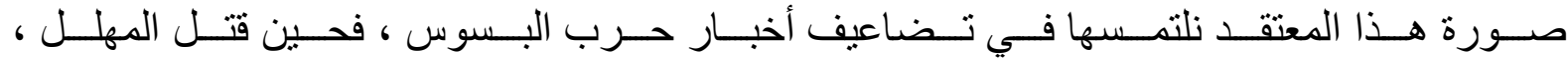

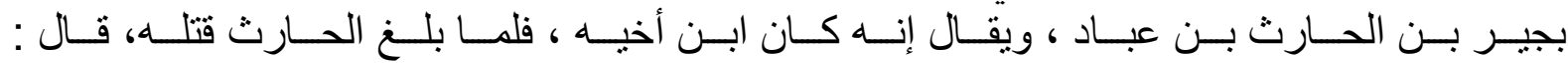

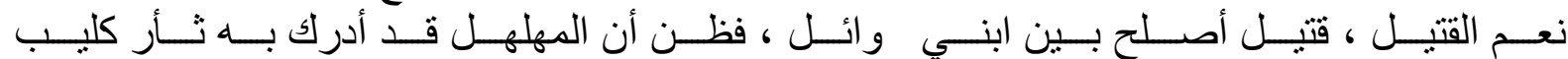

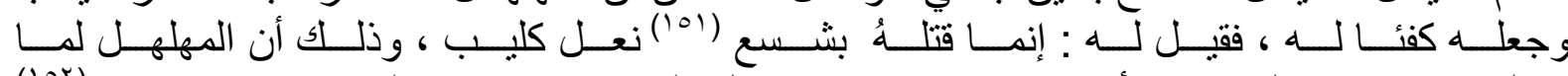

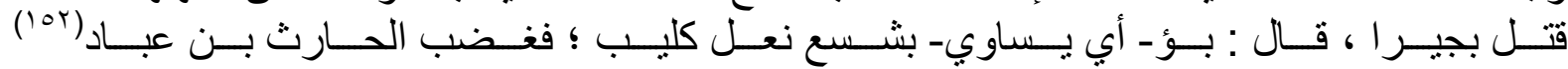

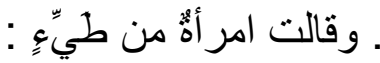

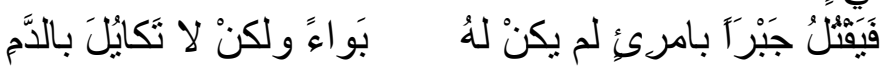

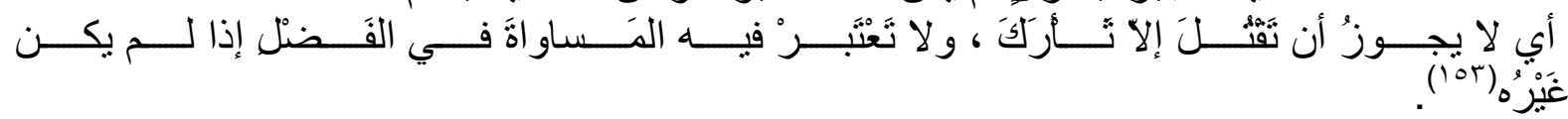

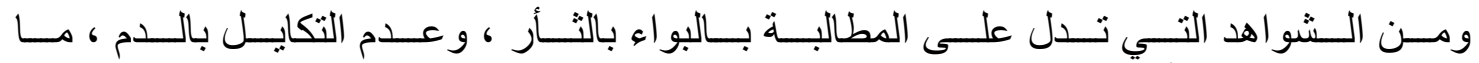

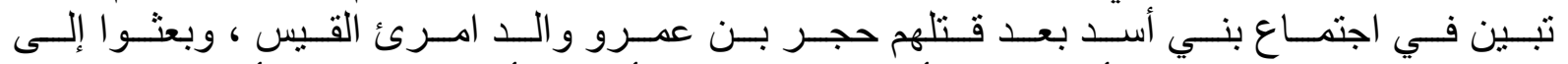

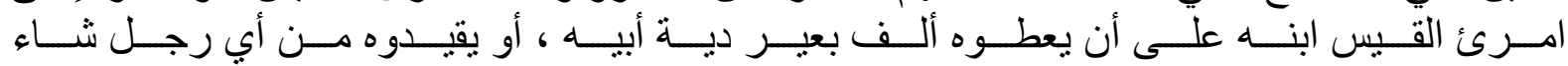

$$
147
$$

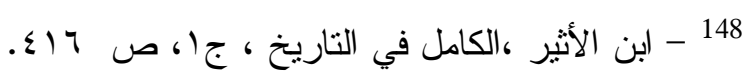
149

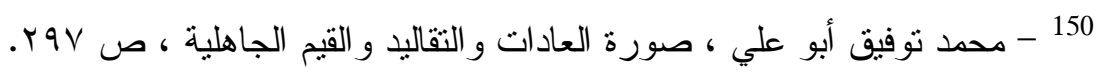
151

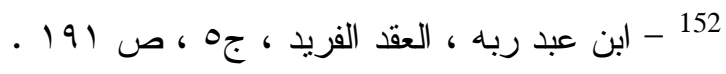

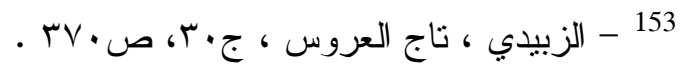




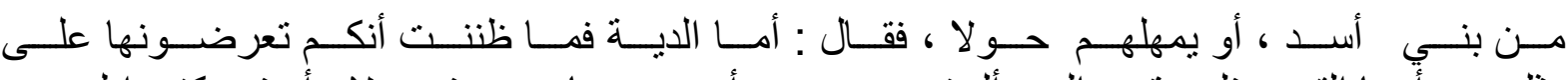

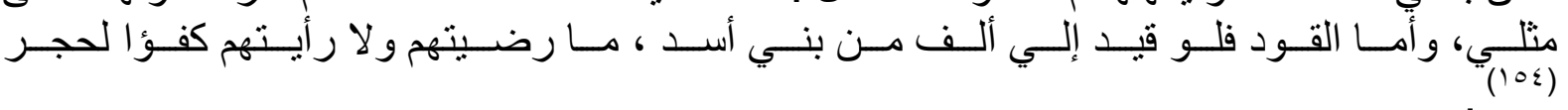

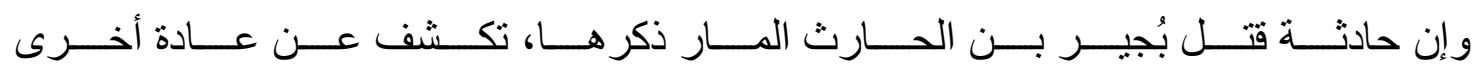

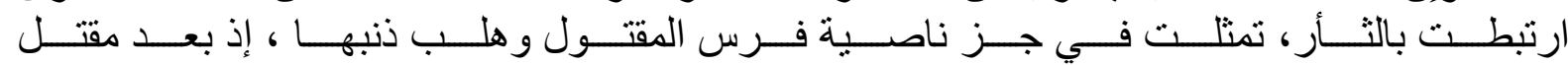

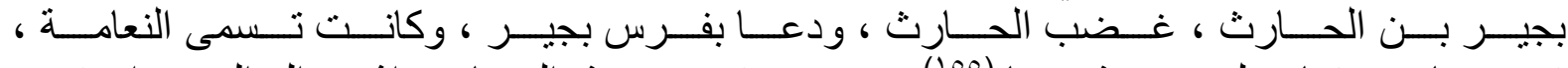

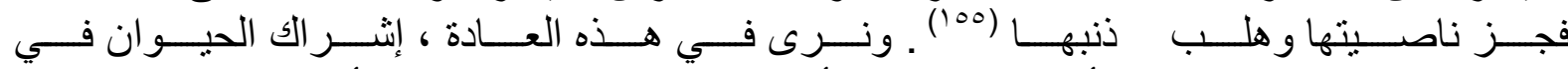

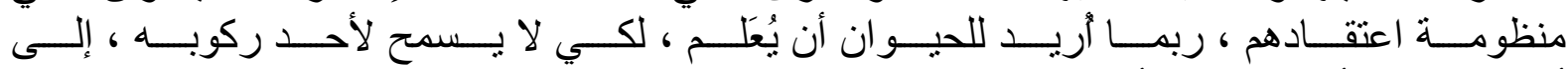

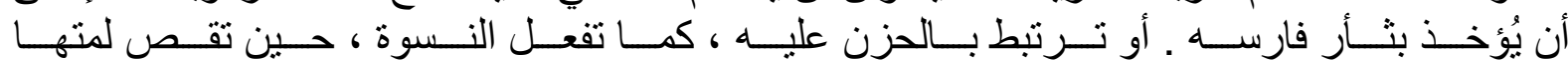

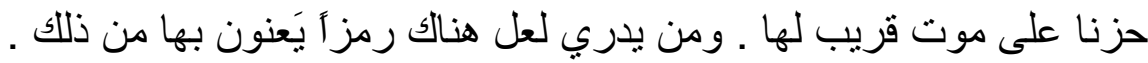

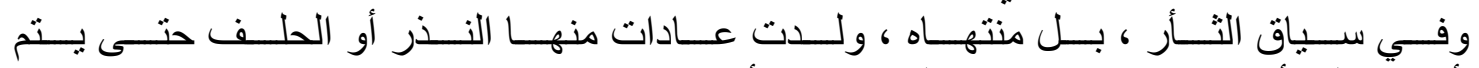

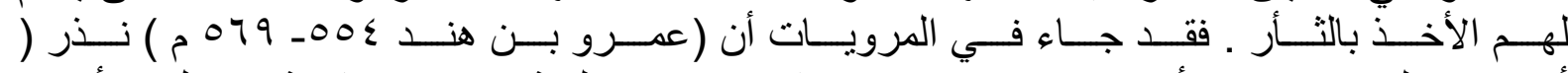

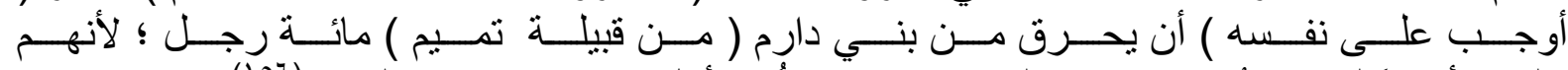

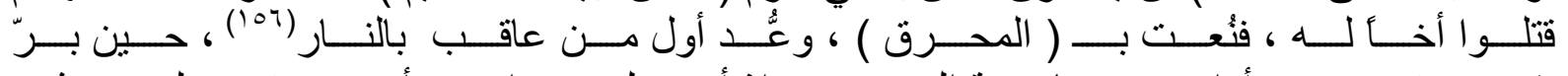

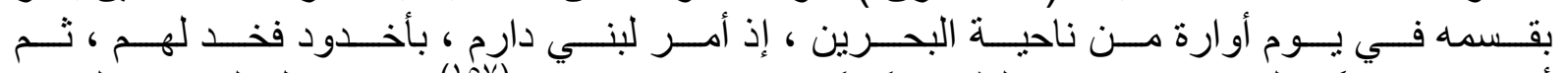

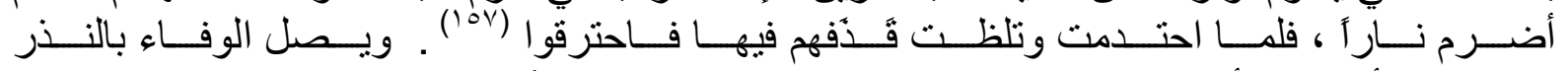

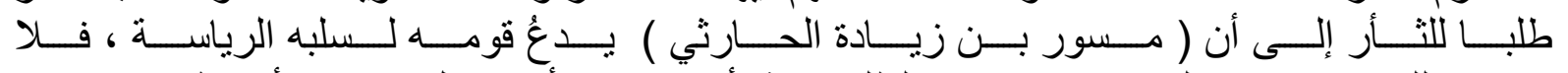

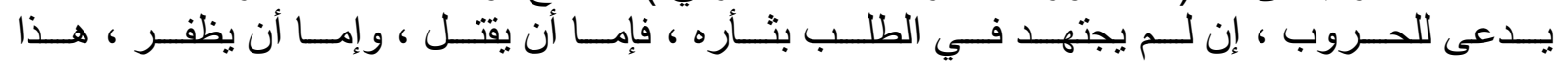

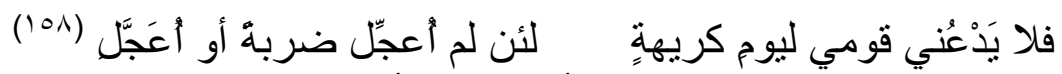

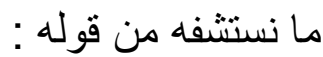

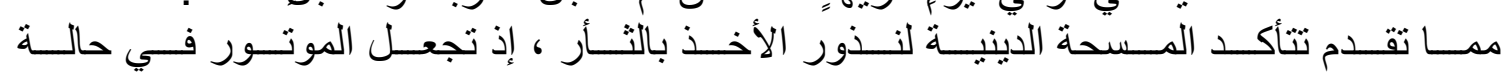

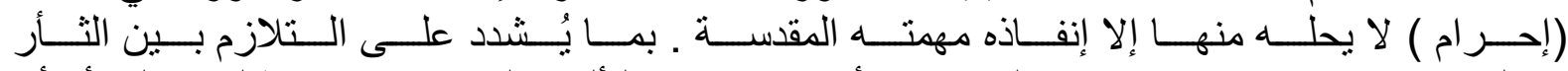

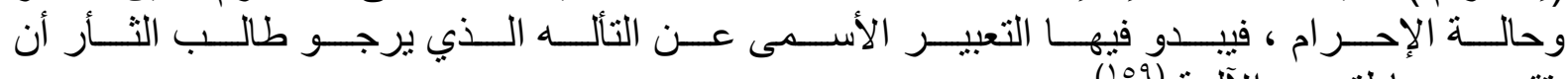

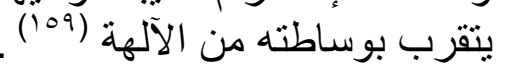

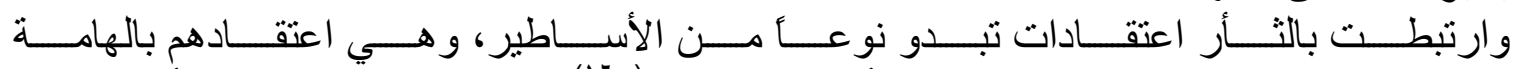

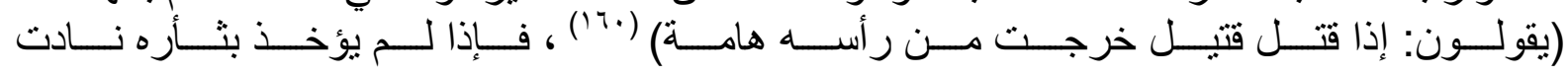

154

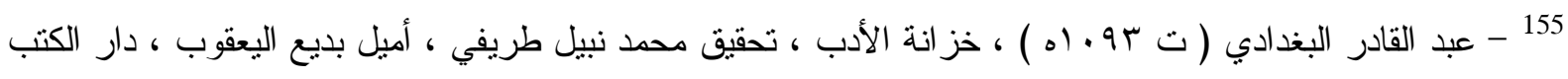

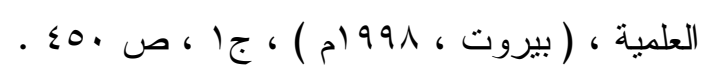

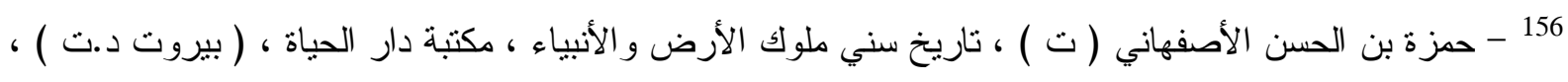

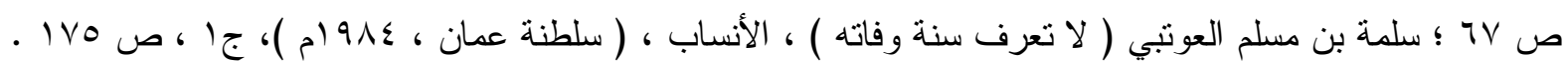
157 158 159 - ينظر : إحسان النص ، العصبية القبلية وأثز ها في الثعر الأموي ، دار اليقظة العربية ، ( بيروت ، ع 978 ام ) ، 


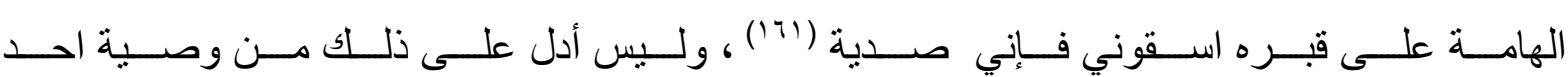

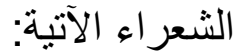

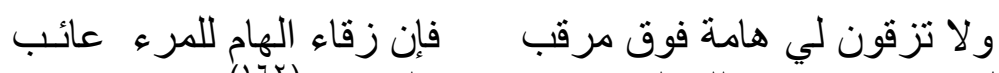

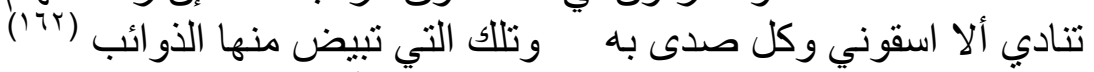

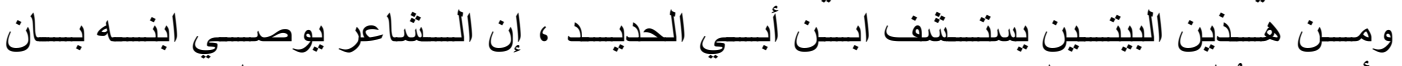

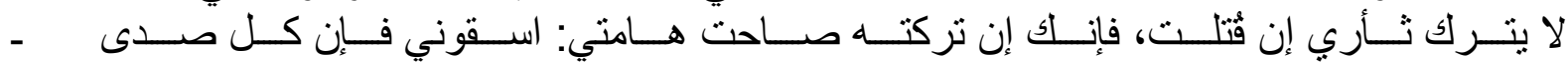

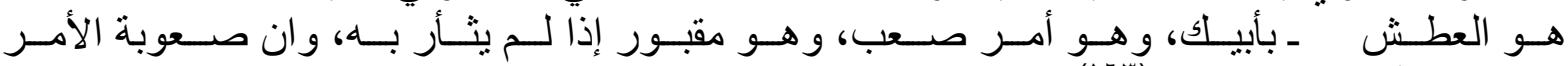

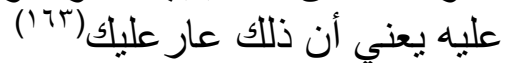

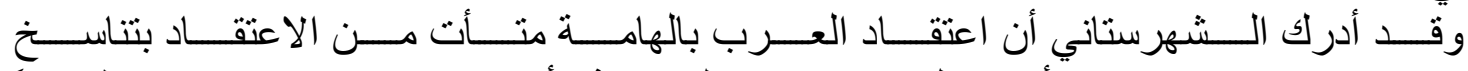

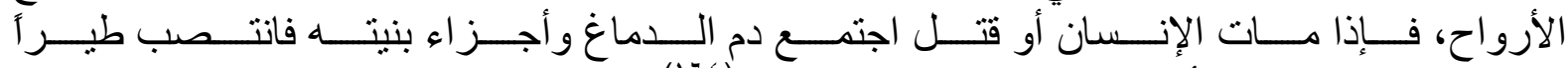

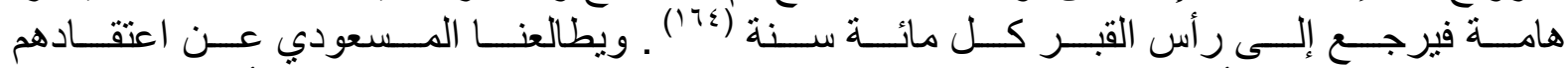

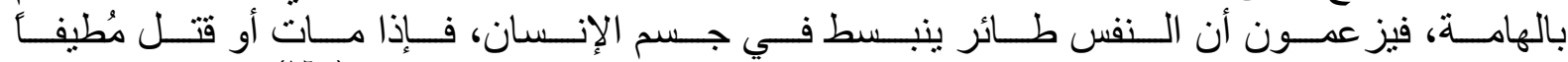

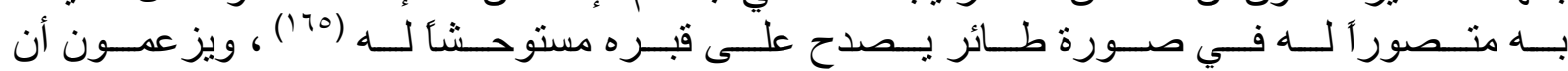

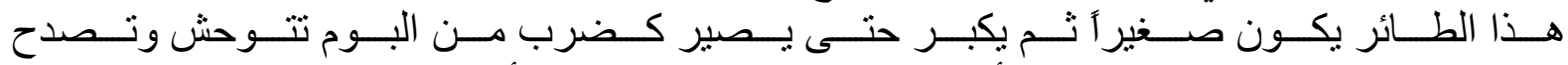

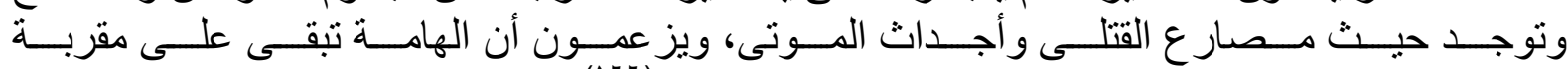

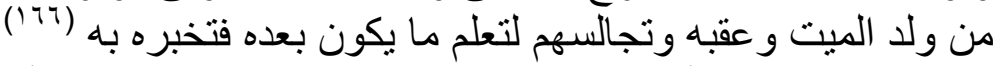

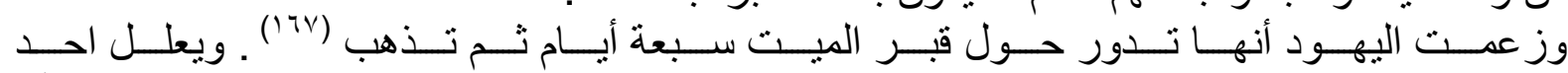

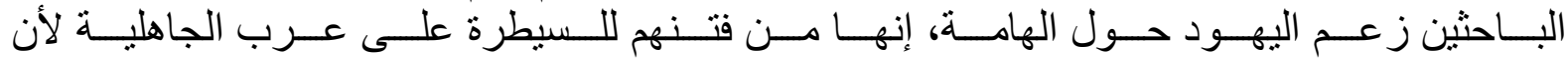

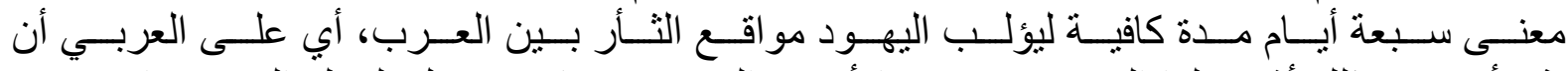

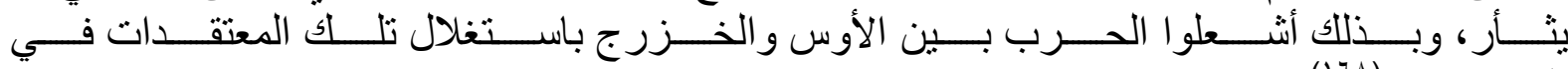

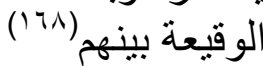

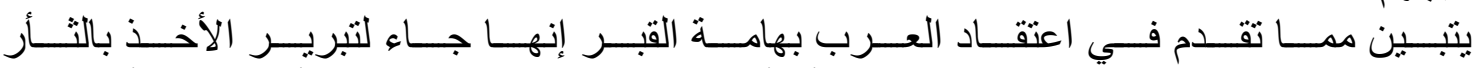

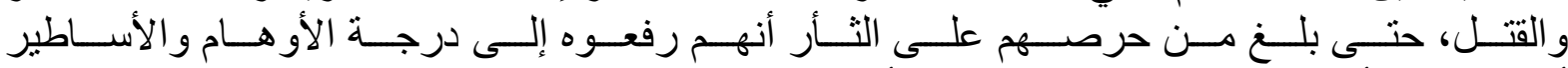

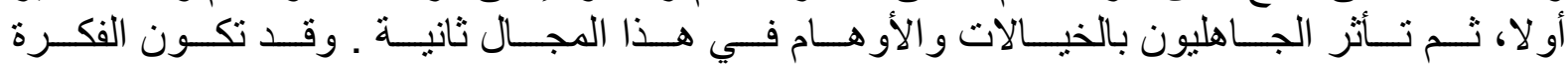

161

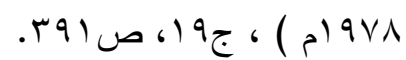
162 163

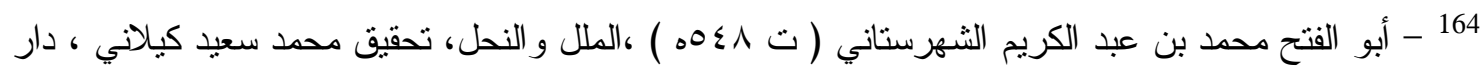

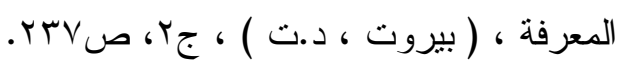

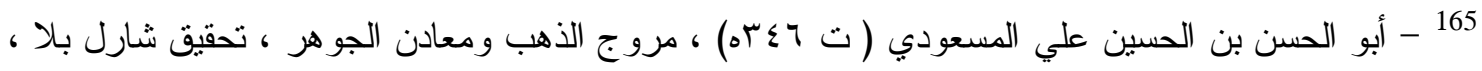

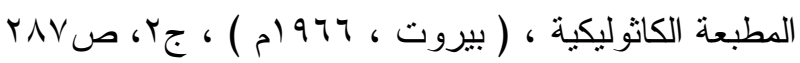
166

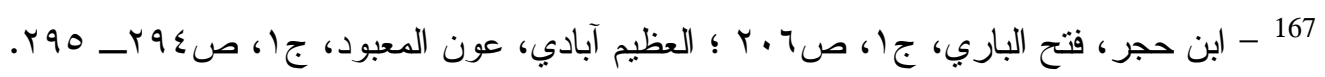

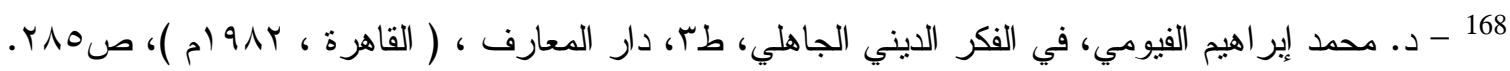




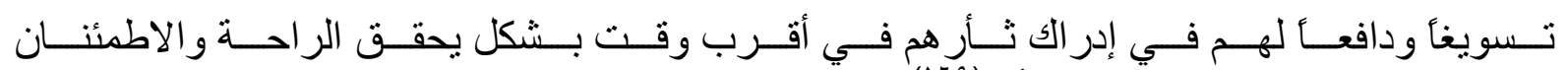

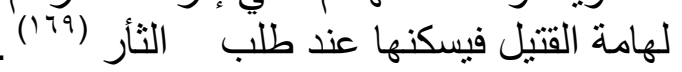

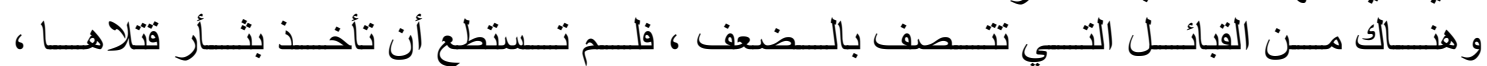

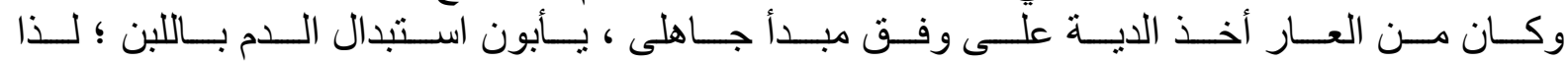

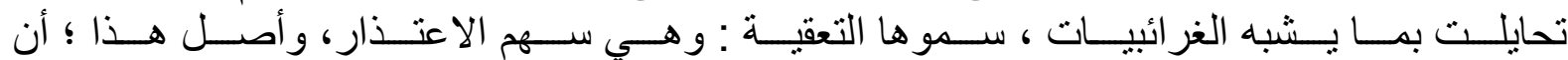

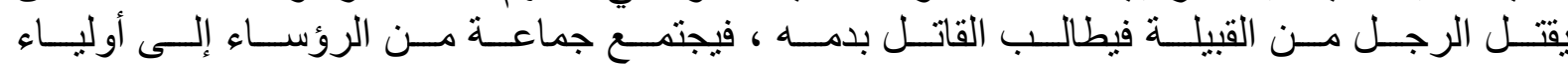

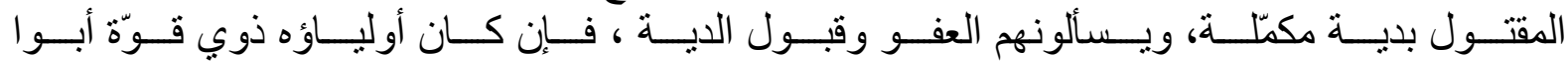

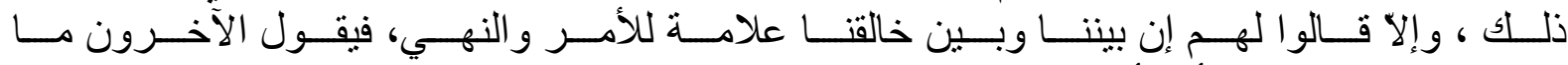

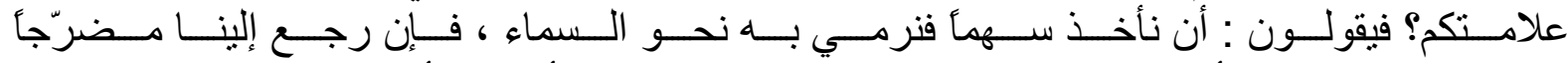

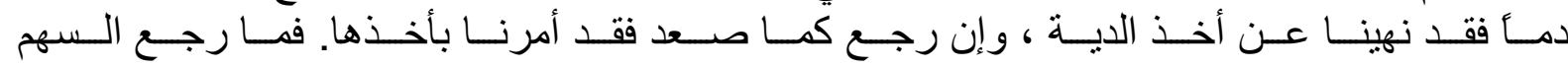

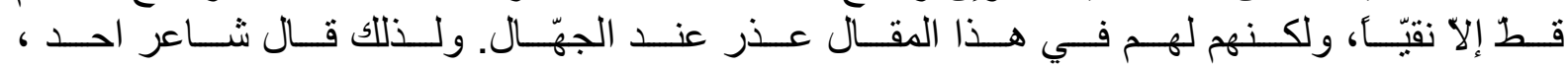
قبيل فعل هذا ، ولم يشاهده ولا لاهر رضيه :

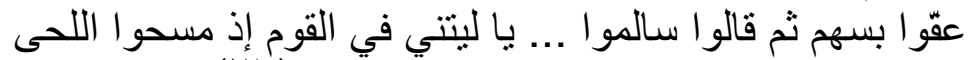

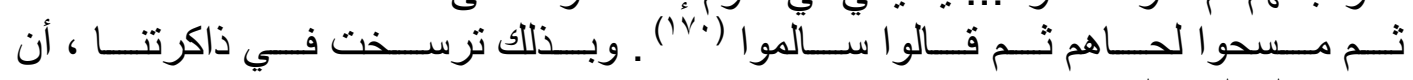

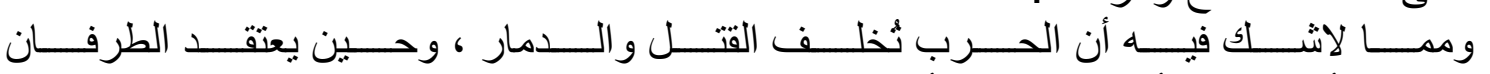

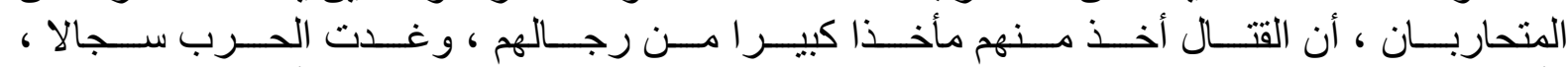

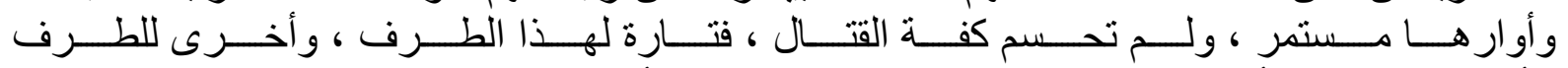

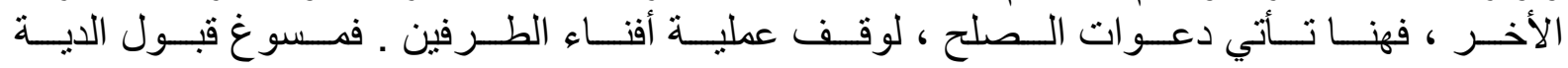

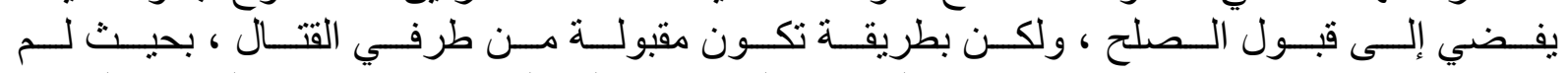

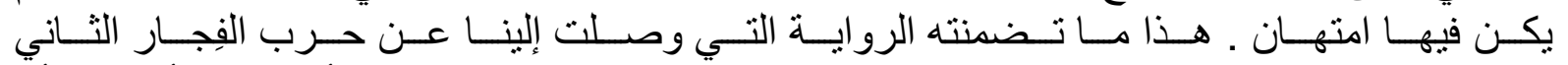

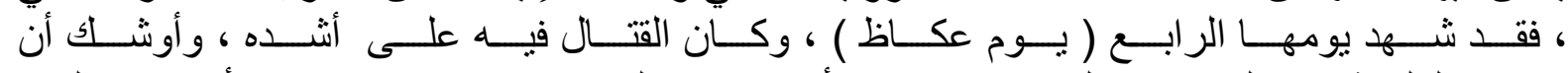

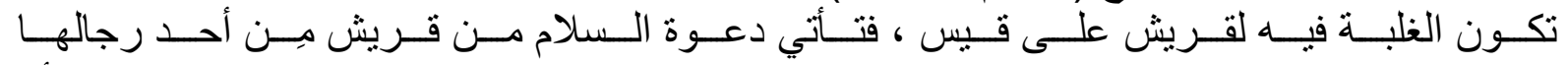

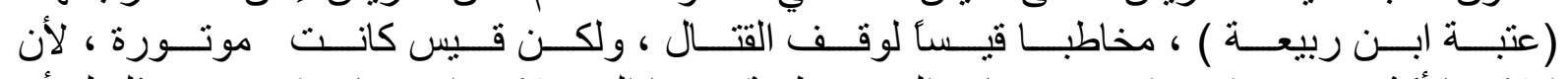

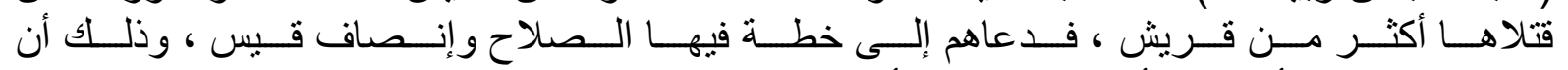

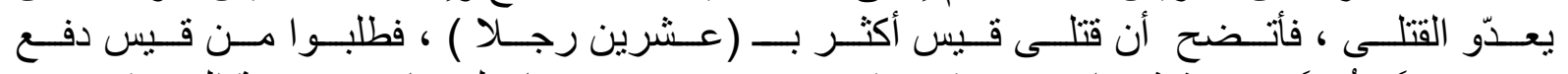

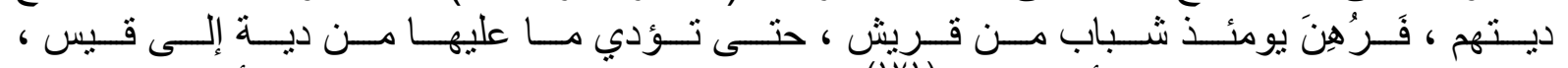

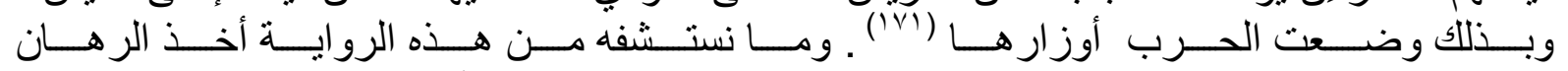

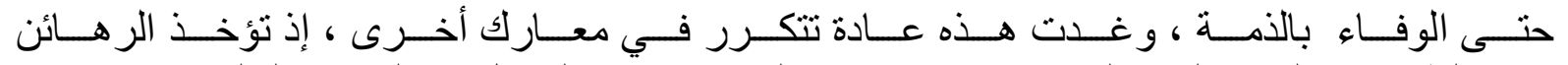

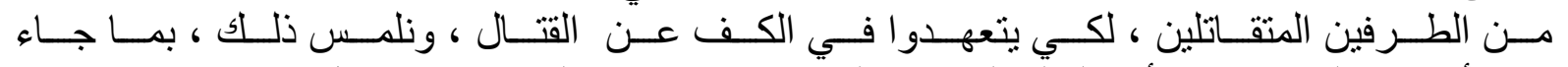

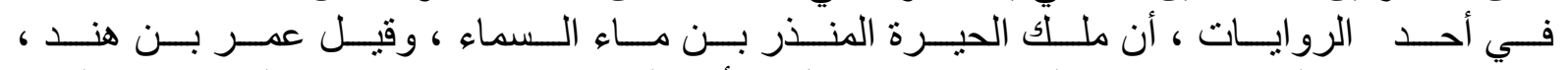

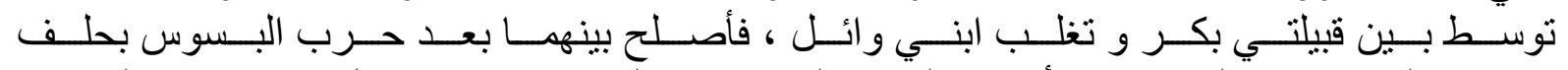

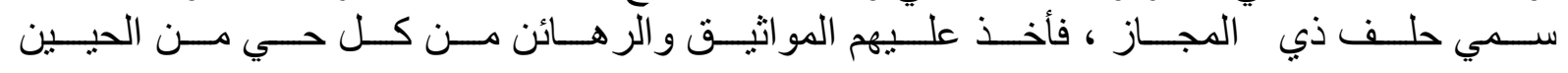

169 - بشرى محمد الخطيب، الرثاء في الثعر الجاهلي وصدر الإسلام، طبعة الإدارة المحلية ، ( بغداد ، 9VV ام ) ، صاءع.

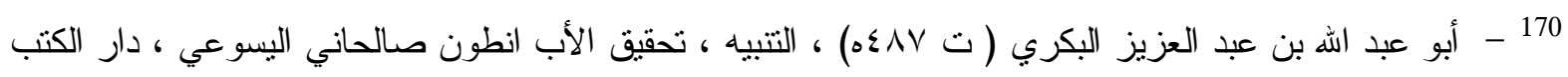

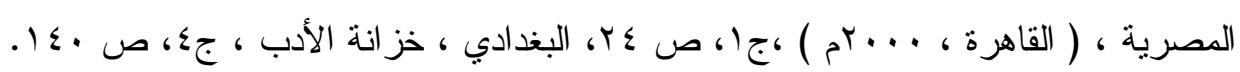
171 


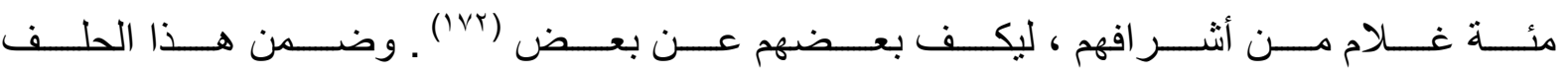

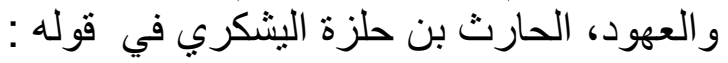

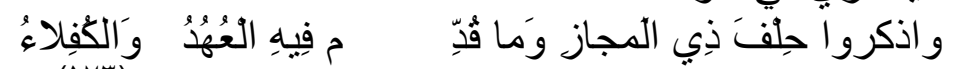

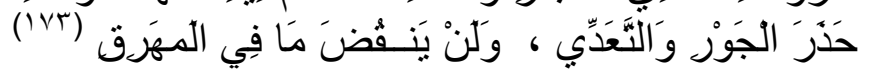

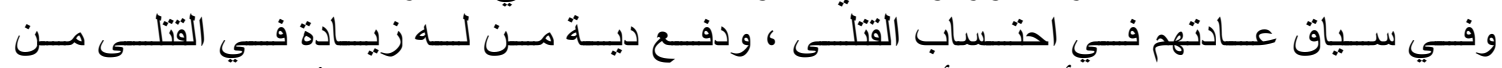

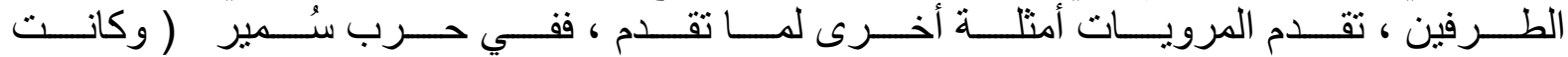

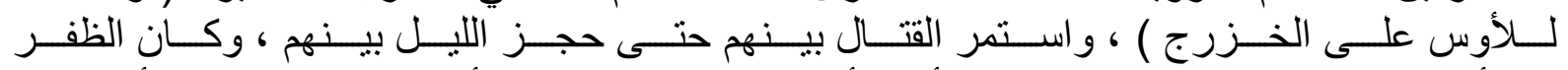

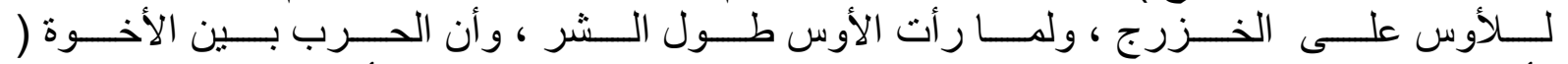

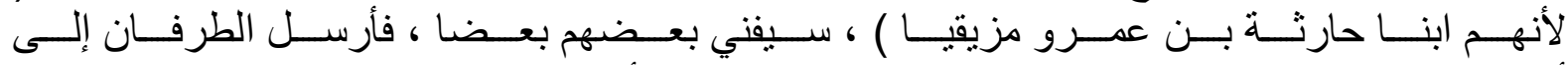

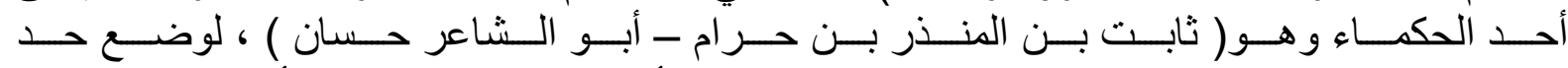

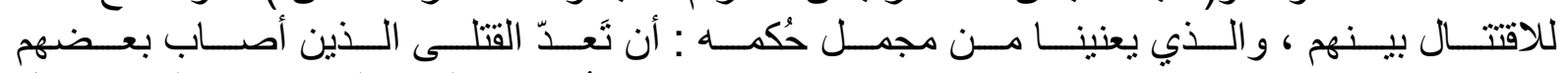

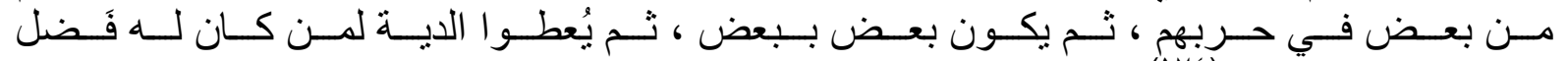
في القتلى من الفريقين (IY)

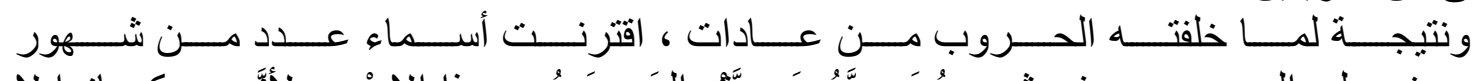

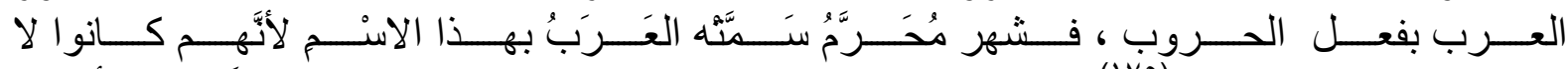

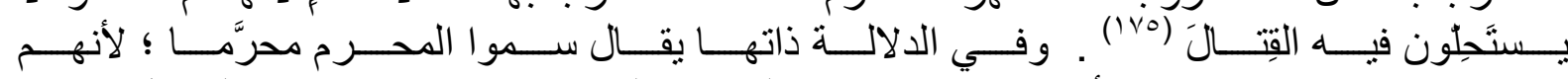

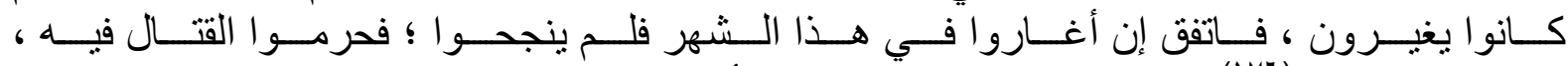

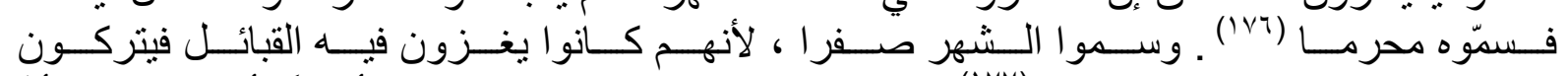

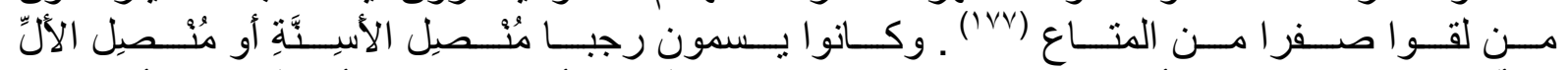

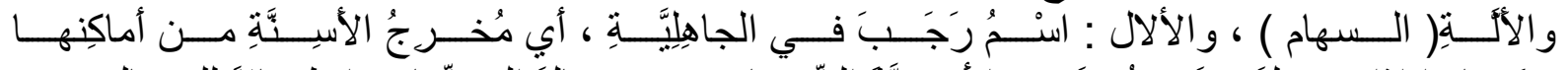

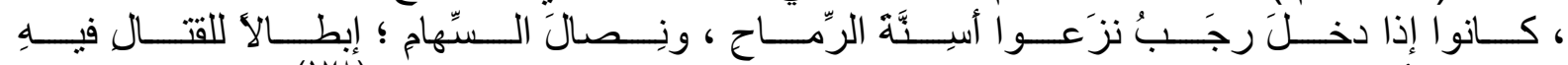

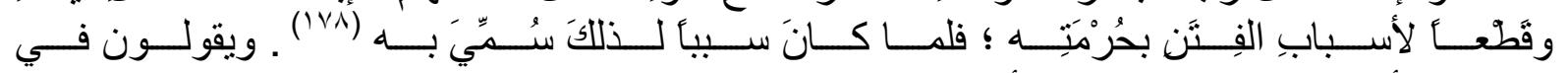

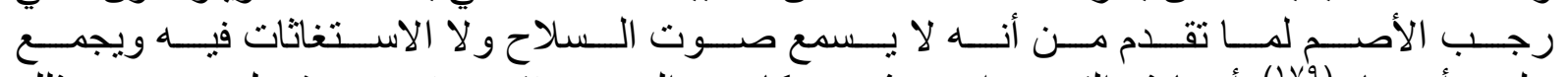

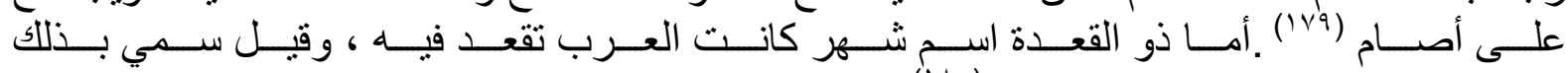

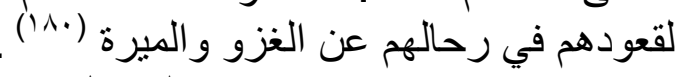

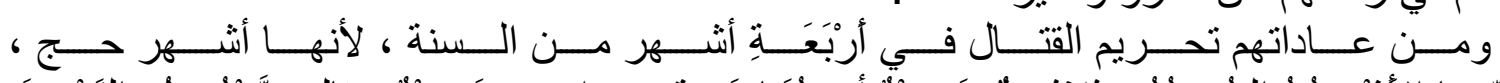

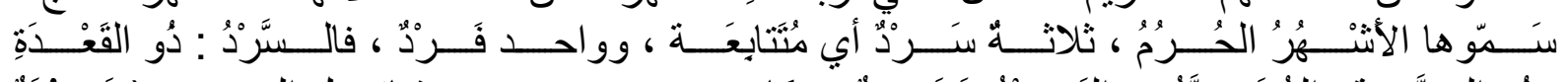

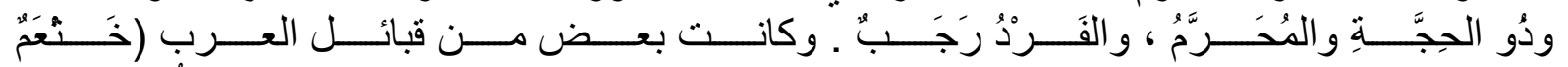

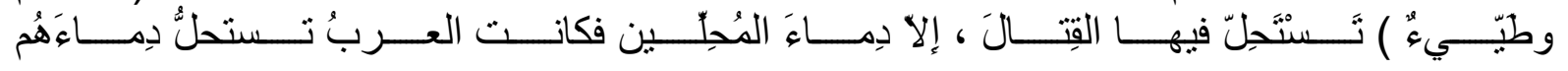

172

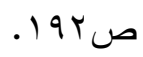

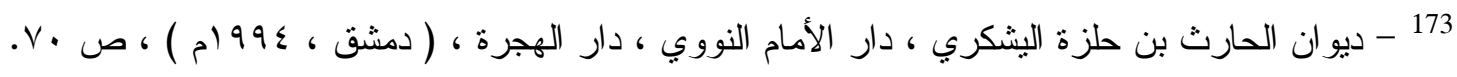
174 175

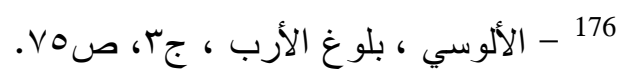

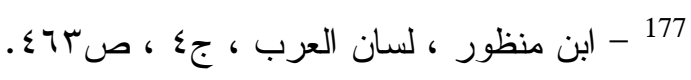

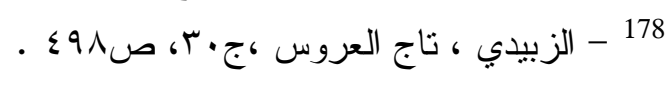

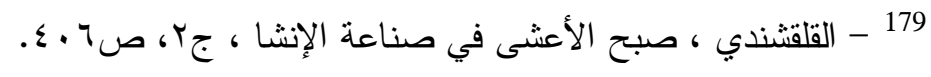

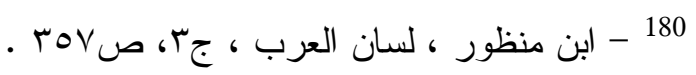




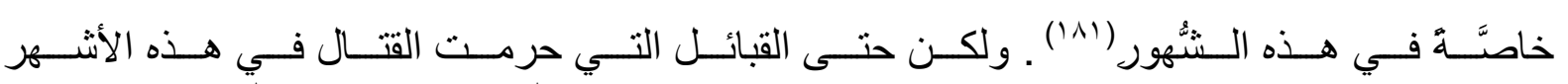

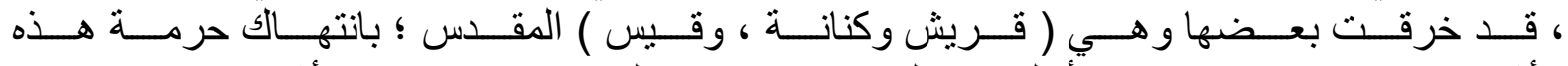

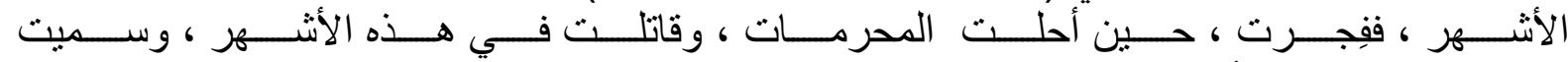

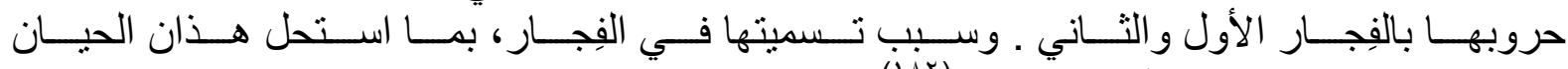

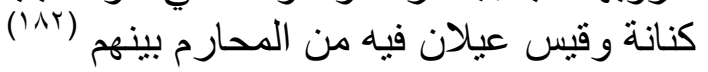

الخاتمة

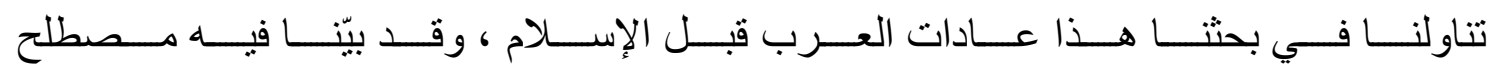

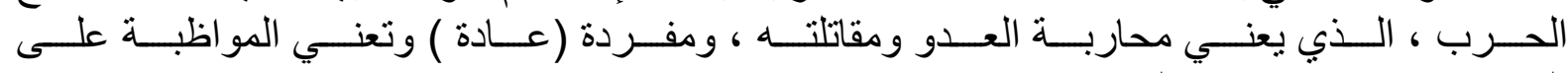

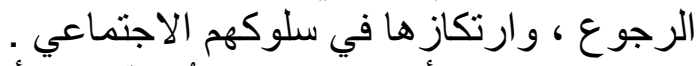

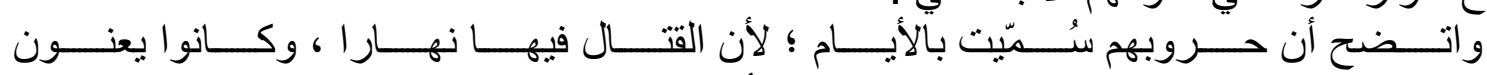

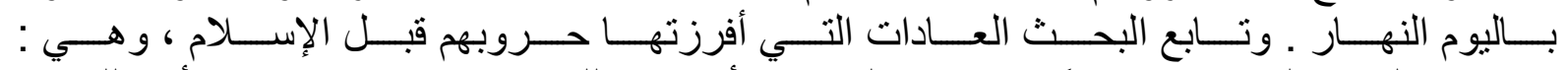

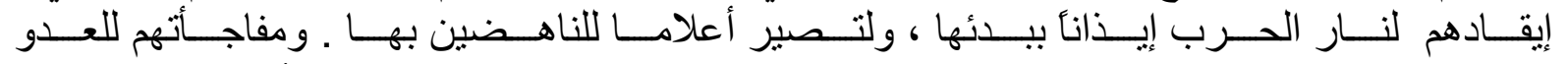

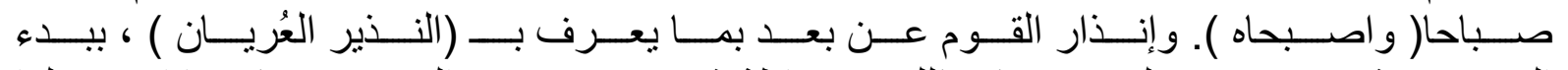

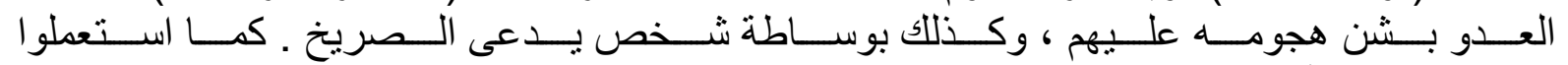

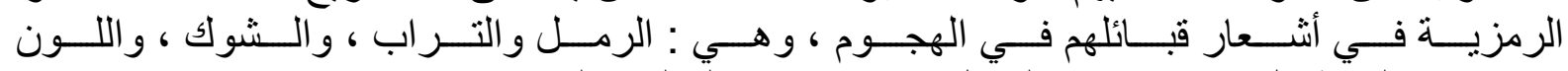

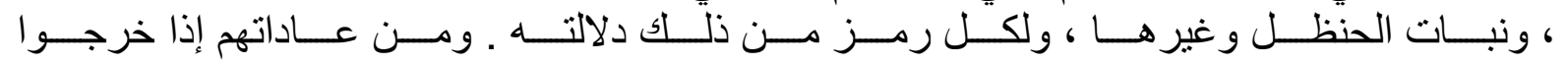

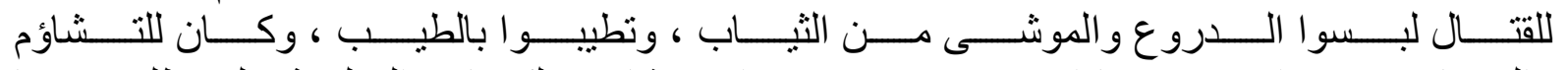

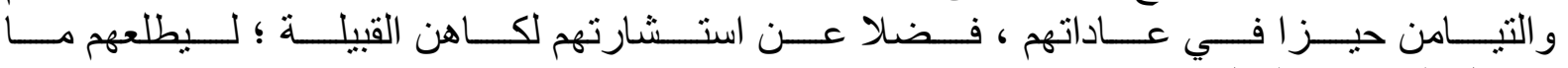
ستؤول إليه نتائج القتال .

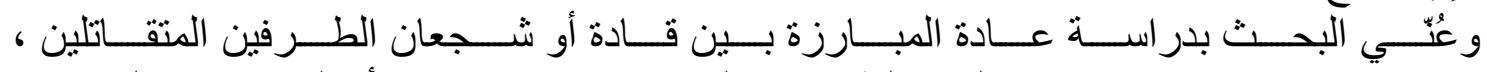

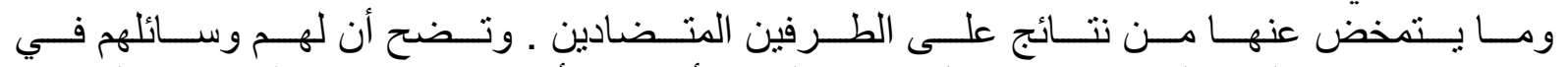

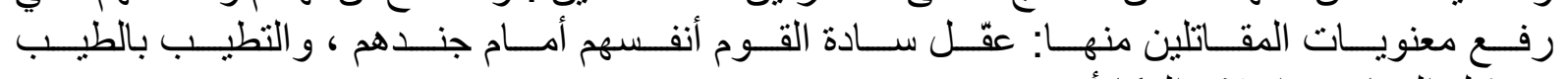
من قبل النساء ، و وإعلان المكافأة .

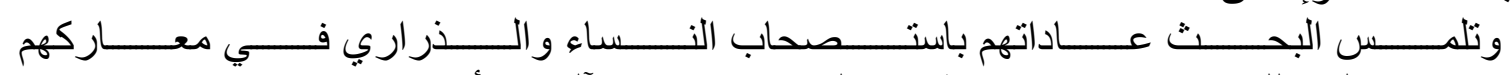

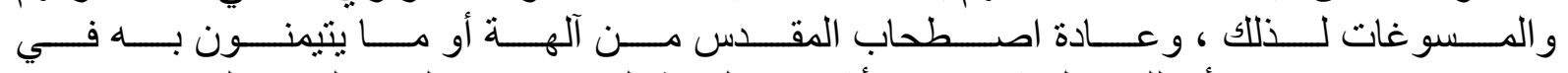

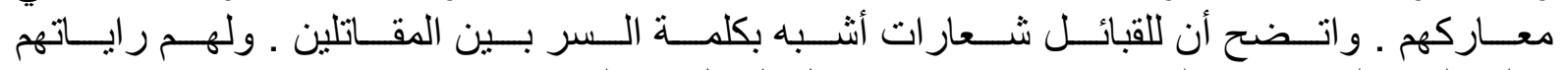

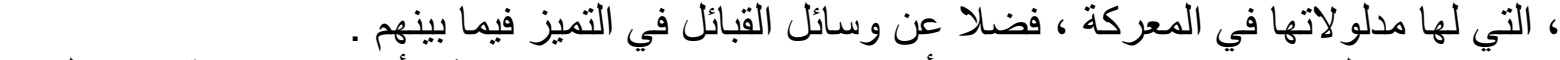

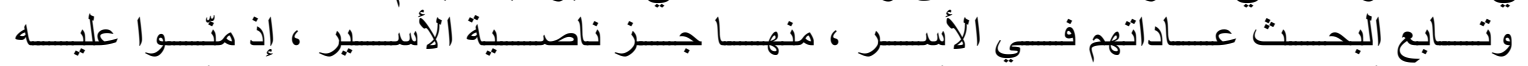

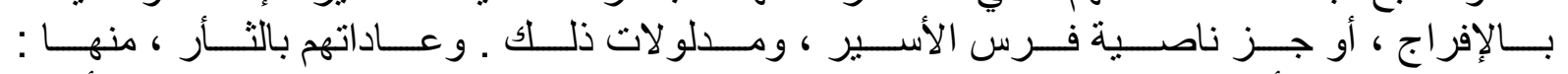

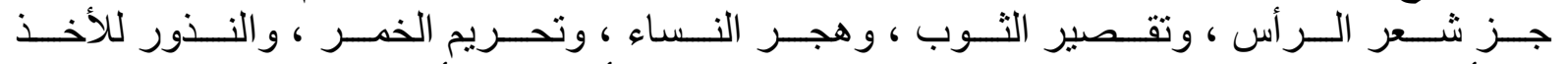

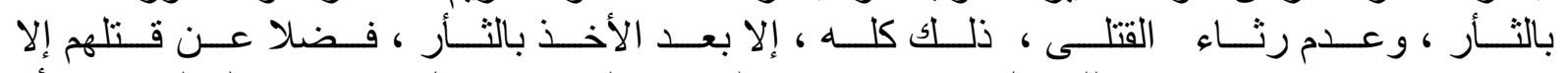

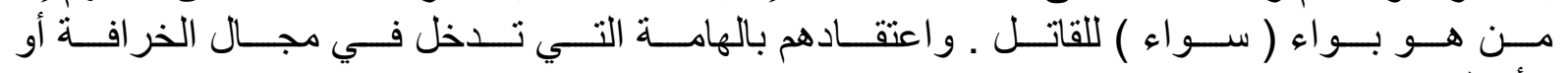

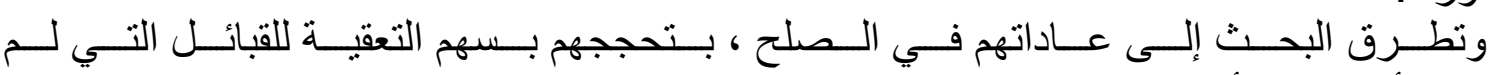

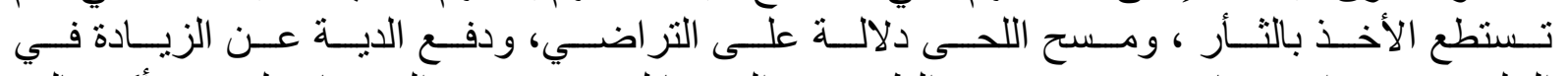

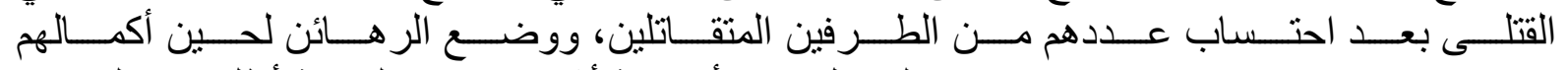

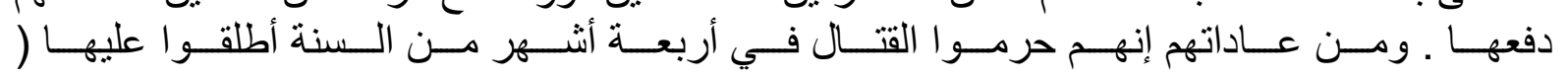

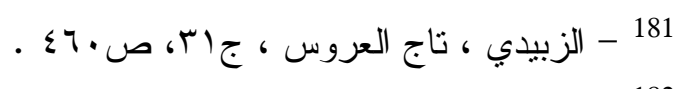
182 


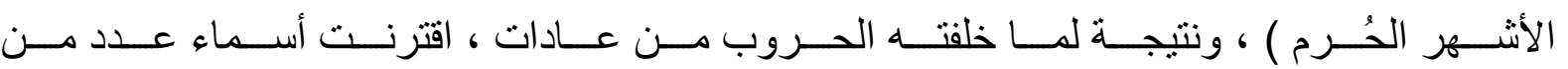

شهور العرب بفعل الحروب . 